\title{
The Incidence of Marine Toxins and the Associated Seafood Poisoning Episodes in the African Countries of the Indian Ocean and the Red Sea
}

\author{
Isidro José Tamele ${ }^{1,2,3} \mathbb{D}$, Marisa Silva ${ }^{1,4}$ and Vitor Vasconcelos ${ }^{1,4, * \mathbb{D}}$ \\ 1 CIIMAR/CIMAR - Interdisciplinary Center of Marine and Environmental Research, University of Porto, \\ Terminal de Cruzeiros do Porto, Avenida General Norton de Matos, 4450-238 Matosinhos, Portugal; \\ isitamele@gmail.com (I.J.T.); marisasilva17@gmail.com (M.S.) \\ 2 Institute of Biomedical Science Abel Salazar, University of Porto, R. Jorge de Viterbo Ferreira 228, \\ 4050-313 Porto, Portugal \\ 3 Department of Chemistry, Faculty of Sciences, Eduardo Mondlane University, Av. Julius Nyerere, n 3453, \\ Campus Principal, Maputo 257, Mozambique \\ 4 Department of Biology, Faculty of Sciences, University of Porto, Rua do Campo Alegre, \\ 4619-007 Porto, Portugal \\ * Correspondence: vmvascon@fc.up.pt; Tel.: +35-122-340-1817; Fax: +35-122-339-0608
}

Received: 27 November 2018; Accepted: 10 January 2019; Published: 21 January 2019

\begin{abstract}
The occurrence of Harmful Algal Blooms (HABs) and bacteria can be one of the great threats to public health due to their ability to produce marine toxins (MTs). The most reported MTs include paralytic shellfish toxins (PSTs), amnesic shellfish toxins (ASTs), diarrheic shellfish toxins (DSTs), cyclic imines (CIs), ciguatoxins (CTXs), azaspiracids (AZTs), palytoxin (PITXs), tetrodotoxins (TTXs) and their analogs, some of them leading to fatal outcomes. MTs have been reported in several marine organisms causing human poisoning incidents since these organisms constitute the food basis of coastal human populations. In African countries of the Indian Ocean and the Red Sea, to date, only South Africa has a specific monitoring program for MTs and some other countries count only with respect to centers of seafood poisoning control. Therefore, the aim of this review is to evaluate the occurrence of MTs and associated poisoning episodes as a contribution to public health and monitoring programs as an MT risk assessment tool for this geographic region.
\end{abstract}

Keywords: Indian Ocean; marine toxins; harmful algal bloom

Key Contribution: The scarcity of MT data along African countries of the Indian Ocean and the Red Sea suggests the need for further studies and the creation of specific monitoring programs of MTs, particularly for dinoflagellates and diatoms since these constitute the phytoplankton that produces fatal MTs.

\section{Introduction}

The occurrence of Harmful Algal Blooms (HABs) in marine ecosystems can be one of the great threats to public health due to their capacity to produce marine toxins (MTs) as secondary metabolites [1-14]. MTs can be accumulated by distinct marine organisms such as fish, mollusks and crustaceans [15-24] which are the basic diet of coastal human populations. Suspected or confirmed episodes of human poisoning caused by MTs have been reported worldwide in the last century $[20,21,25-48]$. The occurrence of episodes of human poisoning occurs via ingestion of contaminated marine food due to the lack of monitoring programs in some countries or violations of national health authorities' regulations imposing the closure of harvesting areas and 
seafoodcommercialization [18,20,26,35,39,45,47,49]. Despite the ideal environmental conditions for theformation of blooms in this geographical area, there are insufficient data related to their occurrence and toxin production [50]. This review analyses the occurrence of MTs and their producers along the African Indian and the Red Sea coasts (from Egypt to South Africa) and associated human poisoning episodes. The existence of monitoring programs of MTs will be also highlighted and finally, some suggestions for the control and prevention of marine toxins in this area will be presented.

\section{Marine Toxins and Their Producers}

Chemically, toxins can be grouped according to their polarity, lipophilic and hydrophilic. Concerning MT monitoring, analysis and quantification methods in seafood are described in Table 1 , including bioassays, immunoassays, and analytical chemistry methods. The bioassay methods (Mouse Bioassay (MBA), Rat Bioassay (RBA)) are no longer in use due to ethical reasons according to Directive 86/609/EEC [51] and procedural variation [52] (e.g., use of different extraction solvents and consequently shortcomings). Chemical methods, mainly liquid chromatography coupled to mass spectrometry, are considered as the most promising since they are fully validated and standardized to replace bioassays in many organizations worldwide. Further information related to each toxin group such as syndromes, producers, common vectors, symptoms, detections methods in seafood, limit of detection (LOD) and quantification (LOQ) and permitted limit used in some parts of the world is also described in Table 1.

\subsection{Lipophilic Toxins}

Lipophilic toxins are lipid soluble toxins and this group comprises okadaic acid (OA), ciguatoxins (CTX), cyclic imines (CIs) [spirolides (SPXs), gymnodimines (GYMs), pinnatoxins (PnTXs) and pteriatoxins (PtTXs)], brevetoxins (PbTxs), pectenotoxins (PTXs), yessotoxins (YTXs) and azaspiracids [AZAs], Table 1.

\subsubsection{Okadaic Acid and Analogs}

Okadaic acid (OA)and their analogs, dinophysistoxins-1, -2 and -3 (DTXs) (Figure 1), are polyethers produced by dinoflagellates: Prorocentrum spp. [8], Dinophysis spp. [2,6,9,10,15,53,54] and Phalacroma rotundatum [55] (Table 1).These polyethers are frost-resistant and heat-stable and consequently, their toxicity is not affected by the cooking procedures in water (they are stable at $<150{ }^{\circ} \mathrm{C}$ ) [56]. The OA group is responsible for the diarrheic shellfish poisoning syndrome (DSP), with OA being the main representative of DSP toxins. Okadaic acid (OA)and its analogs act as inhibitors of the serine/threonine phosphoprotein phosphatases $1,22 \mathrm{~B}, 4,5$ types $[57,58]$.

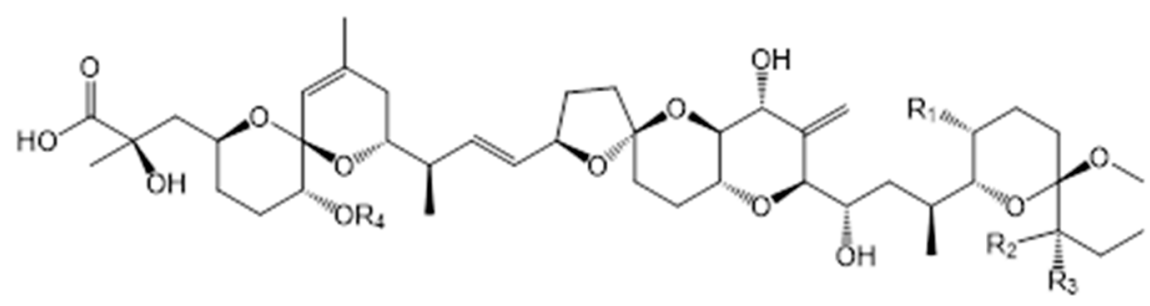

\begin{tabular}{ccccc}
\hline Analog & $\mathbf{R}_{1}$ & $\mathbf{R}_{2}$ & $\mathbf{R}_{3}$ & $\mathbf{R}_{4}$ \\
\hline OA & $\mathrm{CH}_{3}$ & $\mathrm{H}$ & $\mathrm{H}$ & $\mathrm{H}$ \\
DTX1 & $\mathrm{CH}_{3}$ & $\mathrm{CH}_{3}$ & $\mathrm{H}$ & $\mathrm{H}$ \\
DTX2 & $\mathrm{H}$ & $\mathrm{H}$ & $\mathrm{CH}_{3}$ & $\mathrm{H}$ \\
DTX3 & $\mathrm{H} / \mathrm{CH}_{3}$ & $\mathrm{H} / \mathrm{CH}_{3}$ & $\mathrm{H} / \mathrm{CH}_{3}$ & Acyl \\
\hline
\end{tabular}

Figure 1. Chemical structure of OA and main derivatives [DTX1, DTX2, and DTX3]. 


\subsubsection{Ciguatoxins}

Ciguatoxins (CTXs) (Figure 2A) are a group of toxins produced by tropical and subtropical dinoflagellates species: Gambierdiscus toxicus and Fukuyoa spp. [59,60] (Table 1) mainly found in the Pacific, Caribbean and the Indian Ocean regions [P-CTX, C-CTX and I-CTX, respectively]. CTXs are lipid-soluble polyethers with 13-14 rings fused by ether linkages into a rigid ladder-like structure [60]. To date, the structures of20 P-CTXs, 10 C-CTXSand 4 I-CTXs analogs have been fully identified and the most reported include P-CTX-1, P-CTX-2, P-CTX-3, P-CTX-3C [61-67], gambiertoxin [GbTXs, namely, P-CTX-4A and P-CTX-4B] [68], C-CTX-1, C-CTX-2 [67,69], I-CTX-1, I-CTX-2, I-CTX-3 and I-CTX-4 [70,71] mostly in predatory fish and gastropods $[20,21,23,66,69,72-74]$. The major analog of each group of CTXsis P-CTX-1. C-CTX-1, C-CTX-2, I-CTX1, and I-CTX-2. The chemical structure of the last two (I-CTXs) have the same molecular weight and similar structures as C-CTX-1 [62,67,70,71]. CTXs are odorless and tasteless heat-stable molecules and are not affected when subjected to water cooking, freezing and acid or basic conditions, though they suffer structural alterations by oxidation [60]. CTXs and Maitotoxin (MTX) (Figure 2B) (produced by Gambierdiscus spp. [68]) were the first group of toxins reported to be responsible for ciguatera shellfish poisoning (CFP) [23]. The mechanism of action of CTX and analogs is to elevate calcium ion concentration and activate non-selective cation channels in cells causing neurologic effects in humans [75].

\subsubsection{Cyclic Imines}

Cyclic imines (CI) (Figure 3) are toxins produced by dinoflagellates: SPXs: Alexandrium spp. [1,76], GYMs: Gymnodium spp. [77], PnTXs: Vulcanodinium rugosum [78] and PtTXs: biotransformation from PnTXs via metabolic and hydrolytic transformation in shellfish [1,5,77-79] (Table 1). CIs are a heterogenous group composed ofspirolides (SPXs), gymnodimines (GYMs), pinnatoxins (PnTXs) and pteriatoxins (PtTXs) and more than 24 structural analogs have been described to date [80].

Regarding chemical properties, these toxins are a group of macrocyclic compounds that have in common an imine functional group and spiro-linked ether moieties in their structure [80]. They are colorless amorphous solid macrocyclic compounds with imine and spiro-linked ether moieties [80], considerably soluble in organic solvents such as methanol, acetone, chloroform and ethyl acetate $[5,80]$. CIs are neurotoxins and actby inhibiting the nicotinic and muscarinic acetylcholine receptors (mAChR and $\mathrm{nAChR}$, respectively) in the nervous system and at the neuromuscular junction [81]. CI bioactivity seems to depend on the imine functional group since the hydrolysis of spirolides A-D produce spirolide $\mathrm{E}$ and $\mathrm{F}$ with a keto-amine structure that is fully inactive [81]. To date, there are no regulations for CIs and no common symptoms can be recognized [82]. 


(b)

(c)

$$
\mathrm{COH}^{\mathrm{O}}
$$

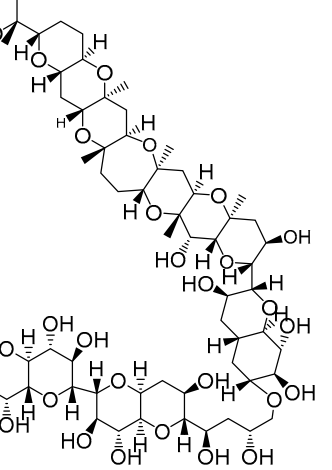

Figure 2. Chemical structure of major CTXs analogs from Pacific (P-CTXs) (a) and Caribbean (C-CTXs) (b) regions. The major CTXs from Indian region (I-CTXs) have a similar structure with C-CTX-1. (c) Chemical structure of maitotoxin (MTX). 


\begin{tabular}{|c|c|c|c|c|c|c|}
\hline Order & Structure & Toxin & $\mathbf{R}_{1}$ & $\mathbf{R}_{2}$ & $\mathbf{R}_{3}$ & $\mathbf{R}_{4}$ \\
\hline \multirow{9}{*}{ (a) } & & \multicolumn{5}{|c|}{ Spirolides } \\
\hline & & SPX A & $\mathrm{H}$ & $\mathrm{CH}_{3}$ & $\mathrm{CH}_{3}$ & $\mathrm{H}$ \\
\hline & & SPX B & $\mathrm{H}$ & $\mathrm{CH}_{3}$ & $\mathrm{CH}_{3}$ & $\mathrm{H}$ \\
\hline & & SPX C & $\mathrm{CH}_{3}$ & $\mathrm{CH}_{3}$ & $\mathrm{CH}_{3}$ & $\mathrm{H}$ \\
\hline & & SPX D & $\mathrm{CH}_{3}$ & $\mathrm{CH}_{3}$ & $\mathrm{CH}_{3}$ & $\mathrm{H}$ \\
\hline & & 13-desmethyl SPX C & $\mathrm{CH}_{3}$ & $\mathrm{H}$ & $\mathrm{CH}_{3}$ & $\mathrm{H}$ \\
\hline & & 13, 19-desmethyl SPX C & $\mathrm{CH}_{3}$ & $\mathrm{H}$ & $\mathrm{H}$ & $\mathrm{H}$ \\
\hline & & 13-desmethyl SPX D & $\mathrm{CH}_{3}$ & $\mathrm{H}$ & $\mathrm{CH}_{3}$ & $\mathrm{H}$ \\
\hline & & 27-Hydroyx-13-didesmethyl SPX C & $\mathrm{CH}_{3}$ & $\mathrm{H}$ & $\mathrm{H}$ & $\mathrm{CH}_{3}$ \\
\hline \multirow{4}{*}{ (b) } & & \multicolumn{5}{|c|}{ Gymnodimines } \\
\hline & & GYM A & $\mathrm{H}$ & $\mathrm{H}$ & & \\
\hline & & GYM B & $\mathrm{H}$ & $\mathrm{OH}$ & & \\
\hline & & GYM C & $\mathrm{H}$ & $\mathrm{H}$ & & \\
\hline
\end{tabular}

Pteriatoxins

PtTX A

PtTX B

$$
\mathrm{OH}_{\mathrm{COOH}}^{\mathrm{S}} \mathrm{OH} \quad \mathrm{H} \quad \mathrm{H}
$$

(c)
-

Figure 3. Cont. 
Pinnatoxins

\begin{tabular}{|c|c|c|c|c|}
\hline PnTX A & $\xi \mathrm{COOH}$ & $\mathrm{OH}$ & $\mathrm{H}$ & $\mathrm{H}$ \\
\hline PnTX B and C & & $\mathrm{OH}$ & $\mathrm{H}$ & $\mathrm{H}$ \\
\hline PnTX D & & $\mathrm{H}$ & $\mathrm{OH}$ & $\mathrm{CH}_{3}$ \\
\hline PnTX E & & $\mathrm{H}$ & $\mathrm{OH}$ & $\mathrm{CH}_{3}$ \\
\hline PnTX F & & $\mathrm{H}$ & $\mathrm{OH}$ & $\mathrm{CH}_{3}$ \\
\hline PnTX G & & $\mathrm{OH}$ & $\mathrm{H}$ & $\mathrm{H}$ \\
\hline
\end{tabular}

Figure 3. Chemical structures of CI (SPXs (a), GYMs (b), PnTXs (c), and PtTXs (c),) and Silva et al. [79,83-86]. 


\subsubsection{Brevetoxins}

Brevetoxins (PbTxs) (Figure 4) are cyclic polyethers produced by dinoflagellates: Karenia spp. $[4,16,87]$ (Table 1 ). There are two known types of BTXs, named type A and type B (also called type $1(\mathrm{PbTx}-1)$ and type 2 (PbTx-2), respectively). The difference between two types of PbTxs consists in a few transfused rings that are ten for PbTx-1 and eleven for PbTx-2. The main analogs include PbTx-3, PbTx-6, PbTx-9, PbTx-B1, PbTx-B2, S-desoxy-PbTx-B2, PbTx-B3, PbTx-B4, and PbTx-B5 [44,88-94]. $\mathrm{PbT}$ xs are lipid-soluble cyclic polyether consisting of 10 to 11 transfused rings [95], stable and resistant to heat and steam autoclaving [96]. PbTxs cause neurotoxic shellfish poisoning (NSP) and actby binding with high affinity to receptor site 5 of the voltage-gated sodium channels $\left(\mathrm{Na}_{\mathrm{V}}\right)$ in cell membranes, and lactone is important for the toxin activity [97]. PbTxs are regulated in USA [98], New Zealand, and Australia [99,100] (Table 1).

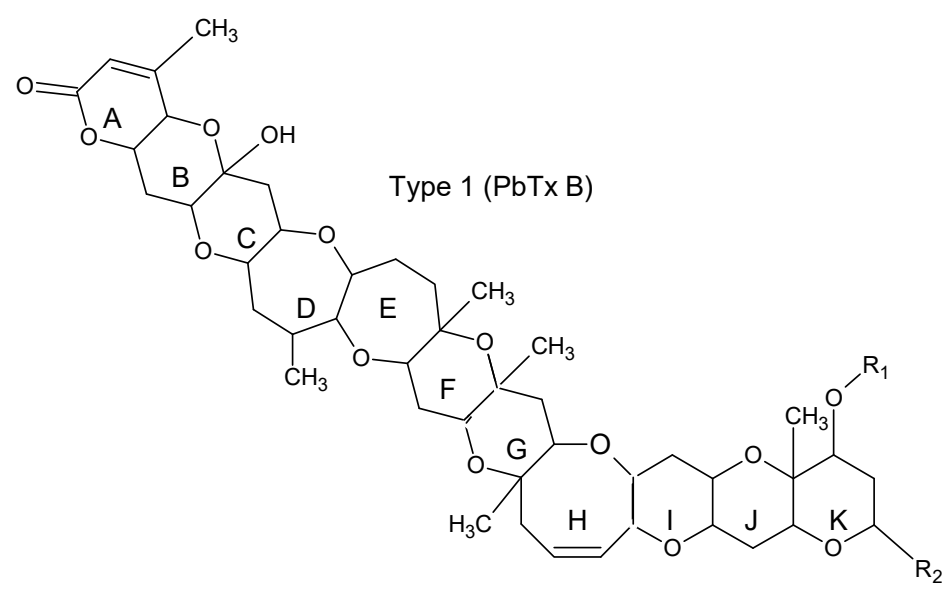

\begin{tabular}{ccc}
\hline Toxin & $\mathbf{R}_{\mathbf{1}}$ & $\mathbf{R}_{\mathbf{2}}$ \\
\hline PbTx-2 & $\mathrm{H}$ & $\mathrm{CH}_{2} \mathrm{C}\left[\mathrm{CH}_{2}\right] \mathrm{CHO}$ \\
PbTx-3 & $\mathrm{H}$ & $\left.\mathrm{CH}_{2} \mathrm{C}_{\mathrm{CH}}\right] \mathrm{CH}_{2} \mathrm{OH}$ \\
PbTx-5 & $\mathrm{COCH}_{3}$ & K-ring acetate $\mathrm{PbTx}-2$ \\
PbTx-6 & $\mathrm{H}$ & H-ring epoxide PbTx-2 \\
PbTx-8 & $\mathrm{H}$ & $\mathrm{CH}_{2} \mathrm{COCH}_{3} \mathrm{Cl}$ \\
PbTx-9 & $\mathrm{H}$ & $\mathrm{CH}_{2} \mathrm{CH}_{2}\left[\mathrm{CH}_{3}\right] \mathrm{CH}_{2} \mathrm{OH}$ \\
\hline
\end{tabular}

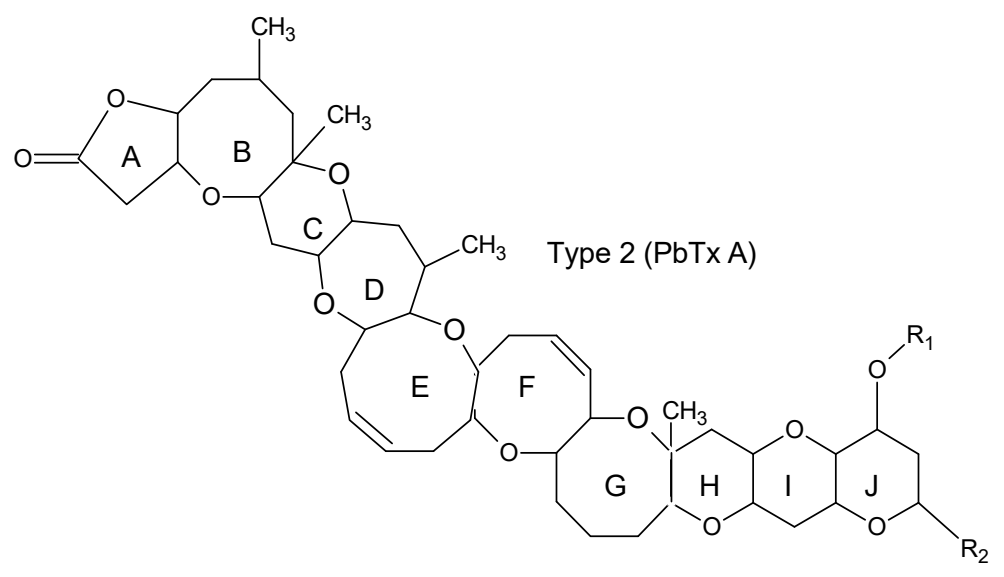

\begin{tabular}{cccc}
\hline Toxin & Type & $\mathbf{R}_{\mathbf{1}}$ & $\mathbf{R}_{\mathbf{2}}$ \\
\hline PbTx-1 & 2 & $\mathrm{H}$ & $\left.\mathrm{CH}_{2} \mathrm{C}_{\mathrm{CH}}\right] \mathrm{CHO}$ \\
PbTx-7 & 2 & $\mathrm{H}$ & $\mathrm{CH}_{2} \mathrm{C}\left[\mathrm{CH}_{3}\right] \mathrm{CH}_{2} \mathrm{OH}$ \\
PbTx-10 & 2 & $\mathrm{H}$ & $\mathrm{CH}_{2} \mathrm{CH}\left[\mathrm{CH}_{3}\right] \mathrm{CH}_{2} \mathrm{OH}$ \\
\hline
\end{tabular}

Figure 4. Chemical structures of the main group of PbTxs (PbTxs-A and PbTxs-B). The capital letter A in first ring indicates type A and type B (also called type 1and type 2, respectively [4]). These rings contain lactone group that is most important for the toxin activity. 


\subsubsection{Pectenotoxin Group}

Pectenotoxins (PTXs) (Figure 5) are lipophilic polyethers produced by several dinoflagellate species [101] (Table 1). They contain spiroketal, bicyclic ketal, cyclic hemiketals, and oxolanes in their structure. To date, more than 15 PTX analogs have been documented and many are derived through biotransformation of PTX2 in marine organism metabolism such as bivalve mollusks [102]. The most reported analogs include PTX1, epi-PTX1, PTX2, PTX2 seco acid (PTX2 SA), 7-epi-PTX2 seco acid (7-epi-PTX2 SA), PTX3, PTX4, PTX6, epi-PTX6, PTX7, PTX11 (34S-hydroxy-PTX2) [6,101,103-105]. PTXs are heat-stable and unstable under alkaline conditions [103]. PTX and analogs alter actin-based structures [103,106] causing cell death and apoptosis [107]. PTXs co-occur with the OA-group and contribute to DSP in humans [108].

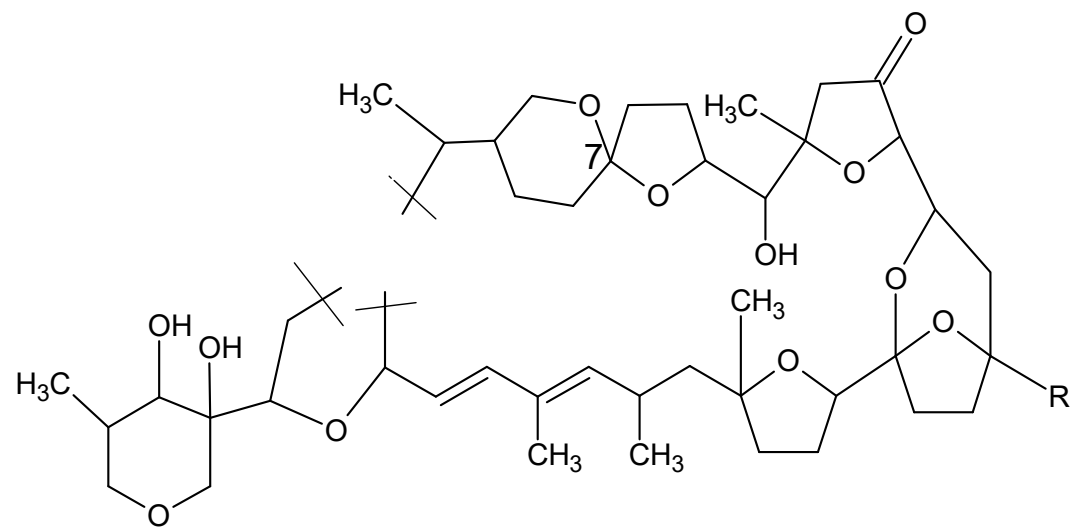

\begin{tabular}{|c|c|c|c|}
\hline Toxin & Structure & $\mathbf{R}$ & Configuration at $\mathrm{C7}$ \\
\hline PTX1 & & $\mathrm{CH}_{2} \mathrm{OH}$ & $\mathrm{R}$ \\
\hline PTX2 & & $\mathrm{CH}_{3}$ & $\mathrm{R}$ \\
\hline PTX3 & & $\mathrm{CHO}$ & $\mathrm{R}$ \\
\hline PTX4 & & $\mathrm{CH}_{2} \mathrm{OH}$ & $S$ \\
\hline PTX6 & & $\mathrm{COOH}$ & $\mathrm{R}$ \\
\hline PTX7 & & $\mathrm{COOH}$ & $S$ \\
\hline PTX11 & & $\mathrm{OH}$ & $\mathrm{R}$ \\
\hline PTX2 SA & & $\mathrm{CH}_{3}$ & $\mathrm{R}$ \\
\hline 7-ері-PTX2 SA & & $\mathrm{CH}_{3}$ & S \\
\hline
\end{tabular}

Figure 5. Chemical structures of main pectenotoxins.

\subsubsection{Yessotoxins}

Yessotoxins (YTXs) (Figure 6) are produced by dinoflagellates species: Protoceratium reticulatum [4,109], Lingulodinium polyhedral [4] and Gonyaulax polyhedra [4] (Table 1). They are a heat-stable polyether, with eleven transfused ether rings, an unsaturated side chain, and two sulfate esters [110]. To date, more than 90 YTX analogues have been isolated [102] and only YTX, 45-hydroxyYTX, carboxylic, 1a-homoYTX, 45,46,47-trinorYTX, ketoYTX, 40-epi-ketoYTX, 41a-homoYTX, 9Me-41a-homoYTX, 44,55-dihydroxyYTX, 45-hydroxy-1a-homoYTX, carboxy-1a-homoYTX [111] have been fully identified [111]. The mechanism of action of YTX and their analogs is not fully understood; however, they are involved in phosphodiesterase activation [112] and modulation of calcium migration at several levels [113], alteration of protein disposal [114], cell change 
shape [115], apoptosis and cell death [116]. To date, there are no reports of human illness associated with YTXs [111].

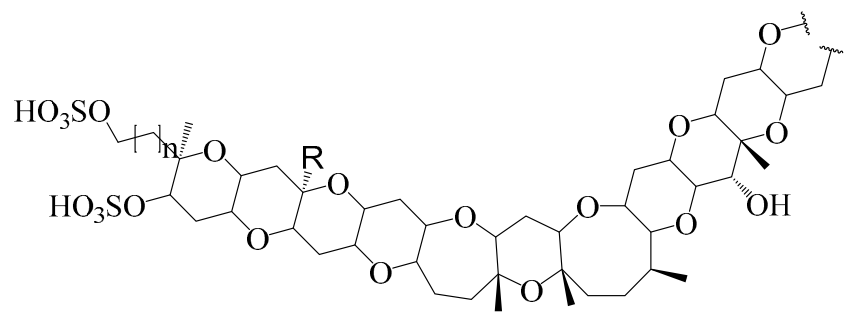

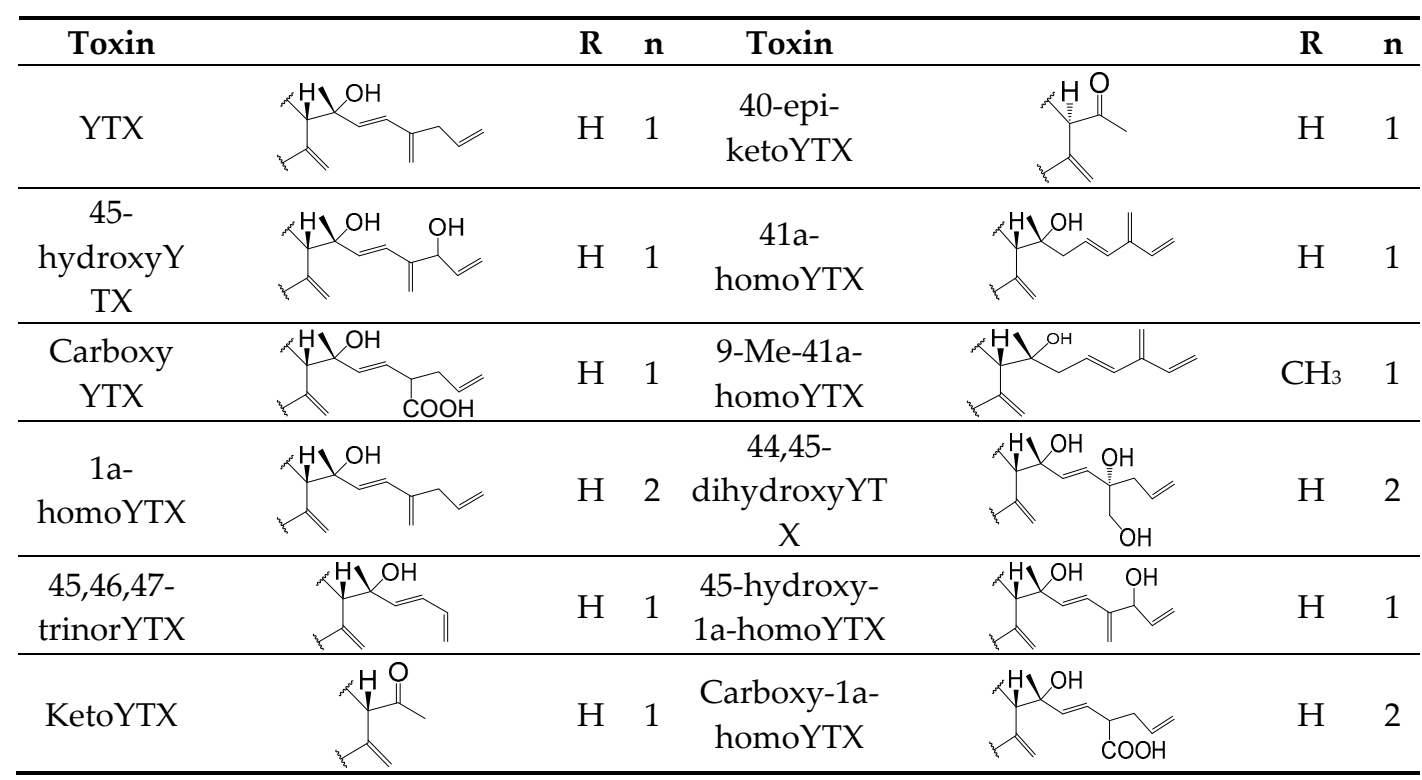

Figure 6. Chemical structures of YTXs n corresponds to the number of methyl groups in the molecule.

\subsubsection{Azaspiracids}

Azaspiracids (AZAs) (Figure 7) are toxins produced by dinoflagellates: Azadinium spinosum [117] and Protoperidinum crassipes [118] (Table 1). They are colorless, odorless and amorphous solids of toxins containing a heterocyclic amine, a unique tri-spiro-assembly and an aliphatic carboxylic acid in their structures [117,119-124]. Around 21 compounds of AZAs are well known and documented [117,119-124] of which AZA, AZA2, AZA3, AZA4, and AZA5 are the most prevalent ones based on occurrence and toxicity in humans. AZAs are responsible for the AZP syndrome (Table 1) and their mechanism of action is the inhibition of hERG voltage-gated potassium channels [125]. 


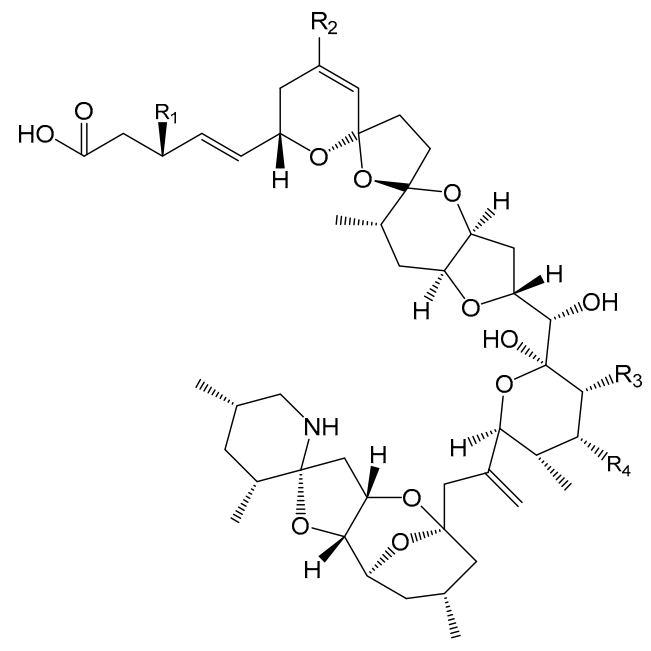

\begin{tabular}{ccccc}
\hline Toxin & $\mathbf{R}_{1}$ & $\mathbf{R}_{2}$ & $\mathbf{R}_{3}$ & $\mathbf{R}_{4}$ \\
\hline AZA & $\mathrm{H}$ & $\mathrm{H}$ & $\mathrm{CH}_{3}$ & $\mathrm{H}$ \\
AZA2 & $\mathrm{H}$ & $\mathrm{CH}_{3}$ & $\mathrm{CH}_{3}$ & $\mathrm{H}$ \\
AZA3 & $\mathrm{H}$ & $\mathrm{H}$ & $\mathrm{H}$ & $\mathrm{H}$ \\
AZA4 & $\mathrm{OH}$ & $\mathrm{H}$ & $\mathrm{H}$ & $\mathrm{H}$ \\
AZA5 & $\mathrm{H}$ & $\mathrm{H}$ & $\mathrm{H}$ & $\mathrm{OH}$ \\
\hline
\end{tabular}

Figure 7. Chemical structure of AZAs.

\subsection{Hydrophilic Toxins}

Hydrophilic Toxins are polar soluble compounds and they include domoic acid (DA) and analogs, Paralytic Shellfish Toxins (PSTs), tetrodotoxins (TTXs) and palytoxins (PITXs).

\subsubsection{Domoic Acid and Analogs}

Domoic acid (DA) (Figure 8) and analogs are polar cyclic amino acid toxins of diatom origin Pseudo-nitzschia spp. [126] and red algae: Chondria armata [127] (Table 1). They present three carboxylic acid groups and the most reported DA analogs include epi-domoic acid (epi-DA), domoic acid C5'-diastereomer and isodomoic acids A, B, C, D, E, F, G and H [iso-DA A-H] [128,129]. DA is the representative molecule of the DA-group that is responsible for amnesic shellfish poisoning (ASP) syndrome [130]. The characteristic symptomology of ASP is detailed in Table 1. 

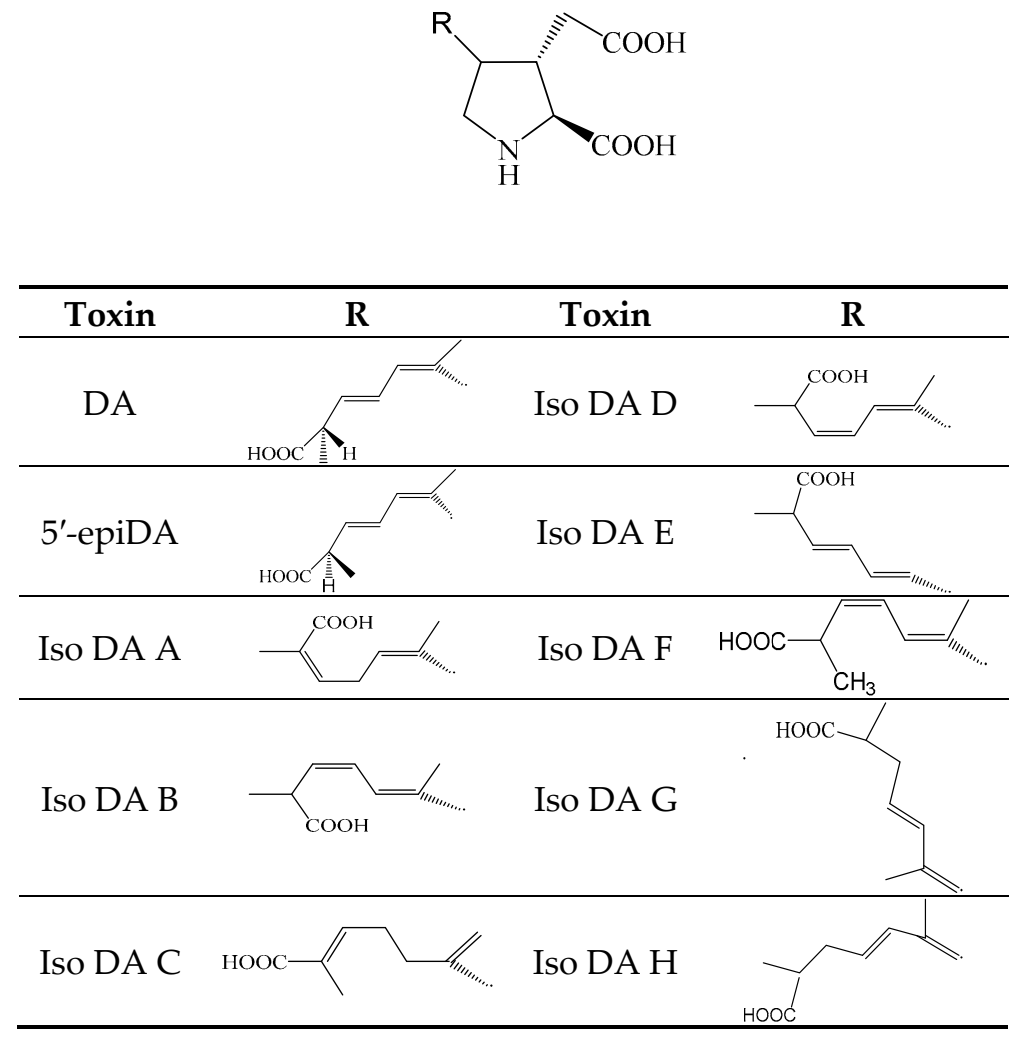

Figure 8. Chemical structure of DA and analogs.

\subsubsection{Paralytic Shellfish Toxins.}

Paralytic shellfish toxins (PSTs) (Figure 9) are water-soluble tetrahydropurine toxins produced mainly by dinoflagellates Alexandrium spp. [2,3,7], Gymnodinium catenatum [3], Pyrodinium bahamense [3] and by cyanobacteria Trichodesmium erythraeum [131] except M (Figure 9) toxins that are Mytilus spp. metabolism products [132]. This group is composed of several analogs and they are prone to various conversions depending on $\mathrm{pH}$ (Figure 9), being divided into several groups: carbamoyl (saxitoxin (STX), neosaxitoxin (NeoSTX) and gonyautoxins (GTX1-4)) decarbamoyl [dc-](dcSTX, dcNeoSTX, dcGTX1-4), Nsulfo-carbamoyl [GTX5-6, C1-4], hydroxylated saxitoxins [M1-4] [133-135] and benzoyl toxins (GC1-3) [135]. Their heat stability is $\mathrm{pH}$ dependent (except for Nsulfo-carbamoyl components) [136]. STX and analogs act by binding to Nav and consequently blocking ion conductance in nerves and muscles fibers leading to paralysis [137]. Symptoms resulting from PSTs poisoning are described in Table 1. 


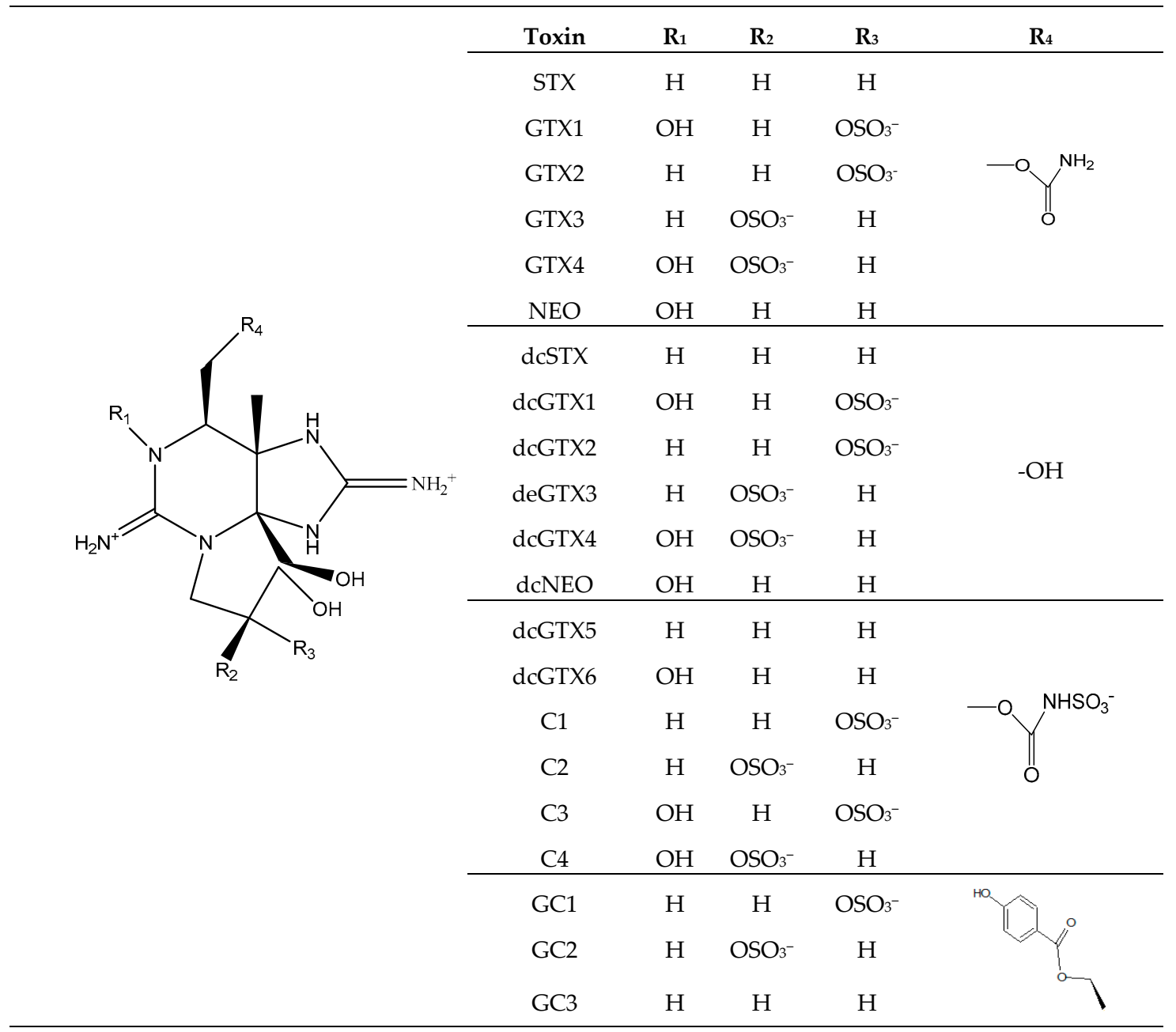

Figure 9. Chemical structures of STX group.

\subsubsection{Tetrodotoxins}

Tetrodotoxins (TTXs) (Figure 10) are toxins produced by bacteria in marine environments: Serratia marcescens, Vibrio spp. [83], Aeromonas sp. [138], Microbacterium arabinogalactanolyticum [139], Pseudomonas sp. [140], Shewanella putrefaciens [141], Alteromonas sp. [142], Pseudoalteromonas ssp. [143], and Nocardiopsis dassonvillei [144] (Table 1). They are colorless, crystalline-weak basic compounds with one positively charged guanidinium group and a pyrimidine ring $[145,146]$. TTXpoisoning has been recognized since ancient Egyptian times [42]. To date, TTX is considered an extremely potent emergent toxin in the Atlantic Ocean [83] and acts by binding to Nav on the surface of nerve cell membranes blocking the cellular communication and causing death by cardio-respiratory paralysis [147]. Several poisoning incidents have reported in Asia [Japan is the most affected country] [148], the Mediterranean Sea and the Indian Ocean [35]. TTX is usually concentrated in the ovaries, liver, intestines, and skin ofits principal vector [puffer fish] [42]. To date, the structures of 26 analogs of TTX have been fully elucidated but their relative toxicity and occurrence are not yet fully known $[145,146]$ except for 12compounds, namely, TTX, 11-oxoTTX, 11-deoxyTTX, 11-norTTX-6[R]-ol, 11-norTTX-6[S]-ol, 4-epiTTX, 4,9-anhydroTTX, 5,6,11-trideoxyTTX. [131], 4-CysTTX, 5-deoxyTTX, 5,11-dideoxyTTX, and 6,11-dideoxyTTX [149-152]. 


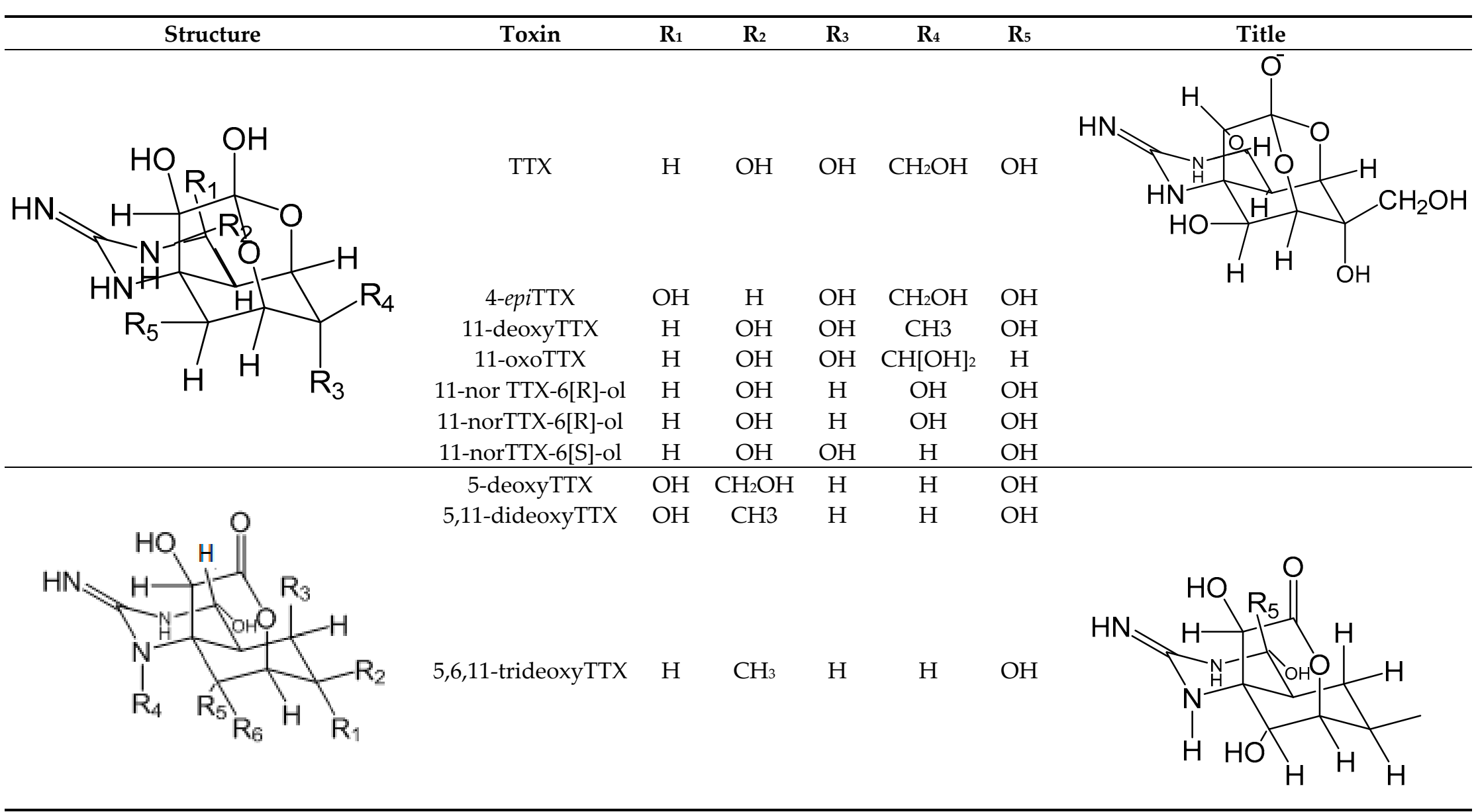

Figure 10. Chemical structure of TTX and their main analogues. 


\subsubsection{Palytoxin}

Palytoxin (PITX) and its derivatives (Figure 11) are toxins produced by marine zoanthids Palythoa spp., dinoflagellates: Ostreopsis ovata. [153-155] and possibly by cyanobacteria: Trichodesmium sp. [156] (Table 1). These polyhydroxylated toxins have both lipophilic and hydrophilic properties [157] with a partial unsaturated aliphatic backbone containing cyclic ethers, 64 chiral centers, 40-42 hydroxyl and 2 amide groups [157]. Among PITX analogs, known are: isobaric PITX, ostreocin-D, ovatoxin [a to f], mascarenotoxins, ostreotoxin-1 and 2, homopalytoxin, bishomopalytoxin, neopalytoxin, deopalytoxin and 42-hydroxypalytoxin and their molecular weights range from 2659 to 2680 DA [158-160]. PITX and analogs act on $\mathrm{Na}^{+}, \mathrm{K}^{+}$-ATPase pumps molecules in the cell membrane [161] and the loss of intracellular contents into the blood plasma and consequent injury causing rhabdomyolysis, among other signs, are the most reported as signs of PITX poisoning [161].

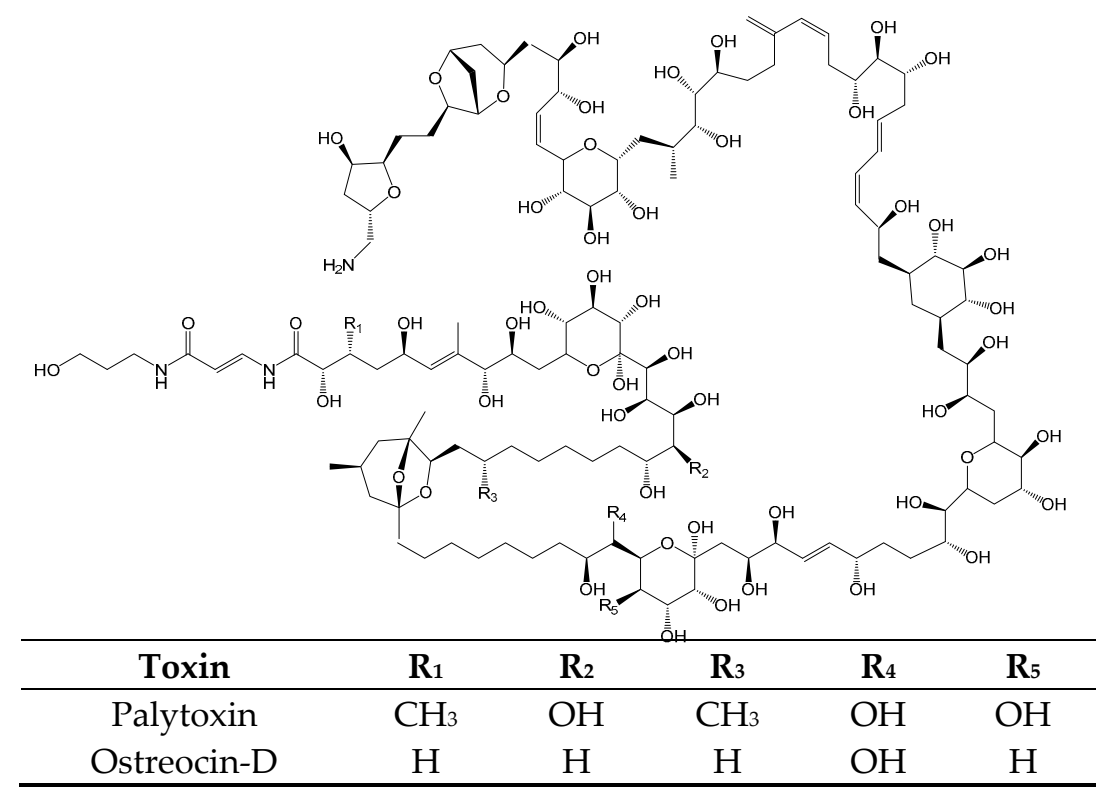

Figure 11. Chemical Structure of PITXs [PTX and Ostreocin-D].

\subsection{Marine Cyanotoxins}

Most marine toxins reported are produced mainly by microalgae (composed basically by dinoflagellates, diatoms, and marine bacteria), while cyanobacteria are reported as toxin producers in fresh, brackish waters and terrestrial habitats. Recently, cyanotoxins typical from freshwater have been identified in the marine environment [162]. Thus, this section will be focused on the description of the most reported marine cyanotoxins involved in seafood poisoning, their producers and mode of action (Table 1).

One of the most relevant groups of marine cyanotoxins is themicrocystin group (MCs) [163] (Figure 12). MCs are produced by cyanobacteria of genus Pseudoanabaena, Phormidium, Spirilia [164], Leptolyngbya, Oscillatoria, Geitlerinema [165], Trichodesmium [166] and Synechococcus [167] and their occurrence have been reported in many parts of the world, namely: the central Atlantic coast of Portugal [168], Canary Islands Archipelago [166], Brazilian coast [169], Amvrakikos Gulf (Greece) [167] and Indian Ocean [170]. To date, MCs is regulated in freshwater habitats but should be extended to the marine environments since there are reports of these hepatotoxins in marine environments [162]. 


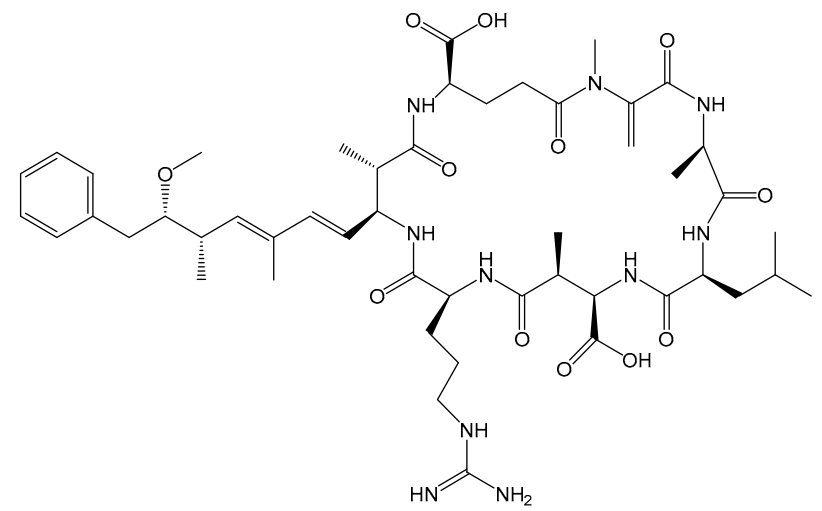

Figure 12. Chemical structure of MC.

Other reported marine cyanotoxins [in parenthesis is indicated their producers] (Figure 13) are aplysiatoxin (AT) [171] (Figure 13a), debromoaplysiatoxin (DAT) [171] (Figure 13) (algae Gracilaria coronopifolia [172] and cyanobacteria Lyngbya majuscule [171]), kalkitoxin (KTX) (cyanobacteria Lyngbyamajuscula [173]) (Figure 13b), lyngbyatoxins (LA, LB and LC) (cyanobacteria Lyngbya majuscule [174]) [Figure 13c], cylindrospermopsins (CYNs) (cyanobacteria Cylindrospermopsis raciborskii [175]) (Figure 13d), jamaicamides (JCDs) (Cyanobacteria Lyngbya majuscule [176]) (Figure 13e), anatoxins (ANTX) (cyanobacteria Hydrocoleum lyngbyaceum [177]) [178] (Figure 13f) andantillatoxins (ATX) (cyanobacteria Lyngbya majuscule [179]) (Figure 13g). The mechanism of action anddetection methods are presented in Table 1.

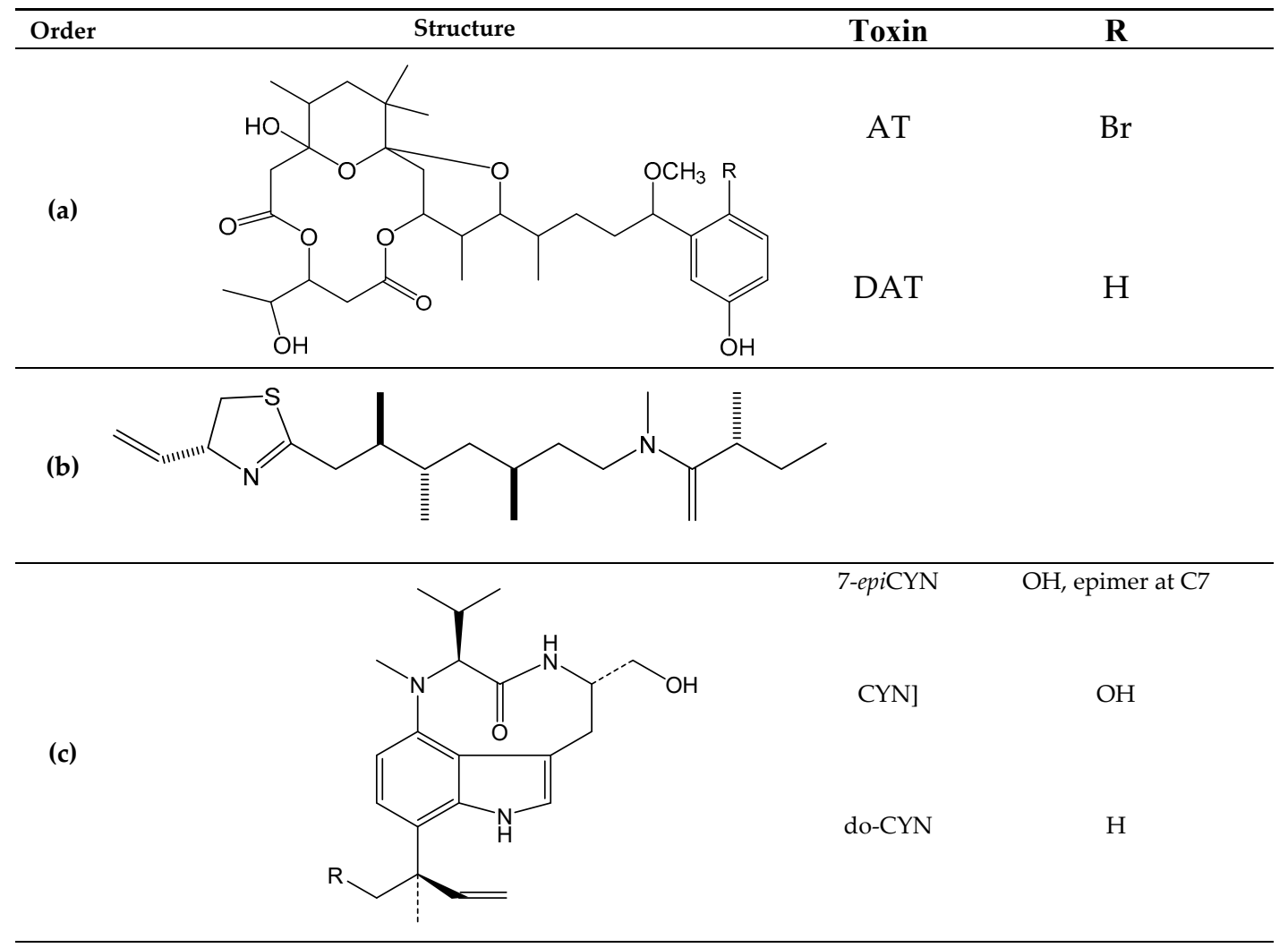

Figure 13. Cont. 
(d)<smiles>[R]C(c1cc(=O)[nH]c(O)n1)[C@H]1C[C@H]2C[C@H](O)[C@@H](C)[C@]3([2H])CN=C(N1)N23</smiles>

LA

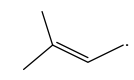

LB

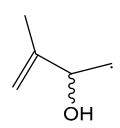

LC

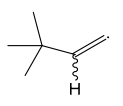

(e)<smiles>[R]CCCC(=CCl)CCC(C)C=CCCC(=O)NCCC(=CC(=O)N1C(=O)C=CC1C)OC</smiles>

JCD A $\mathrm{Br}=\stackrel{=}{=}$

JCD B

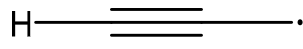

JCD C

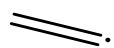

ANTX-

a

$\mathrm{CH}_{3}$

(f)

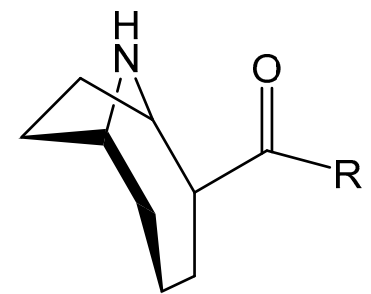

HANT

$X-a$

$\mathrm{CH}_{2} \mathrm{CH}_{3}$

(g)<smiles>[R][C@@](C)(C(=O)NCC(=O)O[C@](C)(/C(C)=C/C(C)=C/C(C)(C)C)C(C)(C)C(CC(=O)NC(C)(C)C(=C)C)=C(C)C)C(C)C</smiles>

ATX A

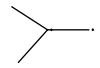

ATX B

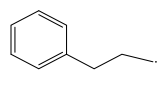

Figure 13. Chemical structures of Aplysiatoxin (AT) and Debromoaplysiatoxin (DAT) (a); kalkitoxins (KTX) (b); lyngbyatoxins A, B and C (LA, LB and LC) (c); cylindrospermopsins (CYN) (d); jamaicadimes (JCD) (e); anatoxin-a (ANTX) and homoanatoxin-a (HANTX) (f) and antillatoxins (ATX) (g).

Recent studies indicate Homoanatoxin-a (HANTX, a derivative of anatoxin-a) produced by the cyanobacteria Hydrocoleum sp. and Trichodesmium sp. which co-occur with G. toxicus, may be the causative toxin of CFP [43] (rather than CTXs). This evidence suggests further studies to clarify marine cyanotoxins responsible for CFP and their mechanism of action [178]. The reports of seafood poisoning involving marine cyanotoxins are very scarce and consequently, there is no specific symptomology that can be related to marine cyanotoxin human poisoning. 
Table 1. Marine toxins and their symptoms, producers, permitted limit, detection methods, limit of detection/limit of quantification [LOD/LOQ] and toxicity equivalency factors [TEF] according to the European Food Safety Authority [EFSA].

\begin{tabular}{|c|c|c|c|c|c|c|c|}
\hline \multirow{2}{*}{ Toxin (Syndrome) } & \multirow{2}{*}{ Symptoms } & \multicolumn{3}{|c|}{ Detection } & \multirow{2}{*}{ Permitted Limit } & \multirow{2}{*}{ Toxin (TEF) } & \multirow{2}{*}{ Producer } \\
\hline & & Methods & LOD, $\mu \mathrm{gKg}^{-1}$ & $\mathrm{LOQ} \mu \mathrm{gKg}^{-1}$ & & & \\
\hline \multirow{5}{*}{$\begin{array}{l}\text { OA and analogs } \\
\text { (DSP) }\end{array}$} & \multirow{5}{*}{$\begin{array}{c}\text { diarrhea, nausea, vomiting, } \\
\text { abdominal pain and tumor } \\
\text { formation in the digestive system } \\
{[50]}\end{array}$} & BA $[180,181]$ & 160 & & \multirow{5}{*}{$\begin{array}{l}0.16 \mathrm{mg} \mathrm{OA} \\
\text { equivalents } / \mathrm{Kg} \\
\text { shellfish meat in } \\
\text { EU region [182] }\end{array}$} & $\mathrm{OA}[\mathbf{1 . 0 ]}$ & \multirow{5}{*}{$\begin{array}{c}\text { Dinoflagellates: Prorocentrum spp. [8], } \\
\text { Dinophysis spp. }[2,6,9,10,15,53,54] \\
\text { and Phalacroma rotundatum }[55]\end{array}$} \\
\hline & & & & & & DTX1[1.0] & \\
\hline & & EIA $[183-180]$ & $10-26$ & $3-41$ & & DTX2 [0.6] & \\
\hline & & LC-MS [183], & $15-30$ & $1-50$ & & & \\
\hline & & & & & & DTX3 [1.0; 1; 0.6] & \\
\hline \multirow{4}{*}{$\begin{array}{l}\text { CTXs and analogs } \\
\text { (CFP) }\end{array}$} & \multirow{4}{*}{$\begin{array}{l}\text { vomiting, diarrhea, nausea, } \\
\text { tingling, itching, hypotension, } \\
\text { bradycardia. In extreme cases, } \\
\text { death through respiratory failure } \\
\text { in } 30 \text { min and } 48 \mathrm{~h} \text { after fish } \\
\text { consumption [50] }\end{array}$} & BA $[188,189]$ & $\begin{array}{c}0.16-0.560 \text { P-CTX } \\
{[190]}\end{array}$ & & \multirow{4}{*}{$\begin{array}{l}0.01 \mu \mathrm{g} \text { P-CTX-1 } \\
\text { equivalents } / \mathrm{kg} \text { of } \\
\text { fish in USA [191] }\end{array}$} & P-CTX-1[1.0] & \multirow{4}{*}{$\begin{array}{l}\text { Dinoflagellates: Gambierdiscus toxicus, } \\
\text { Ostreopsis siamensis and Prorocentrum } \\
\text { lima [59] }\end{array}$} \\
\hline & & CTA [192-194] & $\sim 10^{6}-0.039$ C-СТХ & & & P-CTX-2[0.3] & \\
\hline & & $\begin{array}{c}\text { EIA } \\
{[72,189,195-199]} \\
\end{array}$ & -0.032 Р-СТX & & & 2,3-dihydroxy P-CTX-3C[1.0] & \\
\hline & & $\begin{array}{c}\text { LC-MS/MS } \\
\text { [67,70,71,74,200], } \\
\text {-UVD }[62,201,202]\end{array}$ & & & & С-СТХ-1[0.1] & \\
\hline \multirow{3}{*}{ CIs } & \multirow{3}{*}{$\begin{array}{l}\text { non-specific symptoms such as } \\
\text { gastric distress and tachycardia in } \\
\text { humans [82] }\end{array}$} & BA & 5.6-77 PnTXE & & \multirow{3}{*}{ Not regulated } & \multirow{3}{*}{ 13-desmethyl SPX C[1.0] } & \multirow{3}{*}{$\begin{array}{l}\text { Dinoflagellates: SPXs: Alexandrium } \\
\text { spp. [1,76], GYMs: Gymnodium spp. } \\
\text { [77], PnTXs: Vulcanodinium rugosum } \\
\text { [78] and PtTXs: biotransformation } \\
\text { from PnTXs via metabolic and } \\
\text { hydrolytic transformation in shellfish } \\
\text { [1,5,77-79] }\end{array}$} \\
\hline & & FPA [203] & 80-85 13-SPXC & & & & \\
\hline & & $\begin{array}{c}\text { LC-MS/MS } \\
{[79,204],- \text { UVD }} \\
{[205]}\end{array}$ & $\begin{array}{c}0.8-20 \\
\text { 13-SPXC/GYMA }\end{array}$ & & & & \\
\hline \multirow{5}{*}{$\begin{array}{l}\text { PbTxs and analogs } \\
\text { (NSP) }\end{array}$} & \multirow{5}{*}{$\begin{array}{l}\text { nausea, vomiting, diarrhea, } \\
\text { paresthesia, cramps, } \\
\text { bronchoconstriction, paralysis, } \\
\text { seizures in } 30 \text { min to } 3 \mathrm{~h} \mathrm{[87]}\end{array}$} & BA [206] & & & \multirow{5}{*}{$\begin{array}{c}800 \mu \mathrm{\mu g} \text { BTX-2 } \\
\text { equivalents } / \mathrm{kg} \\
\text { shellfish in USA } \\
\text { [98], New Zealand, } \\
\text { and Australia } \\
\text { [99,100] }\end{array}$} & \multirow{5}{*}{$\begin{array}{l}\text { BTX-2, BTX-3, BTX2-B2 and } \\
\text { S-deoxy-BTX-B2 [same TEF] }\end{array}$} & \multirow{5}{*}{ Dinoflagellate: Karenia spp. $[4,16,87]$} \\
\hline & & CTA [192] & 250 BTX-1 & & & & \\
\hline & & RB [108] & 30BTX-3 & & & & \\
\hline & & EIA $[207,208]$ & $1 \mathrm{BTX}$ s and & 25 BTXs & & & \\
\hline & & LC-MS/MS [209] & $0.2-2$ BTXs & & & & \\
\hline \multirow{3}{*}{ PTX and analogs } & \multirow{3}{*}{ No specific symptoms } & MBA & - & & \multirow{3}{*}{$\begin{array}{l}160 \mu \mathrm{g} \mathrm{OA} \\
\text { equivalents. } / \mathrm{kg} \\
\text { shellfish meat in } \\
\text { EU region [210] }\end{array}$} & PTX $[1,2,3,4,6$ and 11$][\mathbf{1 . 0}]$ & \multirow{3}{*}{ Dinoflagellate: Dinophysis acuta [101] } \\
\hline & & EIA [207] & - & & & & \\
\hline & & $\begin{array}{c}\text { LC - MS /MS } \\
{[211,212]}\end{array}$ & 1 & & & 7-epiPTX2 SA $[<<10]$ & \\
\hline
\end{tabular}


Table 1. Cont

\begin{tabular}{|c|c|c|c|c|c|c|c|}
\hline \multirow{2}{*}{ Toxin (Syndrome) } & \multirow{2}{*}{ Symptoms } & \multicolumn{3}{|c|}{ Detection } & \multirow{2}{*}{ Permitted Limit } & \multirow{2}{*}{ Toxin (TEF) } & \multirow{2}{*}{ Producer } \\
\hline & & Methods & $\mathrm{LOD} \mu \mathrm{gKg}^{-1}$ & LOQ, $\mu \mathrm{gKg}^{-1}$ & & & \\
\hline \multirow{4}{*}{ YTX and analogs } & \multirow{4}{*}{ No specific symptoms } & BA & & & \multirow{4}{*}{$\begin{array}{l}3.75 \mathrm{mg} \text { YTX } \\
\text { equivalents } / \mathrm{Kg} \\
\text { shellfish meat in } \\
\text { EU region [124] }\end{array}$} & YTX[1.0] & \multirow{4}{*}{$\begin{array}{c}\text { Dinoflagellate: Protoceratium } \\
\text { reticuatum }[4,109], \text { Lingulodinium } \\
\text { polyedrum }[4] \text { and Gonyaulax } \\
\text { polyhedral }[4]\end{array}$} \\
\hline & & EIA [213] & & & & 1a-homoYTX[1.0] & \\
\hline & & \multirow{2}{*}{ LC-MS/MS [111] } & \multirow{2}{*}{0.017} & & & & \\
\hline & & & & & & 45-hydroxy-1a-homoYTX[0.5] & \\
\hline \multirow{6}{*}{$\begin{array}{l}\text { AZA and analogs } \\
\text { (AZP) }\end{array}$} & \multirow{6}{*}{$\begin{array}{c}\text { nausea, vomiting, diarrhea and } \\
\text { decreased reaction to stomach } \\
\text { cramps, deep pain, dizziness, } \\
\text { hallucinations, confusion, } \\
\text { short-term memory loss, seizure } \\
\text { [214] }\end{array}$} & \multirow{2}{*}{ BA [181] } & \multirow{6}{*}{0.05} & & \multirow{6}{*}{$\begin{array}{c}0.16 \mathrm{mg} \\
\text { AZA1equivalents } \\
/ \mathrm{Kg} \text { shellfish in EU } \\
\text { region [210] }\end{array}$} & AZA1[1.0] & \multirow{6}{*}{$\begin{array}{c}\text { Dinoflagellates: Azadinium spinosum } \\
\text { [117] and } \\
\text { Protoperidinum crassipes [118] }\end{array}$} \\
\hline & & & & & & $47 \wedge 2[18]$ & \\
\hline & & \multirow{4}{*}{ LC-MS/MS } & & & & AZA2[1.0] & \\
\hline & & & & & & AZA3[1.4] & \\
\hline & & & & & & AZA4[0.4] & \\
\hline & & & & & & AZA5[0.2] & \\
\hline \multirow{15}{*}{$\begin{array}{l}\text { STX and analogs } \\
\text { (PSP) }\end{array}$} & \multirow{15}{*}{$\begin{array}{c}\text { Numbness in the face and neck; } \\
\text { headache, } \\
\text { dizziness, nausea, vomiting, } \\
\text { diarrhea, muscular paralysis; } \\
\text { pronounced respiratory difficulty; } \\
\text { death through respiratory } \\
\text { paralysis [215] }\end{array}$} & \multirow{2}{*}{ BA $[216,217]$} & & & \multirow{15}{*}{$\begin{array}{l}0.8 \mathrm{mg} \text { STX } \\
\text { equivalent } / \mathrm{Kg} \\
\text { shellfish in EU } \\
\text { region [210] }\end{array}$} & STX[1.0] & \multirow{15}{*}{$\begin{array}{c}\text { Dinoflagellates: Alexandrium spp. } \\
\text { [2,3,7], Gymnodinium catenatum [3], } \\
\text { Pyrodinium bahamense [3] and } \\
\text { cyanobacteria Trichodesmium } \\
\text { erythraeum }[131]\end{array}$} \\
\hline & & & & & & NSTX[1.0] & \\
\hline & & \multirow{3}{*}{ SBA [218] } & & & & GTX1[1.0] & \\
\hline & & & & & & GTX2[0.4] & \\
\hline & & & & & & GTX3[0.6] & \\
\hline & & \multirow{2}{*}{ CTA [192,219] } & & & & GTX4[0.7] & \\
\hline & & & & & & GTX5[0.1] & \\
\hline & & \multirow{2}{*}{$\begin{array}{c}\text { Antibodies Assay } \\
{[220-224]}\end{array}$} & & & & GTX[0.1] & \\
\hline & & & & & & $\mathrm{C} 2[0.1]$ & \\
\hline & & \multirow{2}{*}{$\begin{array}{l}\text { Eletrophoresis } \\
\text { [225] }\end{array}$} & & & & $\mathrm{C} 4[\mathbf{0 . 1}]$ & \\
\hline & & & & & & de-STX[1.0] & \\
\hline & & \multirow{4}{*}{$\begin{array}{l}\text { LC-MS/MS } \\
\text { [226-229] }\end{array}$} & \multirow{4}{*}{ 23-42 STX } & & & de-GTX3[0.2] & \\
\hline & & & & & & de-NSTX2[0.2] & \\
\hline & & & & & & de-GTX3[0.4] & \\
\hline & & & & & & 11-hydroxy-STX[0.3] & \\
\hline
\end{tabular}


Table 1. Cont

\begin{tabular}{|c|c|c|c|c|c|c|c|}
\hline \multirow{2}{*}{ Toxin (Syndrome) } & \multirow{2}{*}{ Symptoms } & \multicolumn{3}{|c|}{ Detection } & \multirow{2}{*}{ Permitted Limit } & \multirow{2}{*}{ Toxin (TEF) } & \multirow{2}{*}{ Producer } \\
\hline & & Methods & LOD, $\mu \mathrm{gKg}^{-1}$ & $\mathrm{LOQ}_{,} \mu \mathrm{gKg}^{-1}$ & & & \\
\hline \multirow{7}{*}{$\begin{array}{l}\text { DA and analogs } \\
\text { (ASP) }\end{array}$} & \multirow{7}{*}{$\begin{array}{l}\text { nausea, vomiting, diarrhea or } \\
\text { abdominal cramps] within } 24 \mathrm{~h} \text { of } \\
\text { consuming DA contaminated } \\
\text { shellfish and/or neurological } \\
\text { symptoms or signs [confusion, } \\
\text { loss of memory or other serious } \\
\text { signs such as seizure or coma] } \\
\text { occurring within } 48 \mathrm{~h}\end{array}$} & BA [230] & 40 & & \multirow{7}{*}{$\begin{array}{l}20 \mathrm{mg} \mathrm{DA} \\
\text { equivalents } / \mathrm{Kg} \\
\text { shellfish in EU } \\
\text { region [210] }\end{array}$} & & \multirow{7}{*}{$\begin{array}{l}\text { Diatoms: Pseudo-nitzschia spp. [126] } \\
\text { and red algae: Chondria armata [127]. }\end{array}$} \\
\hline & & $\begin{array}{l}\text { (a) ASP- EIA } \\
{[184,231]} \\
\end{array}$ & 0.003 & 0.01 & & & \\
\hline & & SPR [232] & 20 & & & & \\
\hline & & RB [233-235] & 20 & & & & \\
\hline & & $\begin{array}{c}\text { Capillary } \\
\text { electrophoresis } \\
{[236-238]}\end{array}$ & $0.15-1$ & & & & \\
\hline & & $\begin{array}{c}\text { LC-MS/MS } \\
\text { [211,239,240], } \\
\text { UVD }[241,242]\end{array}$ & 0.015 & & & & \\
\hline & & TLC [243] & 10 & & & & \\
\hline \multirow{6}{*}{ TTX and analogs } & \multirow{6}{*}{$\begin{array}{l}\text { Vomiting, strong headache, } \\
\text { muscle weakness, respiratory } \\
\text { failure, hypotension and even } \\
\text { death in hours [244] }\end{array}$} & BA [144,245-247] & $1.1[247]$ & & \multirow{6}{*}{$\begin{array}{c}2 \mathrm{mg} \text { TTX } \\
\text { equivalents } / \mathrm{Kg} \\
\text { shellfish in Japan } \\
\text { [248] }\end{array}$} & \multirow{2}{*}{$\begin{array}{c}\mathrm{S} / \mathrm{R} \\
\text { 11-norTTX-[6]-ol[0.19/0.17] }\end{array}$} & \multirow{6}{*}{$\begin{array}{c}\text { Bacteria: Serratia marcescens, Vibrio } \\
\text { spp. [83], V. Aeromonas sp. [138], } \\
\text { Microbacterium, } \\
\text { arabinogalactanolyticum [139], } \\
\text { Pseudomonas sp. [140], Shewanella } \\
\text { putrefaciens [141], Alteromonas sp. } \\
\text { [142], Pseudoalteromonas sp. [143], } \\
\text { and Nocardiopsis dassonvillei [144] }\end{array}$} \\
\hline & & RB [249] & $2-4.10^{-3}$ TTX & & & & \\
\hline & & $\begin{array}{c}\text { EIA } \\
{[245-247,250-256]}\end{array}$ & $\begin{array}{c}0.002 / \mathrm{mL}[255], 0 . \\
0001 / \mathrm{mL}[253]\end{array}$ & & & 4-epiТTХ[0.16] & \\
\hline & & $\operatorname{TLC}[139,257]$ & $2[257]$ & & & 4,9-anhydroTTX[0.02] & \\
\hline & & $\begin{array}{c}\text { GC-MS } \\
{[28,258,259]}\end{array}$ & 500 & $1000[258]$ & & $x, y-$ aाш & \\
\hline & & $\begin{array}{c}\text { LC-MS/MS } \\
\text { [260-264] - FLD } \\
{[265]} \\
\end{array}$ & $\begin{array}{l}0.00009 ?-24.5 \\
{[260-264]}\end{array}$ & $40[265]-100[265]$ & & 5,6,11-deoxyTTX[0.01] & \\
\hline \multirow{5}{*}{ PITX } & \multirow{5}{*}{$\begin{array}{l}\text { Vasoconstriction, hemorrhage, } \\
\text { myalgia, ataxia, muscle weakness, } \\
\text { ventricular fibrillation, ischemia } \\
\text { and death [266,267] and } \\
\text { rhabdomyolysis [268] }\end{array}$} & BA & & & \multirow{5}{*}{$\begin{array}{l}\text { Not regulated } \\
\text { toxin but proposed } \\
\text { value is } 0.25 \mathrm{mg} \\
\text { PITX } \\
\text { equivalent } / \mathrm{Kg} \\
\text { shellfish in EU } \\
\text { region [269] }\end{array}$} & \multirow{5}{*}{ streocin-D[0.4-1.0] } & \multirow{5}{*}{$\begin{array}{c}\text { Zoanthids: Palythoa spp. } \\
\text { anddinoflagellates: Ostreopsis ovata. } \\
\text { [153-155] and possibly cyanobacteria: } \\
\text { Trichodesmium sp. [156] }\end{array}$} \\
\hline & & $\begin{array}{l}\text { Hemolysis assay } \\
{[270]}\end{array}$ & 1.6 & & & & \\
\hline & & CTA [107] & 50 & & & & \\
\hline & & EIA [254] & $1 / \mathrm{mL}$ & & & & \\
\hline & & $\begin{array}{c}\text { LC-MS/MS } \\
\text { [204,271]-FLD } \\
\text { and-UVD [272] }\end{array}$ & $\begin{array}{l}2,5 \cdot 10^{-5}-0 \\
50.10^{-5}\end{array}$ & & & & \\
\hline
\end{tabular}


Table 1. Cont.

\begin{tabular}{|c|c|c|c|c|c|c|c|}
\hline \multirow{2}{*}{ Toxin (Syndrome) } & \multirow{2}{*}{ Symptoms } & \multicolumn{3}{|c|}{ Detection } & \multirow{2}{*}{ Permitted Limit } & \multirow{2}{*}{ Toxin (TEF) } & \multirow{2}{*}{ Producer } \\
\hline & & Methods & LOD, $\mu \mathrm{gKg}^{-1}$ & LOQ, $\mu \mathrm{gKg}^{-1}$ & & & \\
\hline MC & $\begin{array}{c}\text { liver hemorrhage within a few } \\
\text { hours of an acute dose and death } \\
\text { [273] }\end{array}$ & $\begin{array}{c}\text { LC-MS } \\
{[167,274-276] \text { and }} \\
\text { EIA [277] }\end{array}$ & & & $\begin{array}{c}\text { Tolerable daily } \\
\text { intake: } 0.04 \mu \mathrm{g} / \mathrm{kg} \\
\text { of MC body } \\
\text { weight/day [278] }\end{array}$ & & $\begin{array}{c}\text { Cyanobacteriaof genus: Pseudoanabaena, } \\
\text { Phormidium, Spirilia [164], Leptolyngbya, } \\
\text { Oscillatoria, Geitlerinema [165], } \\
\text { Trichodesmium [166] and Synechococcus } \\
\text { [167] }\end{array}$ \\
\hline ANTX and HANTX & $\begin{array}{c}\text { Hypersalivation, diarrhea, } \\
\text { shaking and nasal mucus } \\
\text { discharge [279], respiratory arrest } \\
\text { and death [280] }\end{array}$ & $\begin{array}{c}\mathrm{RB} \text { and GC/MS } \\
{[281,282]}\end{array}$ & & & & & $\begin{array}{c}\text { Cyanobacteria: Hydrocoleum lyngbyaceum } \\
{[177]}\end{array}$ \\
\hline
\end{tabular}

AT and DAT Contact dermal: dermatitis initiating with erythema and few hours after exposure, gave way to blister formation and deep way to blister formation and deep desquamation, lasting up to
several days $[283,284]$ and consumption of contaminated seafood: burningsensation in the mouth and throat vomiting and diarrhea [285]
Cyanobacteria Lyngbya majuscule [174]

\begin{tabular}{|c|c|c|c|}
\hline ATX and analogs & No specific symptoms & LC [287] & Cyanobacteria: Lyngbya majuscula [179] \\
\hline JCD and analogs & No specific symptoms & LC, TLC and [288] & Cyanobacteria: Lyngbya majuscula [176] \\
\hline KTX and analogs & No specific symptoms & LC [173] & Cyanobacteria: Lyngbya majuscula [173] \\
\hline \multirow[t]{2}{*}{ CYN and analogs } & \multirow[t]{2}{*}{ Gastroenteritis [289] } & $\begin{array}{cc}\text { LC-MS/MS } & \\
\text { [290],-PDAD [291] } & \text { [292]-200 [293] }\end{array}$ & \multirow{2}{*}{$\begin{array}{c}\text { Cyanobacteria: Cylindrospermopsis } \\
\text { raciborskii }[175]\end{array}$} \\
\hline & & EIA [294] & \\
\hline
\end{tabular}

Toxins: DA—domoic acid, DTX, CTX -ciuatoxin, AZA—azaspiracid, CI—cyclic imines, PTX—pectenotoxin, YTX—yessotoxin, STX—saxitoxin, OA—okadaic acid, BTX—revetoxin,

PITX - palytoxin, TTX -tetrodotoxin, MC—-microcystin, ANTX-anatoxin, HANTX-homoanatoxin, LA, LB and LC—lyngbyatoxins A, B and C respectively. ATX-antillatoxin,

KTX-kalkitoxin, CYN—cylindrospermopsins AT—aplysiatoxin, DAT—debromoaplysiatoxin, JCD-jamaicamides, Syndrome: PSP-Paralyc Poisoning, DSP-Diarrheic Shellfish Poisoning, ASP-Amnesic Shellfish Poisoning, AZP-Azaspiracid Shellfish Poisoning, CFP-CiguateraShellfish Poisoning, NSP-Neurologic Shellfish Poisoning, Detection methods: CTA-Cytotoxicity assay, EIA—Enzyme-ImmunoAssay, SPR—Surface Plasmon Resonance, RB-Receptor-based, GC—Gas Chromatography, BA-Bioassay; UVD-Ultra Violet Detection; LC-Liquid Chromatography and MS—Mass Spectroscopy, FPA—Fluorescence Polarization Assay, TLC—Thin Layer Chromatography, SBA—Saxitoxin Binding Assay, PDAD—photo diode array detection. 


\section{Incidence of Harmful Algal Blooms MarineToxins and Consequent Poisoning Incidents along African Indian and the Red Sea Coasts}

The main geographical focus of this review is the African Indian and the Red Sea coasts, including surrounding islands (Figure 14). The marine environment of this area is understudied due to a lack of monitoring infrastructure. There is a high rate of poverty in local communities, and the local population is vulnerable to natural disasters [including HABs, tropical storms]. The exponential increase in population accompanied by industrialization and climate change contributes to eutrophication in coastal areas $[295,296]$. This study area is characterized as subtropical to tropical climate with a water temperature above $20{ }^{\circ} \mathrm{C}$ [297]. Eutrophication and the transportation of cysts [through maritime traffic] are considered the main factors contributing to large phytoplankton blooms, including those comprised of HAB species and/or pathogenic bacteria $[295,296]$. Countries with monitoring programs of marine environments related to control of seafood poisoning are listed in Table 2. A few of these programs have noted the presence of MTs (Figure 14) and HAB species [dinoflagellates, cyanobacteria, diatoms], some of which [HAB species] were detected/confirmed by microscopic techniques and some confirmed by partial $16 \mathrm{~S}$ rRNA genes analysis [12,13,298-323].

Table 2. MT monitoring scenario of the African countries of the Indian Ocean and the Red Sea.

\begin{tabular}{|c|c|c|c|c|c|}
\hline Country & Monitored MT & $\begin{array}{c}\text { Permitted Limit, } \\
\mathrm{mgKg}^{-1} \text { Shellfish }\end{array}$ & Detection & $\begin{array}{l}\text { Laboratories for } \\
\text { Toxin Analysis }\end{array}$ & Reference \\
\hline \multirow{5}{*}{ South Africa } & PST & $0.8 \mathrm{STX}$ & & \multirow{5}{*}{$\begin{array}{c}\text { Research centers and } \\
\text { Universities }\end{array}$} & \multirow{5}{*}{ [324] } \\
\hline & OA, DTX1-2, PTX1-2 & $0.16 \mathrm{mg} \mathrm{OA}$ & LC-MS/MS & & \\
\hline & $\begin{array}{c}\text { YTX, } 45 \text { OH YTX, } \\
\text { homo YTX, and } 45 \\
\text { OH homo YTX }\end{array}$ & $8 \mathrm{mg}$ YTX & LC-MS/MS & & \\
\hline & AST & $20 \mathrm{mg}$ DA & & & \\
\hline & AZA1-3 & $0.16 \mathrm{mg} \mathrm{OA}$ & LC-MS/MS & & \\
\hline Mozambique & N.D. & N.D. & N.D. & N.D. & N.D. \\
\hline Tanzania & CTX, TTX, AST & N.D. & $\begin{array}{l}\text { Symptomology } \\
\text { and vectors }\end{array}$ & N.D. & [325] \\
\hline Kenya & MT producers [HAB] & N.D. & N.D. & $\begin{array}{c}\text { Mombasa Research } \\
\text { Center }\end{array}$ & [326] \\
\hline Madagascar & N.D. & N.D. & $\begin{array}{c}\text { Educational } \\
\text { programmes }\end{array}$ & $\begin{array}{c}\text { Researches centers } \\
\text { and Universities }\end{array}$ & [327] \\
\hline French Islands & N.D. & N.D. & N.D. & Researches centers & {$[35,328]$} \\
\hline Mauritius & N.D. & N.D. & N.D. & & [324] \\
\hline Comoros & N.D. & N.D. & N.D. & N.D. & \\
\hline $\begin{array}{l}\text { Somalia and } \\
\text { Seychelles }\end{array}$ & N.D. & N.D. & N.D. & N.D. & \\
\hline Eygpt & N.D. & N.D. & N.D. & $\begin{array}{c}\text { Poison Control } \\
\text { Center, Ain Shams } \\
\text { University }\end{array}$ & {$[329,330]$} \\
\hline Djibouti & N.D. & N.D. & N.D. & N.D. & \\
\hline Eritrea & N.D. & N.D. & N.D. & N.D. & \\
\hline Sudan & N.D. & N.D. & N.D. & N.D. & \\
\hline
\end{tabular}




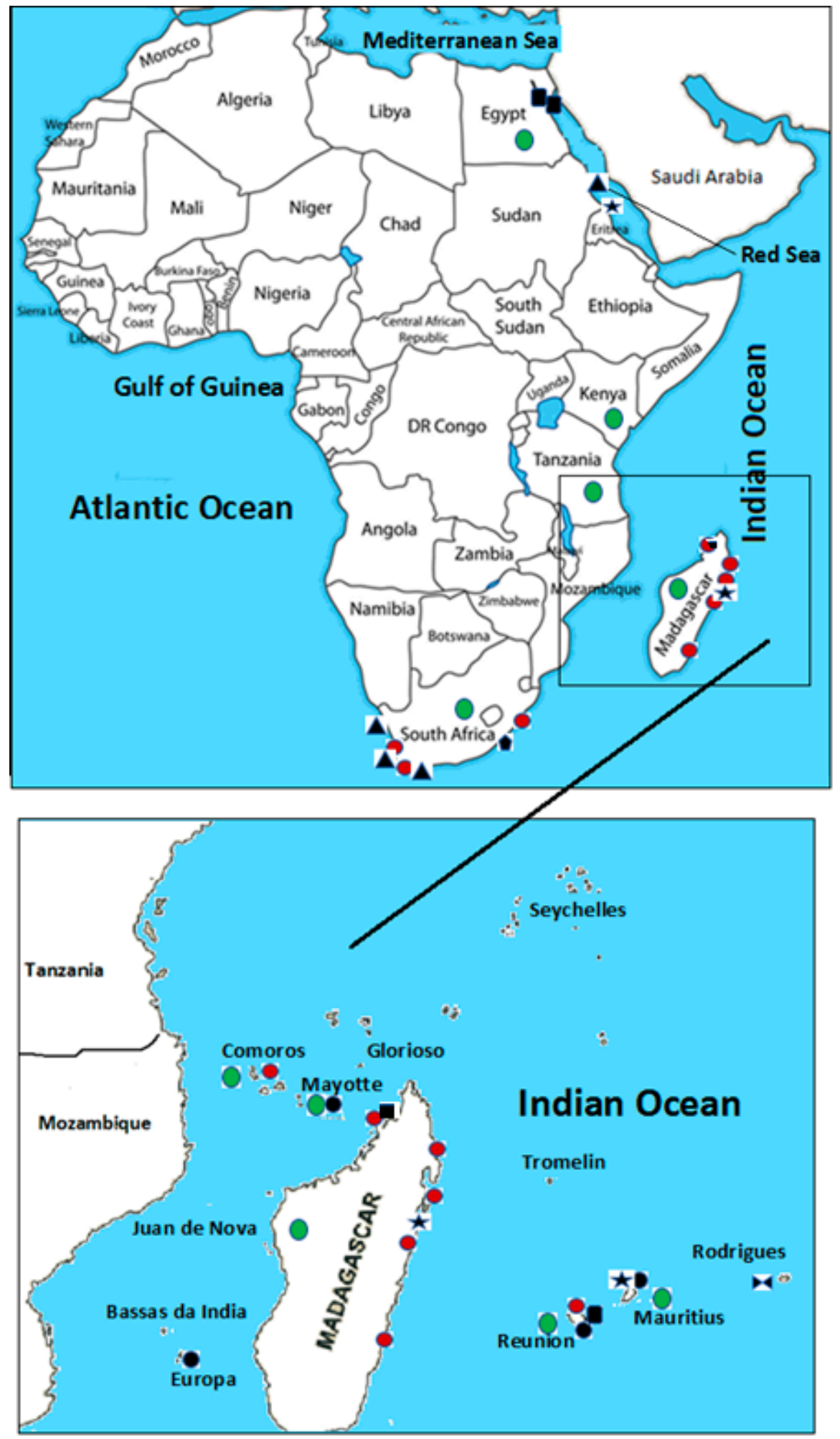

Figure 14. Map of the incidence of marine toxins (MT) along African countries of the Indian Ocean and the Red Sea, from EgypttoSouth Africa and nearby islands. Red circles [O]—confirmed or suspected seafood poisoning episodes caused by MT; green circles [O]-MT or Harmful Algal Blooms monitoring programmes or Centers of seafood poisonings; $\mathbf{A}$-Saxitoxins group; - Okadaic Acid group; $\star$-Ciguatoxin group; 1 -Palytoxin group; -Domoic Acid group and $\mathbf{D}$-Tetrodotoxin group. 


\subsection{South Africa}

The occurrence of species of phytoplankton including MTs-producing HABs has been reported in coastal waters of South Africa through scientific reports and environmental monitoring programmes since 2011 [324]. Reported producer species include cyanobacteria (Microcystisaeruginosa, Oscillatoria sp., Trichodesmium sp.), dinoflagellates (Dinophysisacuminata, D. rotundata, Alexandrium catenella, A. minutum, Gymnodinium sp., Prorocentrum sp., Gambierdiscustoxicus, Ostreopsis siamensis, O. ovata, P. lima, P. concavum), diatoms (Pseudo-nitzschia multiseries) $[19,305,309,315,331-333]$ and bacteria (Vibrio parahaemolyticus) [298]. Seafood poisoning cases were also reported in South Africa caused by PSTs, DSPs, PITXs and GYM [19,216,309,334] (Table 3) after the consumption of mussels (Donax serra, Perna perna and Chloromytilus meridionalis) (Table 4) [37]. To minimize seafood poisoning by MTs, South Africa has implemented, through the Department of Agriculture, a program for MT monitoring in molluscan shellfish on all coasts (South African Molluscan Shellfish Monitoring and Control Programme) [324] (Table 2). This program was created based on the regulations of the European Commission (EC) Regulation, namely: Commission Regulation (EC) No 2074/2005, No 853/2004 and No 15/2011 where limit values are described for MTs and analytical techniques are advised to monitor shellfish [324].

Due to the absence of legislation regarding CTXs, currently, there is an absence of monitoring programs regarding this group in South Africa.Since the Indian Ocean is considered an endemic site of CTXs, this is a matter of major importance.

\subsection{Mozambique}

Studies related to HAB occurrence in Mozambique are very scarce and the few published works indicate the occurrence of dinoflagellates of the genus Alexandrium [313] and species of cyanobacteria (Phormidium ambiguum, Lyngbya majuscula, and Lyngbya cf. putealis) [307]. To date, due to the absence of a Monitoring Program and trained health staff to recognize specific symptoms of seafood poisoning in humans, there are no records of published data of MT occurrence or reports of seafood poisoning cases in this country.

\subsection{Tanzania}

Published studies indicate the occurrence of cyanobacteria, namely: Pseudanabaena sp., Spirulina labyrinthiformis, Spirulina sp., Leptolyngbya sp., Phormidium sp., Oscillatoria sp., Lyngbyaaestuarii, Lyngbya sp., Lyngbya majuscula, Nodularia sp., Synechococcus sp., Microcystis sp.; Dinoflagellates: Gambierdiscus toxicus, Procentrum sp. and diatoms: Pseudo-nitzschia sp., Pseudo-nitzschia pungens, P. seriata and P. cuspidate [335-341]. Data related to MTs and seafood poisoning episodes are very scarce in Tanzania. In 2003, the Tanzanian government created guidelines for investigation and control of foodborne diseases and the regulatory institution is the Tanzania Food and Drugs Authority (TFDA) (Table 2) [325]. The main objective of TFDA is to regulate matters related to food quality and safety for consumers through the dissemination of the information related to causative agents, latency period [duration], principal symptoms, typical vectors, and prevention of poisoning as measures of public health protection [325]. Among several foodborne disease sources, MTs such as CTXs, TTXs, DA, and PSTs are described by TFDA. The creation of alert and monitoring programs is an effective way to prevent poisoning episodes caused by MT-contaminated seafood.

\subsection{Kenya}

In order to reduce the cases of seafood poisoning caused by MTs, the Kenya Marine and Fisheries Research has carried out projects funded by governmental and non-governmental institutions for monitoring levels of HABs and their toxins (Table 2) in coastal waters and shellfish as well as the possible transfer in the trophic food web [326].Since October 2017, there is an ongoing project called: The occurrence and distribution of HABS in East and South Africa (BIOTOXINS Research 
Project] funded by National Commission for Science, Technology and Innovation (NACOSTI) at Mombasa Research Center [326]. This project will cover a period of 2 years, which is not enough for long-termmonitoring. In these coastal waters were reported to occur several species of diatoms: Nitzschia sp., N. closterium, N. longisigma, N. sigma, Pseudo-nitzschia sp. Guinardia sp., G. striata, G.delicatula, Skeletonema sp, Leptocylindrus sp., Rhizosolenia sp., Cerataulina sp., Coscinodiscus sp., Thalassiosira sp., Corethron sp., C. criopilum, C. cenofemus and Chaetoceros sp.; dinoflagellates: Alexandrium sp., Dinophysis sp., D. caudata, Gambierdiscus sp., G. toxicus, Gonyaulax sp., Gymnodinium sp., Gyrodinium sp., Ostreopsis sp., Peridinium sp., Prorocentrum sp., Ceratium sp., C. fusus, C. furca, Noctiluca sp., N. scintillans, Protoperidinium sp., Scrippsiella sp. and S. trochoidea [301,310]. Cyanobacteria were also reported: Lyngbya sp., Oscillatoria sp., Fischerella epiphytica, Anabaena sp., Nodularia spumigena, Umezakia natans, Aphanizomenon flos-aquae, Microcystis aeruginosa and Trichodesmium sp. [342].

\subsection{Madagascar}

Madagascar is the country with more records of published data regarding MT occurrence (Figure 14) and consequently, many reported cases of seafood poisoning [36,47,49,343]. The seafood poisoning cases in Madagascar have been registered since 1930 mainly after the consumption of fish of the family Sphyrnidae, Cacharinidae, Clupeidae (herrings, sardines), and marine turtles species (Eretmochelys imbricata and Chelonia mydas) $[36,47,49,343]$. The main marine poisoning causative agents reported are CTXs, TTXs, and PITXs [18,344] (Table 4). To reduce the number of seafood poisoning events, the MadagascarMinistry of Health has created a Seafood Poisoning National Control Program (Table 2) based on the setting of an epidemiological surveillance network, prevention of the communities through educational programs and the development of research on marine eco-environment [327].

\subsection{Indian Ocean French Islands}

Mayotte, Europa, Banc du Geyser, Bassas da India, Glorioso, Juan de Nova, Reunion and Tromelin islands administratively make part in the French government but since they are in the Indian Ocean, were considered for the present study. In these islands, there are reports of the occurrence of HABs and cases of seafood poisoning linked to MTs. The reported HAB forming species include: dinoflagellates (Prorocentrum lima, P. convacum, Ostreopsis ovata, Gambierdiscus toxicus, Alexandrium spp.), cyanobacteria (Hydrocoleum sp., Lyngbya majuscula, Phormidium sp., Leptolyngbya sp. and Oscillatoria sp.) $[70,300,317,319,345]$. The recorded human intoxications were due to DSTs and TTXs $[35,328]$ (Table 4). Centers of Disease for control and Preventing is the organization responsible for National Biomonitoring Program of toxins (PSTs) in these islands [35,328] (Table 2).

\subsection{Mauritius}

In Mauritius there are registered cases of seafood poisoning caused mainly by CTXs [346] after the consumption of reeffish (Lutjanus sebae) [70,71,71] (Table 4). The Ministry of Ocean Economy, Marine Resources, Fisheries and Shipping of Mauritius is the institute responsible for themonitoring of HABs (Table 2) [347,348], developing several activities and reporting the principal vectors species involved in seafood poisoning, namely: fish (Variola louti, Plectroponus maculatus, ceragidae, Vieille loutre, V. plate, V. cuisinier, Lutjanus gibbus, L. sebae, L. monostigmus, L. bohar, Anyperodon leucogramnicus, Harengula ovalis, Sphyraena barracuda, Synancela verrucose, Remora remora, Lactoria carnuta, Diodon hystrix), turtles (Eretmochelys imbricate), crabs (Carpillus maculatus), sea-urchins (Echinothrix sp.) and bivalves (Tridaena sp.) [348].

HAB producers recorded in Mauritius include several dinoflagellates species (Ostreopsis mascarenensis, Gambierdiscus toxicus Adachi \& Fukuyo, Ostreopsis ovata Fukuyo, Ostreopsis siamensis, O. mascarenensis, Prorocentrum lima, P. concavum, P. hoffmanianum, Amphidinium sp., A. carterae, Coolia sp., Sinophysis sp., Gymnodinium sp., Gonyaulax sp., and Alexandrium sp.), diatoms (Pseudo-nitzschia sp.) 
and cyanobacteria (Phormidium sp., Oscillatoria sp. and Lyngbya sp., Phormidium sp., Oscillatoria sp. and Lyngbya sp.) [308].

\subsection{The Archipelago of Comoros}

Published data of the archipelago of Comoros indicate the occurrence of Gambierdiscus toxicus, G. yasumotoi, G. belizeanus, Prorocentrum arenarium, P. maculosum, P. belizeanum, P. lima, P. mexicanum, P. hoffmanianum, P. concavum, P. emarginatum, P. elegans, P. sp., Ostreopsis caribbeanus, O. mascarenensis, O. ovata O. heptagona, O. labens, O. siamensis, O. lenticularis, O. marinus, Cooliamonotis, C. tropicalis, Sinophysis microcephalus, S. canaliculate and Amphidiniopsis sp. [10,300]. Suspected seafood poisoning episodes linked to MTs were registered in the archipelago of Comoros after the consumption of turtle Eretmochelys imbricate with symptomatology similar to CFP [26], suggesting the presence of CTXs (Table 4).

\subsection{Somalia and Seychelles}

There are no published studies related to the occurrence of HABs and MTs in Somalia and Seychelles. While there are no published reports of HABs or MTs in Somalia and Seychelles waters, the proximity to other countries with such reports and currents in the area suggest that investigations are necessary to avoid potential seafood poisoning events [62]. 
Table 3. Geographic occurrence MT per country, MT producer, and MT vector along African countries of the Indian ocean and red sea coasts. TX - toxin.

\begin{tabular}{|c|c|c|c|c|c|c|c|c|}
\hline Toxin & Date & Location & Toxin Producer & Determination Method & Toxin Vector & $\begin{array}{c}\text { TX Concentration, } \\
\text { (mg TX Equivalents } \\
\text { per Kg Shellfish } \\
\text { Meat) }\end{array}$ & Cell/Extract Toxicity & Reference \\
\hline \multirow{5}{*}{ PSTs } & 1999 & South Africa & Alexandrium catenella & AOAC mouse bioassay & Haliotis midae & 0. 01609 STX & & [22] \\
\hline & \multirow[b]{2}{*}{ 1998-2002 } & \multirow[b]{2}{*}{ South Africa: Yzerfontein, } & Alexandrium catenella & \multirow[b]{2}{*}{ HPLC-FLD } & \multirow{2}{*}{ 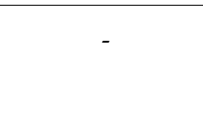 } & \multirow[t]{2}{*}{-} & 4.8 pg STX eq cell ${ }^{-1}$ & \multirow[b]{2}{*}{ [334] } \\
\hline & & & $\begin{array}{l}\text { Alexandrium } \\
\text { tamiyavanichi }\end{array}$ & & & & 0.14 pg STX eq cell ${ }^{-1}$ & \\
\hline & 2003-2004 & South Africa: Cape Town & Alexandrium minutum & $\begin{array}{l}\text { LC-FD and } \\
\text { HILIC-MS/MS }\end{array}$ & - & - & $0.65 \mathrm{pg}$ GTX cell ${ }^{-1}$ & [309] \\
\hline & 2012-2014 & $\begin{array}{l}\text { Central } \\
\text { Red Sea }\end{array}$ & $\begin{array}{c}\text { Pyrodinium bahamense, } \\
\text { Ceratium sp., } \\
\text { Alexandrium sp. and } \\
\text { Protoperidinium spp. }\end{array}$ & ELISA & - & - & $>0.4 \mathrm{ng} \mathrm{mL}^{1}$ & [349] \\
\hline \multirow{8}{*}{ DSTs } & \multirow{4}{*}{2000} & \multirow{4}{*}{$\begin{array}{l}\text { Europa Island Mozambic } \\
\text { channel, France] }\end{array}$} & \multirow{4}{*}{ Prorocentrum arenarium } & FR3T3 fibroblast & \multirow{4}{*}{-} & \multirow{4}{*}{-} & $\begin{array}{l}\mathrm{IC}_{50}=0,1 \mu \mathrm{g} \mathrm{OA} \mathrm{m} l^{-1} \\
\text { and } 50 \mu \mathrm{g} \text { extract ml } \\
-1\end{array}$ & \multirow{4}{*}{ [11] } \\
\hline & & & & PPIA & & & & \\
\hline & & & & HPLC-FD & & & & \\
\hline & & & & HPLC-MS & & & $22 \mathrm{ng} \mathrm{OA} / \mathrm{mg}$ of extract & \\
\hline & 2001 & $\begin{array}{c}\text { Lagoons of La Reunion } \\
\text { Mayotte and Mauritius } \\
\text { Islands }\end{array}$ & $\begin{array}{l}\text { Prorocentrum } \\
\quad \text { lima }\end{array}$ & PPIA & - & - & $\begin{array}{c}\mathrm{IC}_{50} 1.3-25 \mathrm{mg} / \mathrm{mL} \\
\text { onon fibroblast; } 6261.3 \\
\pm 156.5-128.3 \pm 17.2 \\
\text { ng eq OA } / \mathrm{mg} \\
\text { crudeextract }\end{array}$ & {$[328]$} \\
\hline & 2002-2018 & South Africa:Abalgold & - & - & Haliotis asinina & - & - & [324] \\
\hline & \multirow{2}{*}{2008} & \multirow{2}{*}{$\begin{array}{l}\text { South Africa: Saldanha Bay } \\
\text { and } \\
\text { Lambert's Bay }\end{array}$} & \multirow{2}{*}{ Dinophysis acuminata } & \multirow{2}{*}{ LC-MS/MS } & Crassostrea gigas & $0.267 \mathrm{OA}$ & & \\
\hline & & & & & $\begin{array}{l}\text { Choromytilus } \\
\text { meridionalis }\end{array}$ & $0.012 \mathrm{OA}$ & & \\
\hline
\end{tabular}


Table 3. Cont

\begin{tabular}{|c|c|c|c|c|c|c|c|c|}
\hline Toxin & Date & Location & Toxin Producer & Determination Method & Toxin Vector & $\begin{array}{c}\text { TX Concentration, } \\
\text { (mg TX Equivalents } \\
\text { per Kg Shellfish } \\
\text { Meat) }\end{array}$ & Cell/Extract Toxicity & Reference \\
\hline \multirow{7}{*}{ CTXs } & 2001 & $\begin{array}{l}\text { Mauritius: Nazareth, Saya } \\
\text { de Malha and Soudan }\end{array}$ & - & $\begin{array}{l}\text { HPLC-MS/RLB, } \\
\text { Mongoose feeding test, } \\
\text { and MBA }\end{array}$ & $\begin{array}{c}\text { Lutjanus sebae and } \\
\text { Lutjanus } \\
\text { Lab }\end{array}$ & Qualitative analysis & - & [71] \\
\hline & 2002 & $\begin{array}{l}\text { North of the Republic } \\
\text { of Mauritius, Banks fishery }\end{array}$ & - & HPLC-MS/RLB & Lutjanus sebae & & - & [70] \\
\hline & $2012-2013$ & Central Red Sea & $\begin{array}{c}\text { Gambierdiscus belizeanus } \\
\text { and } \\
\text { Ostreopsis spp. }\end{array}$ & $\begin{array}{l}\text { Mouse neuroblastoma } \\
\text { cell-based assay }\end{array}$ & - & - & $\begin{array}{l}\text { 6,50-1,14.10-5 pg } \\
\text { P-CTX }{ }^{-1} \text { eq. cell }\end{array}$ & [350] \\
\hline & \multirow{4}{*}{2013} & \multirow{4}{*}{$\begin{array}{l}\text { Madagascar: district of } \\
\text { Fenoarivo Atsinanana }\end{array}$} & \multirow{4}{*}{ Gambierdiscus spp. } & CBA & \multirow{4}{*}{ Carcharhinus leucas } & $\begin{array}{c}0.083 \\
\text { P-CTX-1 }\end{array}$ & \multirow{4}{*}{-} & \multirow{4}{*}{ [20] } \\
\hline & & & & MBA & & 0. 09272 P-CTX-1 & & \\
\hline & & & & LC-ESI-HRMS & & 0. 01628 P-СTX-1 & & \\
\hline & & & & MBA & & $752 \mathrm{MU} / \mathrm{g}$ & & \\
\hline \multirow{7}{*}{ PITXs } & \multirow{4}{*}{1994} & \multirow{4}{*}{$\begin{array}{c}\text { Madagascar: } \\
\text { Antalaha District }\end{array}$} & \multirow{4}{*}{ Ostreopsis siamensis } & MBA & \multirow{4}{*}{$\begin{array}{l}\text { Herklotsichthys } \\
\text { quadrimaculatus }\end{array}$} & $\begin{array}{c}\text { 0. } 00045 \text { PTXs/fish } \\
\text { [head and esophagus] }\end{array}$ & & \multirow{4}{*}{ [18] } \\
\hline & & & & Hemolysis assays & & $\begin{array}{c}\text { 0. } 00002 \text { PTXs/fish } \\
\text { [head and esophagus] }\end{array}$ & & \\
\hline & & & & Cytotoxicity tests & & $\begin{array}{c}\text { 0. 00000005/fish } \\
\text { [head and esophagus] }\end{array}$ & & \\
\hline & & & & MS & & & & \\
\hline & \multirow[t]{3}{*}{1996} & \multirow[t]{3}{*}{$\begin{array}{l}\text { Mauritius: Rodrigues } \\
\text { Island }\end{array}$} & \multirow[t]{3}{*}{ Ostreopsis mascarenensis } & $\begin{array}{l}\text { HPLC-diode array } \\
\text { detector, } \\
\text { Nanoelectrospray } \\
\text { ionization quadrupole } \\
\text { time-of-flight and } \\
\text { HPLC-ESI-MS/MS } \\
\text { analysis }\end{array}$ & - & - & & \multirow[t]{3}{*}[14,160]{} \\
\hline & & & & Hemolysis assays & & & $\begin{array}{c}8.00 \pm 0.01 \mathrm{ng} \text { PTX } \\
\mathrm{mL}^{-1}\end{array}$ & \\
\hline & & & & Cytotoxicity Assay & & & $\begin{array}{c}\text { IC50 }=10 \mu \mathrm{M} \text { against } \\
\text { human H460 lung } \\
\text { cancer cells }\end{array}$ & \\
\hline
\end{tabular}


Table 3. Cont

\begin{tabular}{|c|c|c|c|c|c|c|c|c|}
\hline Toxin & Date & Location & Toxin Producer & Determination Method & Toxin Vector & $\begin{array}{c}\text { TX Concentration, } \\
\text { (mg TX Equivalents } \\
\text { per Kg Shellfish } \\
\text { Meat) }\end{array}$ & Cell/Extract Toxicity & Reference \\
\hline & \multirow{2}{*}{2008} & \multirow{2}{*}{$\begin{array}{c}\text { South Africa: Saldanha Bay } \\
\text { and } \\
\text { Lambert's Bay }\end{array}$} & \multirow{2}{*}{ Dinophysis acuminata } & \multirow{2}{*}{ LC-MS/MS } & Crassostrea gigas & $0.267 \mathrm{OA}$ & & \\
\hline & & & & & $\begin{array}{l}\text { Choromytilus } \\
\text { meridionalis }\end{array}$ & $0.012 \mathrm{OA}$ & & \\
\hline \multirow[t]{2}{*}{ DA cultures } & \multirow{2}{*}{2012} & \multirow[t]{2}{*}{ South Africa: Algoa Bay } & \multirow{2}{*}{$\begin{array}{l}\text { Pseudo-nitzschia } \\
\text { multiseries }\end{array}$} & ELISA & \multirow[t]{2}{*}{-} & \multirow[t]{2}{*}{ - } & $\begin{array}{c}0.076 \mathrm{pg} \text { DA } \\
\text { cell }^{-1}-0.098 \mathrm{pg} \text { DA } \\
\text { cell }^{-1}\end{array}$ & \multirow[t]{2}{*}{ [12] } \\
\hline & & & & LC/MS-MS & & & $\begin{array}{c}0.086 \mathrm{pg} \text { DA } \\
\text { cell }^{-1}-0.086 \text { pg DA } \\
\text { cell }^{-1}\end{array}$ & \\
\hline \multirow{5}{*}{ TTXs } & \multirow[t]{2}{*}{ 1990-1991 } & \multirow{2}{*}{$\begin{array}{l}\text { Egypt: Suez City, in the } \\
\text { northwestern } \\
\text { part of the Red Sea }\end{array}$} & & $\begin{array}{l}\text { TLC, electrophoresis, UV, } \\
\text { GC-MS }\end{array}$ & \multirow{2}{*}{$\begin{array}{c}\text { Pleuranacanthus } \\
\text { sceleratus }\end{array}$} & \multirow{2}{*}{$752 \mathrm{MU} / \mathrm{g}$} & & \multirow{2}{*}[316]{} \\
\hline & & & & MBA & & & & \\
\hline & 1998 & $\begin{array}{l}\text { Madagascar: Nosy Be } \\
\text { Island - }\end{array}$ & - & MBA & & $16 \mathrm{MU} / \mathrm{g}$ & & [41] \\
\hline & 2002-2003 & Egypt: Gulf of Suez & & MBA & Lagocephalus sceleratus & $\begin{array}{c}3950 \\
\mathrm{MU} / \mathrm{g}\end{array}$ & & [351] \\
\hline & 2013 & Reunion Island & & MBA and LC-MS/MS & Lagocephalus sceleratus & 17 TTX & - & [35] \\
\hline
\end{tabular}




\subsection{Mediterranean and Red Sea (Djibouti, Eritrea, Sudan, Egypt)}

Several research works related to MTs are carried out in the Red Sea but are very limited on the African coast. Saudi Arabia is the country with the most published studies related to the occurrence of HABs along the Red Sea $[13,308,311,316,321,322,352,353]$. The Dinoflagellates (Alexandrium sp., Dinophysis sp., Prorocentrum sp., Pyrodinium sp., Gymnodinium sp.), cyanobacteria (Lyngbya sp., Oscillatoria sp., Trichodesmium sp.) and diatoms (Pseudonitzschia spp.) are the most reported marine producer species $[13,308,311,316,321,322,352,353]$. The bacteria Vibrio paraehemolyticus, producer of TTX, was detected in shrimp (Penaeus latisulcatus) in the Suez Gulf [299]. MTs reported in the Red Sea, mainly the Egyptian coast, described in Tables 3 and 4, include CTXs, TTXs, PSTs detected in puffer fish such as Pleuranacanthus sceleratus and Lagocephalus sceleratus [13,316,349-353]. Cases of seafood poisoning caused by CTXs and TTXs were reported, and according to the Poison Control Center, affiliated with Ain Shams University (Cairo, Egypt), CTXs are the third most responsible agents that induce food poisoning in Egypt [354]. Puffer fish poisoning has been recorded since ancient Egyptian times [42]. In Egypt, there is monitoring ofHABs in aquatic ecosystems since 1994 when Egypt became a member of the Convention on Biological Diversity although the Nature Conservation Sector, Egyptian Environment Affairs Agency and the Ministry of State for Environmental Affairs (Table 2) are focal points [330]. There are no reports of HABs and MT occurrence in coastal areas of Dibouti, Eritrea, and Sudan. 
Table 4. Seafood poisoning episodes caused by MTs, observed effects/Symptoms, fish or shellfish consumed and victim number affected along African countries of the Indian Ocean and Red sea coasts. TX - Toxin

\begin{tabular}{|c|c|c|c|c|c|c|c|c|}
\hline Local & Date & Seafood & Observed Effects/Symptoms & $\mathrm{TX}$ & $\begin{array}{l}\text { Detection } \\
\text { Method }\end{array}$ & $\begin{array}{l}\text { TX Concentration, } \\
\text { (mg TX } \\
\text { Equivalents/Kg } \\
\text { Shellfish Meat) }\end{array}$ & Victim Number & Reference \\
\hline $\begin{array}{l}\text { Comoros islands: } \\
\text { Ndrondroni }\end{array}$ & $\begin{array}{l}24 \text { December } \\
2012\end{array}$ & $\begin{array}{l}\text { Eretmochelys } \\
\text { imbricata } \\
\text { (turtle) }\end{array}$ & $\begin{array}{l}\text { Itching, Asthenia, Vomiting, Abdominal } \\
\text { pain, Rash Myalgia } \\
\text { Shortness of breath, Nausea } \\
\text { Itching of the mouth/throat, Fever, Diarrhea } \\
\text { Vertigo, Paresthesia, Dysphagia } \\
\text { Mouth burn Sore throat, Erectile } \\
\text { dysfunction } \\
\end{array}$ & - & - & - & $\begin{array}{l}49 \text { suspected cases } \\
\text { and } 8 \text { probable cases, } \\
\text { age range [0-40 } \\
\text { years], } 1 \text { death }\end{array}$ & [26] \\
\hline $\begin{array}{l}\text { North-eastern coast of } \\
\text { Madagascar }\end{array}$ & December 1994 & Turtle & $\begin{array}{l}\text { Nausea, vomiting, dysphagia, acute } \\
\text { stomatitis }\end{array}$ & - & - & - & $\begin{array}{c}60 \text { persons with } \\
\text { poisoning attack rate } \\
\text { were } 48 \% \text { with a } \\
\text { lethality of } 7.7 \%\end{array}$ & [47], \\
\hline \multirow[t]{2}{*}{$\begin{array}{l}\text { Madagascar: district } \\
\text { of Fenoarivo } \\
\text { Atsinanana }\end{array}$} & November 2013 & $\begin{array}{l}\text { Carcharhinus } \\
\text { leucas (shark) }\end{array}$ & $\begin{array}{l}\text { Paresthesia of the extremities, dysesthesia, } \\
\text { and reversing sensitivity of hot and cold } \\
\text { accompanied by a headache, dizziness, and } \\
\text { arthralgia between } 2 \text { and } 12 \mathrm{~h} \text { after ingestion }\end{array}$ & CTXs & MBA & $\begin{array}{c}0.083 \\
\text { P-CTX-1 }\end{array}$ & \multirow[t]{2}{*}{124 people, $9 \%$ deaths } & \multirow[t]{2}{*}{ [20] } \\
\hline & & & & & $\mathrm{CBA}$ & 0. 09272 P-CTX-1 & & \\
\hline \multirow{3}{*}{$\begin{array}{c}\text { Madagascar: } \\
\text { Antalaha District }\end{array}$} & \multirow{3}{*}{ January 1994} & \multirow{3}{*}{$\begin{array}{l}\text { Herklotsichthys } \\
\text { quadrimaculatus } \\
\text { (Fish) }\end{array}$} & \multirow{3}{*}{$\begin{array}{l}\text { Malaise, uncontrollable vomiting, diarrhea, } \\
\text { tinglings of extremities, } \\
\text { delirium and death }\end{array}$} & \multirow{2}{*}{ PITXs } & MBA & $\begin{array}{c}\text { 0. } 00045 \text { PTXs/fish } \\
\text { [head and esophagus] }\end{array}$ & \multirow{3}{*}{ Death of one adult } & \multirow{3}{*}{ [18] } \\
\hline & & & & & $\begin{array}{l}\text { Cytotoxicity } \\
\text { tests }\end{array}$ & $\begin{array}{c}0.00000005 / \text { fish } \\
\text { (head and esophagus) }\end{array}$ & & \\
\hline & & & & & $\begin{array}{c}\text { Mass } \\
\text { spectroscopy }\end{array}$ & - & & \\
\hline $\begin{array}{l}\text { Madagascar: Nosy Be } \\
\text { Island }\end{array}$ & July 1998 & - & - & TTXs & MBA & $\begin{array}{l}16 \mathrm{MU} / \mathrm{g} \text { (no data to } \\
\text { covert to } \mathrm{mg} / \mathrm{Kg} \text { ) }\end{array}$ & 4 people, one death & [41] \\
\hline
\end{tabular}


Table 4. Cont.

\begin{tabular}{|c|c|c|c|c|c|c|c|c|}
\hline Local & Date & Seafood & Observed Effects/Symptoms & $\mathrm{TX}$ & $\begin{array}{l}\text { Detection } \\
\text { Method }\end{array}$ & $\begin{array}{l}\text { TX Concentration, } \\
\text { (mg TX } \\
\text { Equivalents/Kg } \\
\text { Shellfish Meat) }\end{array}$ & Victim Number & Reference \\
\hline $\begin{array}{l}\text { Madagascar: } \\
\text { Manakara district }\end{array}$ & November 1993 & $\begin{array}{l}\text { Carcharhinus } \\
\text { amboinensis } \\
\text { [shark] }\end{array}$ & $\begin{array}{c}\text { Deep coma and death, } \\
\text { body rigidity due to loss of cerebral } \\
\text { function, } \\
\text { myosis, mydriasis, } \\
\text { convulsions, Respiratory distress due to } \\
\text { acute pulmonary edema, cardiovascular } \\
\text { collapse, bradycardia, gengivorrhagia } \\
\text { Dehydration, paresthesia on fingertips and } \\
\text { toes, dizziness, } \\
\text { pruritus, narcosis, faintness, hyperthermia, } \\
\text { ataiaia asthenia, dehydration, cephalalgia, } \\
\text { diarrhea, epigastralgia, laryngeal distress }\end{array}$ & CTXs & $\begin{array}{c}\text { Ciguatera } \\
\text { poisoning } \\
\text { Symptomology }\end{array}$ & - & $\begin{array}{l}500 \text { people, } 20 \% \\
\text { deaths }\end{array}$ & [21] \\
\hline $\begin{array}{c}\text { South Africa: Cape } \\
\text { Town }\end{array}$ & May 1978 & $\begin{array}{l}\text { Choromytilus } \\
\text { meridionlis } \\
\text { [Mussel] }\end{array}$ & $\begin{array}{c}\text { Paraesthesia of en } \\
\text { fingers/hands, Circumoral paresthesia, } \\
\text { paranesthesia of toes/feet, Vertigo, Floating } \\
\text { sensation, Ataxia, Weakness of upper, } \\
\text { Weakness of lower limbs and Dysarthria } \\
\text { A headache }\end{array}$ & PSTs & MBA & $72.83 \mathrm{STX}$ & 17 people, no deaths & [39] \\
\hline $\begin{array}{l}\text { South Africa: Natal } \\
\text { coast }\end{array}$ & December 1957 & $\begin{array}{l}\text { Mytilus } \\
\text { meridionalis } \\
\text { [Mussel] }\end{array}$ & $\begin{array}{c}\text { peculiar } \\
\text { lightness of the body, with a tingling around } \\
\text { mouth, finger, and toes; no moving; feeble } \\
\text { inarticulate noise; }\end{array}$ & PSTs & MBA & $0.04 \mathrm{STX}$ & 5 people and one cat & [40] \\
\hline $\begin{array}{l}\text { South Africa: Table } \\
\text { and False Bays }\end{array}$ & 1888 & $\begin{array}{l}\text { Donax serra } \\
\text { [Mussel] }\end{array}$ & - & - & - & - & & \multirow{4}{*}{ [37] } \\
\hline $\begin{array}{c}\text { South Africa: Cape } \\
\text { Town }\end{array}$ & April 1948 & $\begin{array}{l}\text { Donax serra } \\
\text { [Mussel] and } \\
\text { Chloromytilus } \\
\text { meridionalis } \\
\text { [Mussel] }\end{array}$ & - & - & - & - & One death & \\
\hline $\begin{array}{c}\text { South Africa: Natal } \\
\text { coast }\end{array}$ & December 1957 & $\begin{array}{l}\text { Perna perna } \\
\text { [Mussel] }\end{array}$ & - & - & - & - & 5 people, one death & \\
\hline $\begin{array}{c}\text { South Africa: Cape } \\
\text { Town a }\end{array}$ & May 1958 & $\begin{array}{l}\text { Chloromytilus } \\
\text { meridionalis } \\
\text { [Mussel] }\end{array}$ & - & - & & - & One death & \\
\hline Reunion Island & $\begin{array}{l}\text { September 10th, } \\
2013\end{array}$ & $\begin{array}{l}\text { Lagocephalus } \\
\text { sceleratus [fish] }\end{array}$ & $\begin{array}{l}\text { peri-oral paresthesia, weakness of both } \\
\text { lower limbs, paresthesia all over the body, } \\
\text { headache, dyspnea, } \\
\text { nausea and vomiting, blurring of vision, } \\
\text { and vertigo }\end{array}$ & TTX & MBA & $\begin{array}{l}\text { Liver: } 17 \text { TTX } \\
\text { Flesh: } 5 \text { TTX }\end{array}$ & 10 people & [35] \\
\hline
\end{tabular}




\section{Final Considerations and Recomendations}

African Indian Ocean and the Red Sea coasts have a subtropical and tropical climate, considered optimal for the development and transportation of several HAB-forming species, and consequently, the production of MTs. Paradoxically, studiesrelated to the occurrence and incidence of HABs and MTs are very limited, from South Africa to Egypt. From a few data available in this zone, most describe only the genus and not the full species, making it very difficult to evaluate the occurrence of the toxic species. The most reported HAB phytoplanktons in this region are cyanobacteria, followed by dinoflagellates, and diatoms as potential MT producers. Relative to MTs, the most reported and involved in seafood poisoning episodes include CTXs, PSTs, and TTXs. The scarcity of the data related to MTs suggests the need for further studies and the creation of specific monitoring programs of HABs, particularly for dinoflagellates and diatoms since these constitute the phytoplankton that produces more fatal MTs, though in recent years several genera of bacteria have been described as producers of a potent group of marine toxins, TTXs, which have already been detected on the African coasts of the Indian Ocean and Red Sea. The main MTs that must be monitored in shellfish are presented in Table 5. Analytical techniques such as LC-MS/MS are advised and recommended as determination and quantification methods due to their higher reproducibility, specificity, sensitivity and capacity to discriminate analogs of given toxins in the sample. The permitted limit of a toxin in shellfish can be adopted from other countries as an example to follow such as the EU region, USA, Japan, Australia, and New Zealand.

Table 5. Recommended marine toxins to be monitored and suggestion of permitted limit to be used.

\begin{tabular}{cccc}
\hline Toxin & Syndrome & Permitted Limit, $\mathbf{~ m K g ~}^{-\mathbf{1}}$ & To be adopted from \\
\hline STX & PSP & 0.8 STXeq & EU region \\
CTX & CFP & 0.00001 P-CTX-1eq & USA \\
YTX & - & 3.75 YTXeq & EU region \\
PTX & - & 0.16 OAeq & EU region \\
TTX & - & 2 TTeq & Japan \\
DA & ASP & 20 DAeq & EU region \\
OA & DSP & 0.16 OAeq & EU region \\
AZA & AZP & 0.16 AZAeq & EU region \\
PITX & - & 0.25 PlTXeq & EU region \\
PbTx & NSP & 0.8 TX-2 eq & USA, New Zealand, and Australia \\
\hline
\end{tabular}

${ }^{*}$ This toxin is not monitored and 0.25 PlTXeq was proposed in the first meeting (Cesenatico, Italy, 24-25 October 2005) of the working group on Toxicology of the national reference laboratories [NRLs] for Marine Biotoxins.

For the success of the MT monitoring programs, the integration and intercollaboration of environmental, public health and researches institutions and universities of the all African Countries of the Indian Ocean and the Red Sea is crucial.

Author Contributions: Conceptualization, V.V. and M.S.; Writing-Original Draft Preparation, I.J.T.; Writing-Review \& Editing, I.J.T, M.S. and V.V.; Supervision, V.V. and M.S.

Funding: This research was supported by the project Alertox-Net [EAPA-317-2016] of the Interreg Atlantic Area Program funded by the European Regional Development Fund and by the Portuguese Foundation of Science and Technology [FCT] project UID/Multi/04423/2013.

Acknowledgments: We acknowledge the project EMERTOX [grant 734748], funded by H2020-MSCA-RISE 2016.

Conflicts of Interest: The authors declare no conflict of interest.

\section{References}

1. Cembella, A.D.; Lewis, N.I.; Quilliam, M.A. The marine dinoflagellate Alexandrium ostenfeldii [Dinophyceae] as the causative organism of spirolide shellfish toxins. Phycologia 2000, 39, 67-74. [CrossRef]

2. MacKenzie, L.; de Salas, M.; Adamson, J.; Beuzenberg, V. The dinoflagellate genus Alexandrium [Halim] in New Zealand coastal waters: Comparative morphology, toxicity and molecular genetics. Harmful Algae 2004, 3, 71-92. [CrossRef] 
3. Beppu, R.; Nojima, K.; Tsuruda, S.; Gomez-Delan, G.; Barte-Quilantang, M.; Taniyama, S.; Sagara, T.; Nishio, S.; Takayama, H.; Miyazawa, K.; et al. Occurrence of PSP-producing dinoflagellate Alexandrium tamiyavanichii in Bingo-Nada, the central coastal water of the Seto Inland Sea, Hiroshima Prefecture, Japan. Mar. Pollut. Bull. 2008, 56, 758-763. [CrossRef] [PubMed]

4. Wang, D.-Z. Neurotoxins from marine dinoflagellates: A brief review. Mar. Drugs 2008, 6, 349-371. [CrossRef] [PubMed]

5. Seki, T.; Satake, M.; Mackenzie, L.; Kaspar, H.F.; Yasumoto, T. Gymnodimine, a new marine toxin of unprecedented structure isolated from New Zealand oysters and the dinoflagellate, Gymnodinium sp. Tetrahedron Lett. 1995, 36, 7093-7096. [CrossRef]

6. Draisci, R.; Lucentini, L.; Giannetti, L.; Boria, P.; Poletti, R. First report of pectenotoxin-2 [PTX-2] in algae [Dinophysis fortii] related to seafood poisoning in Europe. Toxicon 1996, 34, 923-935. [CrossRef]

7. Martin, J.L.; Hanke, A.R.; LeGresley, M.M. Long term phytoplankton monitoring, including harmful algal blooms, in the Bay of Fundy, eastern Canada. J. Sea Res. 2009, 61, 76-83. [CrossRef]

8. Jeffrey, L.C. Identification of DTX-4, a new water-soluble phosphatase inhibitor from the toxic dinoflagellate Prorocentrum lima. J. Chem. Soc. Chem. Commun. 1995, 597-599. [CrossRef]

9. MacKenzie, L.; Beuzenberg, V.; Holland, P.; McNabb, P.; Suzuki, T.; Selwood, A. Pectenotoxin and okadaic acid-based toxin profiles in Dinophysis acuta and Dinophysis acuminata from New Zealand. Harmful Algae 2005, 4, 75-85. [CrossRef]

10. Ten-Hage, L.; Turquet, J.; Quod, J.P.; Couté, A. Coolia areolata sp. nov. [Dinophyceae], a new sand-dwelling dinoflagellate from the southwestern Indian Ocean. Phycologia 2000, 39, 377-383. [CrossRef]

11. Ten-Hage, L.; Delaunay, N.; Pichon, V.; Couté, A.; Puiseux-Dao, S.; Turquet, J. Okadaic acid production from the marine benthic dinoflagellate Prorocentrum arenarium Faust [Dinophyceae] isolated from Europa Island coral reef ecosystem [SW Indian Ocean]. Toxicon 2000, 38, 1043-1054. [CrossRef]

12. Pitcher, G.C.; Cembella, A.D.; Krock, B.; Macey, B.M.; Mansfield, L.; Probyn, T.A. Identification of the marine diatom Pseudo-nitzschia multiseries [Bacillariophyceae] as a source of the toxin domoic acid in Algoa Bay, South Africa. Afr. J. Mar. Sci. 2014, 36, 523-528. [CrossRef]

13. Mohamed, Z.A.; Al-Shehri, A.M. Biodiversity and toxin production of cyanobacteria in mangrove swamps in the Red Sea off the southern coast of Saudi Arabia. Bot. Mar. 2015, 58, 23-34. [CrossRef]

14. Lenoir, S.; Ten-Hage, L.; Turquet, J.; Quod, J.; Bernard, C.; Hennion, M. First evidence of palytoxin analogues from an Ostreopsis mascarenensis (Dinophyceae) benthic bloom in Southwestern Indian Ocean. J. Phycol. 2004, 40, 1042-1051. [CrossRef]

15. Jørgensen, K.; Andersen, P. Relation between the concentration of Dinophysis acuminata and diarrheic shellfish poisoning toxins in blue mussels [Mytilus edulis] during a toxic episode in the Limfjord [Denmark], 2006. J. Shellfish Res. 2007, 26, 1081-1087. [CrossRef]

16. Landsberg, J.H.; Flewelling, L.J.; Naar, J. Karenia brevis red tides, brevetoxins in the food web, and impacts on natural resources: Decadal advancements. Harmful Algae 2009, 8, 598-607. [CrossRef]

17. El-Sayed, M.; Yacout, G.A.; El-Samra, M.; Ali, A.; Kotb, S.M. Toxicity of the Red Sea pufferfish Pleuranacanthus sceleratus “El-Karad. " Ecotoxicol. Environ. Saf. 2003, 56, 367-372. [CrossRef]

18. Onuma, Y.; Satake, M.; Ukena, T.; Roux, J.; Chanteau, S.; Rasolofonirina, N.; Ratsimaloto, M.; Naoki, H.; Yasumoto, T. Identification of putative palytoxin as the cause of clupeotoxism. Toxicon 1999, 37, 55-65. [CrossRef]

19. Pitcher, G.C.; Krock, B.; Cembella, A.D. Accumulation of diarrhetic shellfish poisoning toxins in the oyster Crassostrea gigas and the mussel Choromytilus meridionalis in the southern Benguela ecosystem. Afr. J. Mar. Sci. 2011, 33, 273-281. [CrossRef]

20. Diogène, J.; Reverté, L.; Rambla-Alegre, M.; Río, V.; Iglesia, P.; Campàs, M.; Palacios, O.; Flores, C.; Caixach, J.; Ralijaona, C.; et al. Identification of ciguatoxins in a shark involved in a fatal food poisoning in the Indian Ocean. Sci. Rep. 2017, 7, 8240. [CrossRef]

21. Habermehl, G.G.; Krebs, H.C.; Rasoanaivo, P.; Ramialiharisoa, A. Severe ciguatera poisoning in Madagascar: A case report. Toxicon 1994, 32, 1539-1542. [CrossRef]

22. Pitcher, G.C.; Franco, J.M.; Doucette, G.J.; Powell, C.L.; Mouton, A. Paralytic Shellfish Poisoning in the abalone Haliotis midae on the West Coast of South Africa. J. Shellfish Res. 2001, 20, 895-904. 
23. Silva, M.; Rodriguez, I.; Barreiro, A.; Kaufmann, M.; Neto, A.I.; Hassouani, M.; Sabour, B.; Alfonso, A.; Botana, L.M.; Vasconcelos, V. First report of ciguatoxins in two starfish species: Ophidiaster ophidianus and Marthasterias glacialis. Toxins 2015, 7, 3740-3757. [CrossRef] [PubMed]

24. Vale, P.; de M Sampayo, M.A. First confirmation of human diarrhoeic poisonings by okadaic acid esters after ingestion of razor clams [Solen marginatus] and green crabs [Carcinus maenas] in Aveiro lagoon, Portugal and detection of okadaic acid esters in phytoplankton. Toxicon 2002, 40, 989-996. [CrossRef]

25. Ahmed, S. Puffer fish tragedy in Bangladesh: An incident of Takifugu oblongus poisoning in Degholia, Khulna. Afr. J. Mar. Sci. 2006, 28, 457-458. [CrossRef]

26. Mbaé, S.B.A.; Mlindassé, M.; Mihidjaé, S.; Seyler, T. Food-poisoning outbreak and fatality following ingestion of sea turtle meat in the rural community of Ndrondroni, Mohéli Island, Comoros, December 2012. Toxicon 2016, 120, 38-41. [CrossRef] [PubMed]

27. Yong, Y.S.; Quek, L.S.; Lim, E.K.; Ngo, A. A case report of puffer fish poisoning in Singapore. Case Rep. Med. 2013. [CrossRef]

28. Hwang, P.-A.; Tsai, Y.-H.; Lu, Y.-H.; Hwang, D.-F. Paralytic toxins in three new gastropod [Olividae] species implicated in food poisoning in southern Taiwan. Toxicon 2003, 41, 529-533. [CrossRef]

29. Rafiqui Islam, M.; Chowdhury, F.R.; Das, S.K.; Rahman, S.; Mahmudur, M.D.; Amin, M.D.R. Outbreak of Puffer Fish Poisoning in Dhaka City. J. Med. 2018, 19, 30-34. [CrossRef]

30. Field, J. Puffer fish poisoning. Emerg. Med. J. 1998, 15, 334-336. [CrossRef]

31. Chopra, S.A. A case of fatal puffer-fish poisoning in a Zanzibari fisherman. East Afr. Med. J. 1967, 44, 493-496.

32. Ellis, R.; Jelinek, G.A. Never eat an ugly fish: Three cases of tetrodotoxin poisoning from Western Australia. Emerg. Med. 1997, 9, 136-142. [CrossRef]

33. Ghose, A.; Ahmed, H.; Basher, A.; Amin, M.R.; Sayeed, A.A.; Faiz, M.A. Tetrodotoxin poisoning in Blangadesh: A case study. J. Med. Toxicol. 2008, 4, 216.

34. Halstead, B.W.; Cox, K.W. An investigation on fish poisoning in Mauritius. Proc. R. Soc. Arts Sci. Maruritius 1973, 4, 1-26.

35. Puech, B.; Batsalle, B.; Roget, P.; Turquet, J.; Quod, J.-P.; Allyn, J.; Idoumbin, J.P.; Chane-Ming, J.; Villefranque, J.; Mougin-Damour, K.; et al. Family tetrodotoxin poisoning in Reunion Island [Southwest Indian Ocean] following the consumption of Lagocephalus sceleratus [Pufferfish]. Bull. Soc. Pathol. Exot. 2014, 107, 79-84. [CrossRef] [PubMed]

36. Ribes, G.C.; Ramarokoto, S.; Rabearintsoa, S.; Robinson, R.; Ranaivoson, G.; Rakotonjanabelo, L.A.; Rabeson, D. Seafood poisoning in Madagascar: Current state of knowledge and results of a retrospective study of the inhabitants of coastal villages [Internet]. Sante 1999, 9, 235-241. Available online: http://search. ebscohost.com/login.aspx?direct=true\&db=mnh\&AN=10623871\&site=eds-live (accessed on 20 June 2018). [PubMed]

37. Grindley, J.R.; Sapeika, N. The cause of mussel poisoning in South Africa. S. Afr. Med. J. 1969, 43, $275-279$.

38. Linlawan, S.; Suteparuk, S. Puffer fish poisoning from illicit fish trading in Bangkok, Thailand. J. Med. Toxicol. 2008, 4, 215.

39. Popkiss, M.E.; Horstman, D.A.; Harpur, D. Paralytic shellfish poisoning. A report of 17 cases in Cape Town. S. Afr. Med. J. Suid-Afrikaanse Tydskr vir Geneeskd 1979, 55, 1017-1023.

40. Mann, N.M.; Winship, W.S. Paralytic mussel poisoning in Natal. S. Afr. Med. J. 1958, 32, 548-549.

41. Ravaonindrina, N.; Andriamaso, T.H.; Rasolofonirina, N. Puffer fish poisoning in Madagascar: Four case reports. Arch. Inst. Pasteur Madag. 2001, 67, 61-64.

42. Jong, E.C. Fish and shellfish poisoning: Toxic syndromes. In The Travel and Tropical Medicine Manual; Jong, E.C., Sanford, C., Eds.; W.B. Saunders: Edinburgh, 2008; pp. 474-480.

43. Laurent, D.; Kerbrat, A.-S.; Darius, H.T.; Girard, E.; Golubic, S.; Benoit, E.; Sauviat, M.-P.; Chinain, M.; Molgo, J.; Pauillac, S.; et al. Are cyanobacteria involved in Ciguatera Fish Poisoning-like outbreaks in New Caledonia? Harmful Algae 2008, 7, 827-838. [CrossRef]

44. Ishida, H.; Muramatsu, N.; Nukaya, H.; Kosuge, T.; Tsuji, K. Study on neurotoxic shellfish poisoning involving the oyster, Crassostrea gigas, in New Zealand. Toxicon 1996, 34, 1050-1053. [CrossRef]

45. Boisier, P.; Ranaivoson, G.; Rasolofonirina, N.; Roux, J.; Chanteau, S.; Takeshi, Y. Fatal mass poisoning in Madagascar following ingestion of a shark [Carcharhinus leucas]: Clinical and epidemiological aspects and isolation of toxins. Toxicon 1995, 33, 1359-1364. [CrossRef] 
46. F.E.R. Paralytic shellfish poisoning in eastern canada: Prackash, A., Medcof, J. C. And Tennant, A.D. Fisheries research board of canada, bull. 71, ottawa, 1971, 88 p. Toxicon 1973, 11, 209-210. [CrossRef]

47. Ranaivoson, G.; de Ribes Champetier, G.; Mamy, E.R.; Jeannerod, G.; Razafinjato, P.; Chanteau, S. Mass food poisoning after eating sea turtle in the Antalaha district. Arch. Inst. Pasteur Madag. 1994, 61, 84-86.

48. Islam, Q.T.; Razzak, M.A.; Islam, M.A.; Bari, M.I.; Basher, A.; Chowdhury, F.R.; Sayeduzzaman, A.B.; Ahasan, H.A.; Faiz, M.A.; Arakawa, O.; et al. Puffer fish poisoning in Bangladesh: Clinical and toxicological results from large outbreaks in 2008. Trans. R. Soc. Trop. Med. Hyg. 2011, 105, 74-80. [CrossRef]

49. Champetier, D.R.G.; Rasolofonirina, R.N.; Ranaivoson, G.; Razafimahefa, N.; Rakotoson, J.D.; Rabeson, D. Intoxication by marine animal venoms in Madagascar [ichthyosarcotoxism and chelonitoxism]: Recent epidemiological data. Bull. Soc. Pathol. Exot. 1997, 90, 286-290.

50. Hallegraeff, G.M. A review of harmful algal blooms and their apparent global increase. Phycologia 1993, 32, 79-99. [CrossRef]

51. Council of the European Union; Council Directive 86/609/EEC of 24 November 1986 on the approximation of laws, regulations and administrative provisions of the Member States regarding the protection of animals used for experimental and other scientific purposes. Off. J. Eur. Commun. 1986, 29, L358.

52. Regulation, C. COMMISSION REGULATION [EU] No 15/2011 of 10 January 2011 amending Regulation [EC] No 2074/2005 as regards recognised testing methods for detecting marine biotoxins in live bivalve molluscs. Off. J. Eur. Commun. 2011, 50, 3-4.

53. Spatharis, S.; Dolapsakis, N.P.; Economou-Amilli, A.; Tsirtsis, G.; Danielidis, D.B. Dynamics of potentially harmful microalgae in a confined Mediterranean Gulf-Assessing the risk of bloom formation. Harmful Algae 2009, 8, 736-743. [CrossRef]

54. Raho, N.; Pizarro, G.; Escalera, L.; Reguera, B.; Marín, I. Morphology, toxin composition and molecular analysis of Dinophysis ovum Schütt, a dinoflagellate of the "Dinophysis acuminata complex". Harmful Algae 2008, 7, 839-848. [CrossRef]

55. Caroppo, C.; Congestri, R.; Bruno, M. On the presence of Phalacroma rotundatum in the southern Adriatic Sea [Italy]. Aquat. Microb. Ecol. 1999, 17, 301-310. [CrossRef]

56. McCarron, P.; Kilcoyne, J.; Hess, P. Effects of cooking and heat treatment on concentration and tissue distribution of okadaic acid and dinophysistoxin-2 in mussels [Mytilus edulis]. Toxicon 2008, 51, 1081-1089. [CrossRef] [PubMed]

57. Tanti, J.-F.; Gremeaux, T.; Van Obberghen, E.; Le Marchand-Brustel, Y. Effects of okadaic acid, an inhibitor of protein phosphatases-1 and-2A, on glucose transport and metabolism in skeletal muscle. J. Biol. Chem. 1991, 266, 2099-2103. [PubMed]

58. Louzao, M.C.; Vieytes, M.R.; Botana, L.M. Effect of okadaic acid on glucose regulation. Mini Rev. Med. Chem. 2005, 5, 207-215. [CrossRef]

59. Yasumoto, T.; Seino, N.; Murakami, Y.; Murata, M. Toxins produced by benthic dinoflagellates. Biol. Bull. 1987, 172, 128-131. [CrossRef]

60. Naoki, H.; Fujita, T.; Cruchet, P.; Legrand, A.M.; Igarashi, T.; Yasumoto, T. Structural determination of new ciguatoxin congeners by tandem mass spectrometry. In International IUPAC Symposium on Mycotoxins and Phycotoxins Ponsen E Looyen; Ponsen and Looijen: Wageningen, The Netherlands, 2001; pp. 475-482.

61. Lewis, R.J.; Sellin, M.; Poli, M.A.; Norton, R.S.; MacLeod, J.K.; Sheil, M.M. Purification and characterization of ciguatoxins from moray eel [Lycodontis javanicus, Muraenidae]. Toxicon 1991, 29, 1115-1127. [CrossRef]

62. Lewis, R.J. The changing face of ciguatera. Toxicon 2001, 39, 97-106. [CrossRef]

63. Lehane, L.; Lewis, R.J. Ciguatera: Recent advances but the risk remains. Int. J. Food Microbiol. 2000, 61, 91-125. [CrossRef]

64. Satake, M.; Murata, M.; Yasumoto, T. The structure of CTX3C, a ciguatoxin congener isolated from cultured Gambierdiscus toxicus. Tetrahedron Lett. 1993, 34, 1975-1978. [CrossRef]

65. Satake, M.; Murata, M.; Yasumoto, T. Gambierol: A new toxic polyether compound isolated from the marine dinoflagellate Gambierdiscus toxicus. J. Am. Chem. Soc. 1993, 115, 361-362. [CrossRef]

66. Satake, M.; Fukui, M.; Legrand, A.-M.; Cruchet, P.; Yasumoto, T. Isolation and structures of new ciguatoxin analogs, 2, 3-dihydroxyCTX3C and 51-hydroxyCTX3C, accumulated in tropical reef fish. Tetrahedron Lett. 1998, 39, 1197-1198. [CrossRef] 
67. Pottier, I.; Vernoux, J.-P.; Jones, A.; Lewis, R.J. Characterisation of multiple Caribbean ciguatoxins and congeners in individual specimens of horse-eye jack [Caranx latus] by high-performance liquid chromatography/mass spectrometry. Toxicon 2002, 40, 929-939. [CrossRef]

68. Bagnis, R.; Kuberski, T.; Laugier, S. Clinical observations on 3,009 cases of ciguatera [fish poisoning] in the South Pacific. Am. J. Trop. Med. Hyg. 1979, 28, 1067-1073. [CrossRef] [PubMed]

69. Lewis, R.J.; Vernoux, J.-P.; Brereton, I.M. Structure of Caribbean ciguatoxin isolated from Caranx latus. J. Am. Chem. Soc. 1998, 120, 5914-5920. [CrossRef]

70. Hamilton, B.; Hurbungs, M.; Jones, A.; Lewis, R.J. Multiple ciguatoxins present in Indian Ocean reef fish. Toxicon 2002, 40, 1347-1353. [CrossRef]

71. Hamilton, B.; Hurbungs, M.; Vernoux, J.-P.; Jones, A.; Lewis, R.J. Isolation and characterisation of Indian Ocean ciguatoxin. Toxicon 2002, 40, 685-693. [CrossRef]

72. Hokama, Y.; Abad, M.A.; Kimura, L.H. A rapid enzyme-immunoassay for the detection of ciguatoxin in contaminated fish tissues. Toxicon 1983, 21, 817-824. [CrossRef]

73. Panel, E.C. Scienti fi c opinion on marine biotoxins in shell fi sh-emerging toxins: Ciguatoxin-group toxins. EFSA Panel Contam. Food Chain EFSA J. 2010, 8, 1627-1638.

74. Pottier, I.; Vernoux, J.P.; Jones, A.; Lewis, R.J. Analysis of toxin profiles in three different fish species causing ciguatera fish poisoning in Guadeloupe, French West Indies. Food Addit. Contam. 2002, 19, 1034-1042. [CrossRef]

75. Mello, F.D.; Braidy, N.; Marcal, H.; Guillemin, G.; Nabavi, S.M.; Neilan, B.A. Mechanisms and effects posed by neurotoxic products of cyanobacteria/microbial eukaryotes/dinoflagellates in algae blooms: A review. Neurotox. Res. 2018, 33, 153-167. [CrossRef] [PubMed]

76. Touzet, N.; Franco, J.M.; Raine, R. Morphogenetic diversity and biotoxin composition of Alexandrium [Dinophyceae] in Irish coastal waters. Harmful Algae 2008, 7, 782-797. [CrossRef]

77. Miles, C.O.; Wilkins, A.L.; Stirling, D.J.; MacKenzie, A.L. Gymnodimine C, an isomer of gymnodimine B, from Karenia selliformis. J. Agric. Food Chem. 2003, 51, 4838-4840. [CrossRef] [PubMed]

78. Nézan, E.; Chomérat, N. Vulcanodinium rugosum gen. et sp. nov. [Dinophyceae], un nouveau dinoflagellé marin de la côte méditerranéenne française. Cryptogam. Algol. 2011, 32, 3-18. [CrossRef]

79. Selwood, A.I.; Miles, C.O.; Wilkins, A.L.; van Ginkel, R.; Munday, R.; Rise, F.; McNabb, P. Isolation, structural determination and acute toxicity of pinnatoxins E, F and G. J. Agric. Food Chem. 2010, 58, 6532-6542. [CrossRef] [PubMed]

80. Krock, B.; Tillmann, U.; John, U.; Cembella, A. LC-MS-MS aboard ship: Tandem mass spectrometry in the search for phycotoxins and novel toxigenic plankton from the North Sea. Anal. Bioanal. Chem. 2008, 392, 797-803. [CrossRef]

81. Gill, S.; Murphy, M.; Clausen, J.; Richard, D.; Quilliam, M.; MacKinnon, S.; LaBlanc, P.; Mueller, R.; Pulido, O. Neural injury biomarkers of novel shellfish toxins, spirolides: A pilot study using immunochemical and transcriptional analysis. Neurotoxicology 2003, 24, 593-604. [CrossRef]

82. Lawrence, J.; Loreal, H.; Toyofuku, H.; Hess, P.; Iddya, K. Assessment and Management of Biotoxin Risks in Bivalve Molluscs. 2011. Available online: https:/ / archimer.ifremer.fr/doc/00085/19588/ (accessed on 10 November 2018).

83. Silva, M.; Pratheepa, V.K.; Botana, L.M.; Vasconcelos, V. Emergent toxins in North Atlantic temperate waters: A challenge for monitoring programs and legislation. Toxins 2015, 7, 859-885. [CrossRef]

84. Cembella, A.; Krock, B. Cyclic Imine Toxins: Chemistry, Biogeography, Biosynthesis and Pharmacology. In Seaf Freshw toxins Pharmacol Physiol Detect; Botana, L.M., Ed.; CRC Press: Boca Raton, FL, USA, 2007; pp. 561-580.

85. Rundberget, T.; Aasen, J.A.B.; Selwood, A.I.; Miles, C.O. Pinnatoxins and spirolides in Norwegian blue mussels and seawater. Toxicon 2011, 58, 700-711. [CrossRef] [PubMed]

86. Otero, P.; Alfonso, A.; Alfonso, C.; Vieytes, M.R.; Louzao, M.C.; Botana, A.M.; Botana, L.M. New protocol to obtain spirolides from Alexandrium ostenfeldii cultures with high recovery and purity. Biomed. Chromatogr. 2010, 24, 878-886. [PubMed]

87. Watkins, S.M.; Reich, A.; Fleming, L.E.; Hammond, R. Neurotoxic shellfish poisoning. Mar. Drugs 2008, 6, 431-455. [CrossRef] [PubMed] 
88. Abraham, A.; Plakas, S.M.; Wang, Z.; Jester, E.L.E.; El Said, K.R.; Granade, H.R.; Henry, M.S.; Blum, P.C.; Pierce, R.H.; Dickey, R.W. Characterization of polar brevetoxin derivatives isolated from Karenia brevis cultures and natural blooms. Toxicon 2006, 48, 104-115. [CrossRef] [PubMed]

89. Dickey, R.; Jester, E.; Granade, R.; Mowdy, D.; Moncreiff, C.; Rebarchik, D.; Robl, M.; Musser, S.; Poli, M. Monitoring brevetoxins during a Gymnodinium breve red tide: Comparison of sodium channel specific cytotoxicity assay and mouse bioassay for determination of neurotoxic shellfish toxins in shellfish extracts. Nat. Toxins 1999, 7, 157-165. [CrossRef]

90. Ishida, H.; Nozawa, A.; Hamano, H.; Naoki, H.; Fujita, T.; Kaspar, H.F.; Tsuji, K. Brevetoxin B5, a new brevetoxin analog isolated from cockle Austrovenus stutchburyi in New Zealand, the marker for monitoring shellfish neurotoxicity. Tetrahedron Lett. 2004, 45, 29-33. [CrossRef]

91. Murata, M.; Legrand, A.M.; Ishibashi, Y.; Fukui, M.; Yasumoto, T. Structures and configurations of ciguatoxin from the moray eel Gymnothorax javanicus and its likely precursor from the dinoflagellate Gambierdiscus toxicus. J. Am. Chem. Soc. 1990, 112, 4380-4386. [CrossRef]

92. Morohashi, A.; Satake, M.; Murata, K.; Naoki, H.; Kaspar, H.F.; Yasumoto, T. Brevetoxin B3, a new brevetoxin analog isolated from the greenshell mussel Perna canaliculus involved in neurotoxic shellfish poisoning in New Zealand. Tetrahedron Lett. 1995, 36, 8995-8998. [CrossRef]

93. Plakas, S.M.; El Said, K.R.; Jester, E.L.E.; Granade, H.R.; Musser, S.M.; Dickey, R.W. Confirmation of brevetoxin metabolism in the Eastern oyster [Crassostrea virginica] by controlled exposures to pure toxins and to Karenia brevis cultures. Toxicon 2002, 40,721-729. [CrossRef]

94. Wang, Z.; Plakas, S.M.; El Said, K.R.; Jester, E.L.E.; Granade, H.R.; Dickey, R.W. LC/MS analysis of brevetoxin metabolites in the Eastern oyster [Crassostrea virginica]. Toxicon 2004, 43, 455-465. [CrossRef]

95. Baden, D.G. Brevetoxins: Unique polyether dinoflagellate toxins. FASEB J. 1989, 3, 1807-1817. [CrossRef] [PubMed]

96. Poli, M.A. Laboratory procedures for detoxification of equipment and waste contaminated with brevetoxins PbTx-2 and PbTx-3. J. Assoc. Off. Anal. Chem. 1988, 71, 1000-1002. [PubMed]

97. Baden, D.G.; Bourdelais, A.J.; Jacocks, H.; Michelliza, S.; Naar, J. Natural and derivative brevetoxins: Historical background, multiplicity, and effects. Environ. Health Perspect. 2005, 113, 621-625. [CrossRef] [PubMed]

98. U.S. FDA [United States Food and Drug Administration]. Fish and Fisheries Products Hazards and Controls Guidance, 3rd ed.; Appendix 5-FDA \& EPA Safety Levels in Regulations and Guidance; June 2001. Available online: http:/ / www.fda.gov / Food/GuidanceComplianceRegulatoryInformation/GuidanceDocuments / Seafood/ucm091782.htm (accessed on 24 July 2018 ).

99. FSANZ [Food Standards Australia New Zealand]. Food Standard Code, Incorporating Amendments up to and Including Amendment 116, Standard 4.1.1, Primary Production and Processing Standards, Preliminary provisisons, Standard 1.4.1, Contaminants and Natural toxicants, [Internet]. 2010. Available online: http://www.foodstandards.gov.au/_srcfiles/Standard_1_4_1_Contaminants_v113.pdf (accessed on 24 July 2018).

100. NZFSA (New Zealand Food). Animal products [specification for Bivalve Molluscan Shellfish]. 2006. Available online: http://www.nzfsa.govt.nz/animalproducts/legislation/notices/animal-materialproduct/shellfish/bmsrcsspecv-16_2_signed.pdf (accessed on 24 July 2018).

101. Miles, C.O.; Wilkins, A.L.; Munday, R.; Dines, M.H.; Hawkes, A.D.; Briggs, L.R.; Sandvik, M.; Jensen, D.J.; Cooney, J.M.; Holland, P.T.; et al. Isolation of pectenotoxin-2 from Dinophysis acuta and its conversion to pectenotoxin-2 seco acid, and preliminary assessment of their acute toxicities. Toxicon 2004, 43, 1-9. [CrossRef] [PubMed]

102. Miles, C.O. Pectenotoxins. In Phycotoxins Chemistry Biochemistry; Botana, L.B., Alfonso, A., Eds.; Wiley-Blackwell: Hoboken, NJ, USA, 2007; pp. 159-186.

103. Allingham, J.S.; Miles, C.O.; Rayment, I. A structural basis for regulation of actin polymerization by pectenotoxins. J. Mol. Biol. 2007, 371, 959-970. [CrossRef] [PubMed]

104. Sasaki, K.; Wright, J.L.C.; Yasumoto, T. Identification and characterization of pectenotoxin [PTX] 4 and PTX7 as spiroketal stereoisomers of two previously reported pectenotoxins. J. Org. Chem. 1998, 63, 2475-2480. [CrossRef] 
105. Suzuki, T.; Walter, J.A.; LeBlanc, P.; MacKinnon, S.; Miles, C.O.; Wilkins, A.L.; Munday, R.; Beuzenberg, V.; MacKenzie, A.L.; Jensen, D.J.; et al. Identification of pectenotoxin-11 as 34 S-hydroxypectenotoxin-2, a new pectenotoxin analogue in the toxic dinoflagellate Dinophysis acuta from New Zealand. Chem. Res. Toxicol. 2006, 19, 310-318. [CrossRef]

106. Zhou, Z.; Komiyama, M.; Terao, K.; Shimada, Y. Effects of pectenotoxin-1 on liver cells in vitro. Nat. Toxins 1994, 2, 132-135. [CrossRef]

107. Cañete, E.; Diogène, J. Comparative study of the use of neuroblastoma cells [Neuro-2a] and neuroblastoma $\times$ glioma hybrid cells [NG108-15] for the toxic effect quantification of marine toxins. Toxicon 2008, 52, 541-550. [CrossRef]

108. Toyofuku, H. Joint FAO/WHO/IOC activities to provide scientific advice on marine biotoxins. Mar. Pollut. Bull. 2006, 52, 1735-1745. [CrossRef]

109. Loader, J.I.; Hawkes, A.D.; Beuzenberg, V.; Jensen, D.J.; Cooney, J.M.; Wilkins, A.L.; Fitzgerald, J.M.; Briggs, L.R.; Miles, C.O. Convenient large-scale purification of yessotoxin from Protoceratium reticulatum culture and isolation of a novel furanoyessotoxin. J. Agric. Food Chem. 2007, 55, 11093-11100. [CrossRef] [PubMed]

110. Samdal, I.A. Yessotoxins in algae and mussels: Studies on its sources, disposition, and levels. uitgever niet vastgesteld. 2005. Available online: https://scholar.google.com.br/scholar?hl=pt-BR\&as_sdt=0\%2C5\& $\mathrm{q}=$ Yessotoxins+in+algae+and+mussels $\% 3 \mathrm{~A}+$ Studies+on+its+sources $\% 2 \mathrm{C}+$ disposition $\% 2 \mathrm{C}+$ and+levels. +uitgever+niet+vastgesteld\&btnG= (accessed on 10 June 2018).

111. EFSA. Opinion of the Scientific Panel on Contaminants in the Food chain on a request from the European Commission on marine biotoxins in shellfish-Yessotoxin group. EFSA J. 2008, 907, 1-62.

112. Alfonso, A.; de la Rosa, L.; Vieytes, M.R.; Yasumoto, T.; Botana, L.M. Yessotoxin, a novel phycotoxin, activates phosphodiesterase activity: Effect of yessotoxin on cAMP levels in human lymphocytes. Biochem. Pharmacol. 2003, 65, 193-208. [CrossRef]

113. Malagoli, D.; Casarini, L.; Ottaviani, E. Algal toxin yessotoxin signalling pathways involve immunocyte mussel calcium channels. Cell Biol. Int. 2006, 30, 721-726. [CrossRef] [PubMed]

114. Pierotti, S.; Malaguti, C.; Milandri, A.; Poletti, R.; Rossini, G.P. Functional assay to measure yessotoxins in contaminated mussel samples. Anal. Biochem. 2003, 312, 208-216. [CrossRef]

115. Malagoli, D.; Ottaviani, E. Yessotoxin affects fMLP-induced cell shape changes in Mytilus galloprovincialis immunocytes. Cell Biol. Int. 2004, 28, 57-61. [CrossRef] [PubMed]

116. Dell'Ovo, V.; Bandi, E.; Coslovich, T.; Florio, C.; Sciancalepore, M.; Decorti, G.; Sosa, S.; Lorenzon, P.; Yasumoto, T.; Tubaro, A. In vitro effects of yessotoxin on a primary culture of rat cardiomyocytes. Toxicol. Sci. 2008, 106, 392-399. [CrossRef]

117. Tillmann, U.; Elbrächter, M.; Krock, B.; John, U.; Cembella, A. Azadinium spinosum gen. et sp. nov. [Dinophyceae] identified as a primary producer of azaspiracid toxins. Eur.J. Phycol. 2009, 44, 63-79. [CrossRef]

118. James, K.J.; Moroney, C.; Roden, C.; Satake, M.; Yasumoto, T.; Lehane, M.; Furey, A. Ubiquitous 'benign'alga emerges as the cause of shellfish contamination responsible for the human toxic syndrome, azaspiracid poisoning. Toxicon 2003, 41, 145-151. [CrossRef]

119. Satake, M.; Ofuji, K.; Naoki, H.; James, K.J.; Furey, A.; McMahon, T.; Silke, J.; Yasumoto, T. Azaspiracid, a new marine toxin having unique spiro ring assemblies, isolated from Irish mussels, Mytilus edulis. J. Am. Chem. Soc. 1998, 120, 9967-9968. [CrossRef]

120. Ofuji, K.; Satake, M.; McMahon, T.; James, K.J.; Naoki, H.; Oshima, Y.; Yasumoto, T. Structures of azaspiracid analogs, azaspiracid-4 and azaspiracid-5, causative toxins of azaspiracid poisoning in Europe. Biosci. Biotechnol. Biochem. 2001, 65, 740-742. [CrossRef] [PubMed]

121. Ofuji, K.; Satake, M.; McMahon, T.; Silke, J.; James, K.J.; Naoki, H.; Oshima, Y.; Yasumoto, T. Two analogs of azaspiracid isolated from mussels, Mytilus edulis, involved in human intoxication in Ireland. Nat. Toxins 1999, 7, 99-102. [CrossRef]

122. Rehmann, N.; Hess, P.; Quilliam, M.A. Discovery of new analogs of the marine biotoxin azaspiracid in blue mussels [Mytilus edulis] by ultra-performance liquid chromatography/tandem mass spectrometry. Rapid Commun. Mass Spectrom. 2008, 22, 549-558. [CrossRef] [PubMed]

123. Brombacher, S.; Edmonds, S.; Volmer, D.A. Studies on azaspiracid biotoxins. II. Mass spectral behavior and structural elucidation of azaspiracid analogs. Rapid Commun mass Spectrom. 2002, 16, 2306-2316. [CrossRef] 
124. James, K.J.; Sierra, M.D.; Lehane, M.; Magdalena, A.B.; Furey, A. Detection of five new hydroxyl analogues of azaspiracids in shellfish using multiple tandem mass spectrometry. Toxicon 2003, 41, 277-283. [CrossRef]

125. Twiner, M.J.; Doucette, G.J.; Rasky, A.; Huang, X.-P.; Roth, B.L.; Sanguinetti, M.C. The marine algal toxin azaspiracid is an open state blocker of hERG potassium channels. Chem. Res. Toxicol. 2012, 25, 1975-1984. [CrossRef] [PubMed]

126. Bates, S.S.; Trainer, V.L. The ecology of harmful diatoms. In Ecology of Harmful Algae; Springer: New York, NY, USA, 2006; pp. 81-93.

127. Zaman, L.; Arakawa, O.; Shimosu, A.; Onoue, Y.; Nishio, S.; Shida, Y.; Noguchi, T. Two new isomers of domoic acid from a red alga, Chondria armata. Toxicon 1997, 35, 205-212. [CrossRef]

128. Walter, J.A.; Falk, M.; Wright, J.L.C. Chemistry of the shellfish toxin domoic acid: Characterization of related compounds. Can. J. Chem. 1994, 72, 430-436. [CrossRef]

129. Meda, M.; Kodama, T.; Tanaka, T.; Yoshizumi, H.; Takemoto, T.; Nomoto, K.; Fujita, T. Structures of isodomoic acids A, B and C, novel insecticidal amino acids from the red alga Chondria armata. Chem. Pharm. Bull. 1986, 34, 4892-4895. [CrossRef]

130. EFSA CONTAM Panel [EFSA Panel on Contaminants in the Food Chain]; Alexander, J.; Benford, D.; Cockburn, A.; Cravedi, J.P.; Dogliotti, E.; Di Domenico, A.; Fernández-Cruz, M.L.; Fink-Gremmels, J.; Galli, P.F.C.; et al. Scientific opinion of the panel on contaminants in the food chain on a request from the European commission on marine biotoxins in shellfish-Saxitoxin Group. EFSA J. 2009, 1019, 1-76.

131. Alexander, J.; Barregård, L.; Bignami, M.; Brüschweiler, B.; Ceccatelli, S.; Cottrill, B. Scientific opinion on the risks for public health related to the presence of tetrodotoxin [TTX] and TTX analogues in marine bivalves and gastropods. EFSA J. 2017, 15, 4752.

132. Vale, P. Metabolites of saxitoxin analogues in bivalves contaminated by Gymnodinium catenatum. Toxicon 2010, 55, 162-165. [CrossRef] [PubMed]

133. Oshima, Y. Postcolumn derivatization liquid chromatographic method for paralytic shellfish toxins. J. AOAC Int. 1995, 78, 528-532.

134. Vale, P. Complex profiles of hydrophobic paralytic shellfish poisoning compounds in Gymnodinium catenatum identified by liquid chromatography with fluorescence detection and mass spectrometry. J. Chromatogr. A 2008, 1195, 85-93. [CrossRef] [PubMed]

135. Negri, A.; Stirling, D.; Quilliam, M.; Blackburn, S.; Bolch, C.; Burton, I.; Eaglesham, G.; Thomas, K.; Walter, J.; Willis, R. Three novel hydroxybenzoate saxitoxin analogues isolated from the dinoflagellate Gymnodinium catenatum. Chem. Res. Toxicol. 2003, 16, 1029-1033. [CrossRef] [PubMed]

136. Mons, M.P.; Van Egmond, H.P.; Speijers, G.J.A. Paralytic shellfish poisoning: A review. J. Am. Vet. Med. Assoc. 1978, 171, 1178-1180.

137. Boczar, B.A.; Beitler, M.K.; Liston, J.; Sullivan, J.J.; Cattolico, R.A. Paralytic shellfish toxins in Protogonyaulax tamarensis and Protogonyaulax catenella in axenic culture. Plant Physiol. 1988, 88, 1285-1290. [CrossRef]

138. Cheng, C.A.; Hwang, D.F.; Tsai, Y.H.; Chen, H.C.; Jeng, S.S.; Noguchi, T.; Ohwada, K.; Hasimoto, K. Microflora and tetrodotoxin-producing bacteria in a gastropod, Niotha clathrata. Food Chem. Toxicol. 1995, 33, 929-934. [CrossRef]

139. Yu, C.-F.; Yu, P.H.-F.; Chan, P.-L.; Yan, Q.; Wong, P.-K. Two novel species of tetrodotoxin-producing bacteria isolated from toxic marine puffer fishes. Toxicon 2004, 44, 641-647. [CrossRef]

140. Yotsu, M.; Yamazaki, T.; Meguro, Y.; Endo, A.; Murata, M.; Naoki, H.; Yasumoto, T. Production of tetrodotoxin and its derivatives by Pseudomonas sp. isolated from the skin of a pufferfish. Toxicon 1987, 25, 225-228. [CrossRef]

141. Auawithoothij, W.; Noomhorm, A. Shewanella putrefaciens, a major microbial species related to tetrodotoxin [TTX]-accumulation of puffer fish Lagocephalus lunaris. J. Appl. Microbiol. 2012, 113, 459-465. [CrossRef] [PubMed]

142. Hwang, D.F.; Arakawa, O.; Saito, T.; Noguchi, T.; Simidu, U.; Tsukamoto, K.; Shida, Y.; Hashimoto, K. Tetrodotoxin-producing bacteria from the blue-ringed octopus Octopus maculosus. Mar. Biol. 1989, 100, 327-332. [CrossRef]

143. Ritchie, K.B.; Nagelkerken, I.; James, S.; Smith, G.W. Environmental microbiology: A tetrodotoxin-producing marine pathogen. Nature 2000, 404, 354. [CrossRef] [PubMed] 
144. Wu, Z.; Xie, L.; Xia, G.; Zhang, J.; Nie, Y.; Hu, J.; Wang, S.; Zhang, R. A new tetrodotoxin-producing actinomycete, Nocardiopsis dassonvillei, isolated from the ovaries of puffer fish Fugu rubripes. Toxicon 2005, 45, 851-859. [CrossRef] [PubMed]

145. Bane, V.; Lehane, M.; Dikshit, M.; O’Riordan, A.; Furey, A. Tetrodotoxin: Chemistry, toxicity, source, distribution and detection. Toxins 2014, 6, 693-755. [CrossRef] [PubMed]

146. Noguch, T.; Arakawa, O. Tetrodotoxin-distribution and accumulation in aquatic organisms, and cases of human intoxication. Mar. Drugs 2008, 6, 220-242. [CrossRef]

147. Vasconcelos, V.; Azevedo, J.; Silva, M.; Ramos, V. Effects of marine toxins on the reproduction and early stages development of aquatic organisms. Mar. Drugs 2010, 8, 59-79. [CrossRef]

148. White, J.; Meier, J. Handbook of Clinical Toxicology of Animal Venoms And Poisons; CRC Press: Boca Raton, FL, USA, 2017.

149. Jang, J.-H.; Lee, J.-S.; Yotsu-Yamashita, M. LC/MS analysis of tetrodotoxin and its deoxy analogs in the marine puffer fish Fugu niphobles from the southern coast of Korea, and in the brackishwater puffer fishes Tetraodon nigroviridis and Tetraodon biocellatus from Southeast Asia. Mar. Drugs 2010, 8, 1049-1058. [CrossRef]

150. Jang, J.; Yotsu-Yamashita, M. Distribution of tetrodotoxin, saxitoxin, and their analogs among tissues of the puffer fish Fugu pardalis. Toxicon 2006, 48, 980-987. [CrossRef]

151. Kudo, Y.; Finn, J.; Fukushima, K.; Sakugawa, S.; Cho, Y.; Konoki, K.; Yotsu-Yamashita, M. Isolation of 6-deoxytetrodotoxin from the pufferfish, Takifugu pardalis, and a comparison of the effects of the C-6 and C-11 hydroxy groups of tetrodotoxin on its activity. J. Nat. Prod. 2014, 77, 1000-1004. [CrossRef]

152. Yotsu-Yamashita, M.; Abe, Y.; Kudo, Y.; Ritson-Williams, R.; Paul, V.J.; Konoki, K.; Cho, Y.; Adachi, M.; Imazu, T.; Nishikawa, T.; et al. First identification of 5, 11-dideoxytetrodotoxin in marine animals, and characterization of major fragment ions of tetrodotoxin and its analogs by high resolution ESI-MS/MS. Mar. Drugs 2013, 11, 2799-2813. [CrossRef] [PubMed]

153. Moore, R.E.; Bartolini, G. Structure of palytoxin. J. Am. Chem. Soc. 1981, 103, 2491-2494. [CrossRef]

154. Ramos, V.; Vasconcelos, V. Palytoxin and analogs: Biological and ecological effects. Mar. Drugs 2010, 8 , 2021-2037. [CrossRef] [PubMed]

155. Ukena, T.; Satake, M.; Usami, M.; Oshimay, Y.; Naoki, H.; Fujita, T.; Kan, Y.; Yasumoto, T. Structure elucidation of ostreocin D, a palytoxin analog isolated from the dinoflagellate Ostreopsis siamensis. Biosci. Biotechnol. Biochem. 2001, 65, 2585-2588. [CrossRef] [PubMed]

156. Kerbrat, A.S.; Amzil, Z.; Pawlowiez, R.; Golubic, S.; Sibat, M.; Darius, H.T.; Chinain, M.; Laurent, D. First evidence of palytoxin and 42-hydroxy-palytoxin in the marine cyanobacterium Trichodesmium. Mar. Drugs 2011, 9, 543-560. [CrossRef] [PubMed]

157. Alexander, J.; Benford, D.; Boobis, A.; Ceccatelli, S.; Cravedi, J.P.; Di Domenico, A.; Doerge, D.; Dogliotti, E.; Edler, L.; Farmer, P.; et al. EFSA Panel on Contaminants in the Food Chain [CONTAM]; Scientific Opinion on marine biotoxins in shellfish-Palytoxin group. EFSA J. 2009, 7, 1393.

158. Botana, L.M. Seafood and Freshwater Toxins: Pharmacology, Physiology, and Detection; CRC Press: Boca Raton, FL, USA, 2014.

159. García-Altares, M.; Tartaglione, L.; Dell'Aversano, C.; Carnicer, O.; de la Iglesia, P.; Forino, M.; Diogène, J.; Ciminiello, P. The novel ovatoxin-g and isobaric palytoxin [so far referred to as putative palytoxin] from Ostreopsis cf. ovata [NW Mediterranean Sea]: Structural insights by LC-high resolution MSn. Anal. Bioanal. Chem. 2015, 407, 1191-1204. [CrossRef]

160. Lenoir, S.; Ten-Hage, L.; Turquet, J.; Quod, J.P.; Hennion, M.C. Characterisation of new analogues of palytoxin isolated from an Ostreopsis mascarenensis bloom in the south-western Indian Ocean. Afr. J. Mar. Sci. 2006, 28, 389-391. [CrossRef]

161. Habermann, E.; Chhatwal, G.S. Ouabain inhibits the increase due to palytoxin of cation permeability of erythrocytes. Naunyn-Schmiedeberg Arch. Pharmacol. 1982, 319, 101-107. [CrossRef]

162. Miller, M.A.; Kudela, R.M.; Mekebri, A.; Crane, D.; Oates, S.C.; Tinker, M.T.; Staedler, M.; Miller, W.A.; Toy-Choutka, S.; Dominik, C.; et al. Evidence for a novel marine harmful algal bloom: Cyanotoxin [microcystin] transfer from land to sea otters. PLoS ONE 2010, 5, e12576. [CrossRef]

163. Chorus, I.; Bartram, J. Toxic Cyanobacteria in Water: A Guide to Their Public Health Consequences, Monitoring and Management; CRC Press: Boca Raton, FL, USA, 1999. 
164. Gantar, M.; Sekar, R.; Richardson, L.L. Cyanotoxins from black band disease of corals and from other coral reef environments. Microb. Ecol. 2009, 58, 856-864. [CrossRef] [PubMed]

165. Stanić, D.; Oehrle, S.; Gantar, M.; Richardson, L.L. Microcystin production and ecological physiology of Caribbean black band disease cyanobacteria. Environ. Microbiol. 2011, 13, 900-910. [CrossRef] [PubMed]

166. Ramos, A.G.; Martel, A.; Codd, G.A.; Soler, E.; Coca, J.; Redondo, A.; Morrison, L.F.; Metcalf, J.S.; Ojeda, A.; Suárez, S.; et al. Bloom of the marine diazotrophic cyanobacterium Trichodesmium erythraeum in the Northwest African Upwelling. Mar. Ecol. Prog. Ser. 2005, 301, 303-305. [CrossRef]

167. Vareli, K.; Zarali, E.; Zacharioudakis, G.S.A.; Vagenas, G.; Varelis, V.; Pilidis, G.; Briasoulis, E.; Sainisf, F. Microcystin producing cyanobacterial communities in Amvrakikos Gulf [Mediterranean Sea, NW Greece] and toxin accumulation in mussels [Mytilus galloprovincialis]. Harmful Algae 2012, 15, 109-118. [CrossRef]

168. Frazão, B.; Martins, R.; Vasconcelos, V. Are known cyanotoxins involved in the toxicity of picoplanktonic and filamentous North Atlantic marine cyanobacteria? Mar. Drugs 2010, 8, 1908-1919. [CrossRef] [PubMed]

169. Proença, L.A.O.; Tamanaha, M.S.; Fonseca, R.S. Screening the toxicity and toxin content of blooms of the cyanobacterium Trichodesmium erythraeum [Ehrenberg] in northeast Brasil. J. Venom. Anim. Toxins Incl. Trop. Dis. 2009, 15, 204-215. [CrossRef]

170. Charpy, L.; Palinska, K.A.; Casareto, B.; Langlade, M.J.; Suzuki, Y.; Abed, R.M.M.; Golubic, S. Dinitrogen-fixing cyanobacteria in microbial mats of two shallow coral reef ecosystems. Microb. Ecol. 2010, 59, 174-186. [CrossRef]

171. Osborne, N.J.T.; Webb, P.M.; Shaw, G.R. The toxins of Lyngbya majuscula and their human and ecological health effects. Environ. Int. 2001, 27, 381-392. [CrossRef]

172. Nagai, H.; Yasumoto, T.; Hokama, Y. Aplysiatoxin and debromoaplysiatoxin as the causative agents of a red alga Gracilaria coronopifolia poisoning in Hawaii. Toxicon 1996, 34, 753-761. [CrossRef]

173. Wu, M.; Okino, T.; Nogle, L.M.; Marquez, B.L.; Williamson, R.T.; Sitachitta, N.; Berman, F.W.; Murray, T.F.; McGough, K.; Jacobs, R.; et al. Structure, Synthesis, and Biological Properties of Kalkitoxin, a Novel Neurotoxin from the Marine Cyanobacterium Lyngbya majuscula. J. Am. Chem. Soc. 2000, 122, 12041-12042. [CrossRef]

174. Fujiki, H.; Mori, M.; Nakayasu, M.; Terada, M.; Sugimura, T.; Moore, R.E. Indole alkaloids: Dihydroteleocidin B, teleocidin, and lyngbyatoxin A as members of a new class of tumor promoters. Proc. Natl. Acad. Sci. USA 1981, 78, 3872-3876. [CrossRef]

175. Wood, S.A.; Stirling, D.J. First identification of the cylindrospermopsin-producing cyanobacterium Cylindrospermopsis raciborskii in New Zealand. N. Z. J. Mar. Freshw. Res. 2003, 37, 821-828. [CrossRef]

176. Edwards, D.J.; Gerwick, W.H. Lyngbyatoxin biosynthesis: Sequence of biosynthetic gene cluster and identification of a novel aromatic prenyltransferase. J. Am. Chem. Soc. 2004, 126, 11432-11433. [CrossRef] [PubMed]

177. Méjean, A.; Peyraud-Thomas, C.; Kerbrat, A.S.; Golubic, S.; Pauillac, S.; Chinain, M.; Laurent, D. First identification of the neurotoxin homoanatoxin-a from mats of Hydrocoleum lyngbyaceum [marine cyanobacterium] possibly linked to giant clam poisoning in New Caledonia. Toxicon 2010, 56, 829-835. [CrossRef] [PubMed]

178. Roué, M.; Gugger, M.; Golubic, S.; Amzil, Z.; Araoz, R.; Turquet, J.; Chinain, M.; Laurent, D. Marine cyanotoxins potentially harmful to human health. Outst. Mar. Mol. Chem. Biol. Anal. 2014, 1-22. [CrossRef]

179. Orjala, J.; Nagle, D.G.; Hsu, V.; Gerwick, W.H. Antillatoxin: An exceptionally ichthyotoxic cyclic lipopeptide from the tropical cyanobacterium Lyngbya majuscula. J. Am. Chem. Soc. 1995, 117, 8281-8282. [CrossRef]

180. Fernández, M.L.; Míguez, A.; Cacho, E.; Martínez, A.; Diogéne, J.; Yasumoto, T. Bioensayos con mamíferos y ensayos bioquímicos y celulares para la detección de ficotoxinas. Floraciones algales nocivas en el Cono Sur Am. 2002, 77-120.

181. Kat, M. Diarrhetic mussel poisoning in the Netherlands related to the dinoflagellate Dinophysis acuminata. Antonie Van Leeuwenhoek 1983, 49, 417-427.

182. Regulation, E.C. No 854/2004 OF THE EUROPEAN PARLIAMENT AND OF THE COUNCIL of 29 April 2004 laying down specific rules for the organisation of official controls on products of animal origin intended for human consumption. Off. J. Eur. Union L. 2012, 155, 206.

183. EFSA CONTAM Panel [EFSA Panel on Contaminants in the Food Chain]; Alexander, J.; Auðunsson, A.G.; Benford, D.C.A.; Cravedi, J.P.; Dogliotti, E.; Domenico, A.D.F.-C.M.; Fink-Gremmels, J.; Fürst, J.; Galli, C.; et al. 2017. Marine biotoxins in shellfish-okadaic acid and analogues. EFSA J. 2008, 589, 1-62. 
184. Kleivdal, H.; Kristiansen, S.-I.; Nilsen, M.V.; Goksyr, A.; Briggs, L.; Holland, P.; McNabb, P. Determination of Domoic Acid Toxins in Shellfish by Biosense ASP ELISAA Direct Competitive Enzyme-Linked Immunosorbent Assay: Collaborative Study. J. AOAC Int. 2007, 90, 1011-1027. [PubMed]

185. Simon, J.F.; Vemoux, J. Highly sensitive assay of okadaic acid using protein phosphatase and paranitrophenyl phosphate. Nat. Toxins 1994, 2, 293-301. [CrossRef] [PubMed]

186. Vieytes, M.R.; Fontal, O.I.; Leira, F.; de Sousa, J.M.V.B.; Botana, L.M. A fluorescent microplate assay for diarrheic shellfish toxins. Anal. Biochem. 1997, 248, 258-264. [CrossRef]

187. Lee, J.S.; Yanagi, T.; Kenma, R.; Yasumoto, T. Fluorometric determination of diarrhetic shellfish toxins by high-performance liquid chromatography. Agric. Biol. Chem. 1987, 51, 877-881.

188. Darius, H.T.; Ponton, D.; Revel, T.; Cruchet, P.; Ung, A.; Fouc, M.T.; Chinain, M. Ciguatera risk assessment in two toxic sites of French Polynesia using the receptor-binding assay. Toxicon 2007, 50, 612-626. [CrossRef] [PubMed]

189. Banner, A.H.; Scheuer, P.J.; Sasaki, S.; Helfrich, P.; Alender, C.B. Observations on ciguatera-type toxin in fish. Ann. N. Y. Acad. Sci. 1960, 90, 770-787. [CrossRef] [PubMed]

190. Lewis, R.J.; Sellin, M. Recovery of ciguatoxin from fish flesh. Toxicon 1993, 31, 1333-1336. [CrossRef]

191. CDC [Centers for Disease Control and Prevention]. Cluster of ciguatera fish poisoning-North Carolina, 2007. Morbidity and Mortality Weekly Report [MMWR] [Internet]. North Carolina. 2009. Available online: http:/ / www.cdc.gov/mmwr/PDF/wk/mm5811.pdf (accessed on 20 July 2018).

192. Manger, R.L.; Leja, L.S.; Lee, S.Y.; Hungerford, J.M.; Wekell, M.M. Tetrazolium-based cell bioassay for neurotoxins active on voltage-sensitive sodium channels: Semiautomated assay for saxitoxins, brevetoxins, and ciguatoxins. Anal. Biochem. 1993, 214, 190-194. [CrossRef]

193. Manger, R.L.; Leja, L.S.; Lee, S.Y.; Hungerford, J.M.; Wekell, M.M. Cell bioassay for the detection of ciguatoxins, brevetoxins, and saxitoxins. Mem. Queensl. Museum. Brisb. 1994, 34, 571-575.

194. Manger, R.L.; Leja, L.S.; Lee, S.Y.; Hungerford, J.M.; Hokama, Y.; Dickey, R.W.; Granade, H.R.; Lewis, R.; Yasumoto, T.; Wekell, M.M. Detection of sodium channel toxins: Directed cytotoxicity assays of purified ciguatoxins, brevetoxins, saxitoxins, and seafood extracts. J. AOAC Int. 1995, 78, 521-527.

195. Empey Campora, C.; Hokama, Y.; Yabusaki, K.; Isobe, M. Development of an enzyme-linked immunosorbent assay for the detection of ciguatoxin in fish tissue using chicken immunoglobulin Y. J. Clin. Lab. Anal. 2008, 22, 239-245. [CrossRef] [PubMed]

196. Hokama, Y.; Banner, A.H.; Boylan, D.B. A radioimmunoassay for the detection of ciguatoxin. Toxicon 1977, 15, 317-325. [CrossRef]

197. Hokama, Y.; Honda, S.A.A.; Uyehara, K.; Shirai, L.K.; Kobayashi, M.N. Monoclonal-antibodies to low dalton natural marine toxins. J. Toxicol. Rev. 1986, 5, 194.

198. Hokama, Y.; Kimura, L.H.; Abad, M.A.; Yokochi, L.; Scheuer, P.J.; Nukina, M.; Yasumoto, T.; Baden, D.G.; Shimizu, Y. An Enzyme Immunoassay for the Detection of Ciguatoxin: And Competitive Inhibition by Related Natural Polyether Toxins; ACS Publications: Washington, DC, USA, 1984; pp. 1947-5918.

199. Hokama, Y.; Shirai, L.K.; Iwamoto, L.M.; Kobayashi, M.N.; Goto, C.S.; Nakagawa, L.K. Assessment of a rapid enzyme immunoassay stick test for the detection of ciguatoxin and related polyether toxins in fish tissues. Biol. Bull. 1987, 172, 144-153. [CrossRef]

200. Lewis, R.J.; Jones, A.; Vernoux, J.-P. HPLC/tandem electrospray mass spectrometry for the determination of sub-ppb levels of Pacific and Caribbean ciguatoxins in crude extracts of fish. Anal. Chem. 1999, 71, 247-250. [CrossRef] [PubMed]

201. Dickey, R.W.; Bencsath, F.A.; Granade, H.R.; Lewis, R.J. Liquid chromatographic mass spectrometric methods for the determination of marine polyether toxins. Bull. Soc. Pathol. Exot. 1992, 85 Pt 2, 514-515.

202. Yasumoto, T.; Fukui, M.; Sasaki, K.; Sugiyama, K. Determinations of marine toxins in foods. J. AOAC Int. 1995, 78, 574-582.

203. Vilariño, N.; Fonfría, E.S.; Molgó, J.; Aráoz, R.; Botana, L.M. Detection of gymnodimine-A and 13-desmethyl C spirolide phycotoxins by fluorescence polarization. Anal. Chem. 2009, 81, 2708-2714. [CrossRef]

204. Ciminiello, P.; Dell'Aversano, C.; Fattorusso, E.; Forino, M.; Magno, G.S.; Tartaglione, L.; Grillo, C.; Melchiorre, N. The Genoa 2005 Outbreak. Determination of Putative Palytoxin in Mediterranean Ostreopsis o vata by a New Liquid Chromatography Tandem Mass Spectrometry Method. Anal. Chem. 2006, 78, 6153-6159. [CrossRef] 
205. Marrouchi, R.; Dziri, F.; Belayouni, N.; Hamza, A.; Benoit, E.; Molgó, J.; Kharrat, R. Quantitative determination of gymnodimine-A by high performance liquid chromatography in contaminated clams from Tunisia coastline. Mar. Biotechnol. 2010, 12, 579-585. [CrossRef]

206. Association, A.P.H. Recommended procedures for the examination of sea water and shellfish. In Recommended Procedures for the Examination of Sea Water and Shellfish; APHA: Cincinnati, OH, USA, 1970.

207. Briggs, L.R.; Garthwaite, L.L.; Miles, C.O.; Garthwaite, I.; Ross, K.M.; Towers, N.R. The newest ELISA_Pectenotoxin. In Marine Biotoxin Science Workshop; Marine Institute: Galway, Ireland, 2000; pp. 71-75.

208. Naar, J.; Bourdelais, A.; Tomas, C.; Kubanek, J.; Whitney, P.L.; Flewelling, L.; Steidinger, K.; Lancaster, J.; Baden, D.G. A competitive ELISA to detect brevetoxins from Karenia brevis [formerly Gymnodinium breve] in seawater, shellfish, and mammalian body fluid. Environ. Health Perspect. 2002, 110, 179-185. [CrossRef] [PubMed]

209. Wang, W.; Cole, R.B. Enhanced collision-induced decomposition efficiency and unraveling of fragmentation pathways for anionic adducts of brevetoxins in negative ion electrospray mass spectrometry. Anal. Chem. 2009, 81, 8826-8838. [CrossRef] [PubMed]

210. Regulation, E.U. 853/2004. Regulation [EC] no. 853/2004 of the European Parliament and of the Council of 29 April 2004. Laying down specific hygiene rules for food of animal origin. Off. J. Eur. Union 2004, 226, $22-82$.

211. McNabb, P.; Selwood, A.I.; Holland, P.T. Multiresidue method for determination of algal toxins in shellfish: Single-laboratory validation and interlaboratory study. J. AOAC Int. 2005, 88, 761-772. [PubMed]

212. Stobo, L.A.; Lacaze, J.-P.C.L.; Scott, A.C.; Gallacher, S.; Smith, E.A.; Quilliam, M.A. Liquid chromatography with mass spectrometry-detection of lipophilic shellfish toxins. J. AOAC Int. 2005, 88, 1371-1382. [PubMed]

213. Briggs, L.R.; Miles, C.O.; Fitzgerald, J.M.; Ross, K.M.; Garthwaite, I.; Towers, N.R. Enzyme-linked immunosorbent assay for the detection of yessotoxin and its analogues. J. Agric. Food Chem. 2004, 52, 5836-5842. [CrossRef]

214. Satake, M.; Ofuji, K.; James, K.J.; Furey, A.; Yasumoto, T. New toxic event caused by Irish mussels. Harmful Algae 1998, 468-469.

215. [EFSA] EFSA. Marine biotoxins in shellfish-saxitoxin group. EFSA J. 2009, 7, 1019. [CrossRef]

216. Krock, B.; Pitcher, G.C.; Ntuli, J.; Cembella, A.D. Confirmed identification of gymnodimine in oysters from the west coast of South Africa by liquid chromatography-tandem mass spectrometry. Afr. J. Mar. Sci. 2009, 31, 113-118. [CrossRef]

217. Sommer, H.; Meyer, K.F. Paralytic Shell-Fish Poisoning. Arch. Pathol. 1937, 24, 560-598.

218. Catterall, W.A.; Morrow, C.S. Binding to saxitoxin to electrically excitable neuroblastoma cells. Proc. Natl. Acad. Sci. USA 1978, 75, 218-222. [CrossRef] [PubMed]

219. Jellett, J.F.; Marks, L.J.; Stewart, J.E.; Dorey, M.L.; Watson-Wright, W.; Lawrence, J.F. Paralytic shellfish poison [saxitoxin family] bioassays: Automated endpoint determination and standardization of the in vitro tissue culture bioassay, and comparison with the standard mouse bioassay. Toxicon 1992, 30, 1143-1156. [CrossRef]

220. Campbell, K.; Stewart, L.D.; Doucette, G.J.; Fodey, T.L.; Haughey, S.A.; Vilariño, N.; Kawatsu, K.; Elliott, C.T. Assessment of specific binding proteins suitable for the detection of paralytic shellfish poisons using optical biosensor technology. Anal. Chem. 2007, 79, 5906-5914. [CrossRef] [PubMed]

221. Carlson, R.E.; Lever, M.L.; Lee, B.W.; Guire, P.E. Development of Immunoassays for Paralytic Shellfish Poisoning: A Radioimmunoassay for Saxitoxin; ACS Publications: New York, NY, USA, 1984.

222. Fonfría, E.S.; Vilariño, N.; Campbell, K.; Elliott, C.; Haughey, S.A.; Ben-Gigirey, B.; Vieites, J.M.; Kawatsu, K.; Botana, L.M. Paralytic shellfish poisoning detection by surface plasmon resonance-based biosensors in shellfish matrixes. Anal. Chem. 2007, 79, 6303-6311. [CrossRef] [PubMed]

223. Jellett, J.F.; Roberts, R.L.; Laycock, M.V.; Quilliam, M.A.; Barrett, R.E. Detection of paralytic shellfish poisoning [PSP] toxins in shellfish tissue using MIST Alert ${ }^{\mathrm{TM}}$, a new rapid test, in parallel with the regulatory AOAC ${ }^{\circledR}$ mouse bioassay. Toxicon 2002, 40, 1407-1425. [CrossRef]

224. Usleber, E.; Schneider, E.; Terplan, G.; Laycock, M.V. Two formats of enzyme immunoassay for the detection of saxitoxin and other paralytic shellfish poisoning toxins. Food Addit. Contam. 1995, 12, 405-413. [CrossRef] [PubMed]

225. Thibault, P.; Pleasance, S.; Laycock, M.V. Analysis of paralytic shellfish poisons by capillary electrophoresis. J. Chromatogr. A 1991, 542, 483-501. [CrossRef] 
226. Dell'Aversano, C.; Hess, P.; Quilliam, M.A. Hydrophilic interaction liquid chromatography-mass spectrometry for the analysis of paralytic shellfish poisoning [PSP] toxins. J. Chromatogr. A 2005, 1081, 190-201. [CrossRef]

227. Franco, J.M.; Fernández-Vila, P. Separation of paralytic shellfish toxins by reversed phase high performance liquid chromatography, with postcolumn reaction and fluorimetric detection. Chromatographia 1993, 35, 613-620. [CrossRef]

228. Lawrence, J.F.; Menard, C. Liquid chromatographic determination of paralytic shellfish poisons in shellfish after prechromatographic oxidation. J. Assoc. Off. Anal. Chem. 1991, 74, 1006-1012.

229. Silva, M.; Rey, V.; Botana, A.; Vasconcelos, V.; Botana, L. Determination of Gonyautoxin-4 in Echinoderms and Gastropod Matrices by Conversion to Neosaxitoxin Using 2-Mercaptoethanol and Post-Column Oxidation Liquid Chromatography with Fluorescence Detection. Toxins 2015, 8, 11. [CrossRef] [PubMed]

230. Panel, E.C. Scienti fi c opinion on marine biotoxins in shell fi sh-domoic acid. EFSA panel Contam food Chain [CONTAM]. EFSA J. 2009, 1181, 1-61.

231. Garthwaite, I.; Ross, K.M.; Miles, C.O.; Hansen, R.P.; Foster, D.; Wilkins, A.L.; Wilkins, A.L.; Towers, N.R. Polyclonal antibodies to domoic acid, and their use in immunoassays for domoic acid in sea water and shellfish. Nat. Toxins 1998, 6, 93-104. [CrossRef]

232. Traynor, I.M.; Plumpton, L.; Fodey, T.L.; Higgins, C.; Elliott, C.T. Immunobiosensor detection of domoic acid as a screening test in bivalve molluscs: Comparison with liquid chromatography-based analysis. J. AOAC Int. 2006, 89, 868-872. [PubMed]

233. Quilliam, M.A.; Xie, M.; Hardstaff, W.R. Rapid extraction and cleanup for liquid chromatographic determination of domoic acid in unsalted seafood. J. AOAC Int. 1995, 78, 543-554.

234. Pocklington, R.; Milley, J.E.; Bates, S.S.; Bird, C.J.; De Freitas, A.S.W.; Quilliam, M.A. Trace determination of domoic acid in sea water and phytoplankton by high-performance liquid chromatography of the fluorenylmethoxycarbonyl [FMOC] derivative. Int. J. Environ. Anal. Chem. 1990, 38, 351-368. [CrossRef]

235. Van Dolah, F.M.; Leighfield, T.A.; Haynes, B.L.; Hampson, D.R.; Ramsdell, J.S. A microplate receptor assay for the amnesic shellfish poisoning toxin, domoic acid, utilizing a cloned glutamate receptor. Anal. Biochem. 1997, 245, 102-105. [CrossRef]

236. Zhao, J.; Thibault, P.; Quilliam, M.A. Analysis of domoic acid isomers in seafood by capillary electrophoresis. Electrophoresis 1997, 18, 268-276. [CrossRef]

237. Pineiro, N.; Leao, J.M.; Martınez, A.G.; Vázquez, J.A.R. Capillary electrophoresis with diode array detection as an alternative analytical method for paralytic and amnesic shellfish toxins. J. Chromatogr. A 1999, 847, 223-232. [CrossRef]

238. Nguyen, A.-L.; Luong, J.H.T.; Masson, C. Capillary electrophoresis for detection and quantitation of domoic acid in mussels. Anal. Lett. 1990, 23, 1621-1634. [CrossRef]

239. Wright, J.L.C.; Boyd, R.K.; de Freitas, A.S.W.; Falk, M.; Foxall, R.A.; Jamieson, W.D.; Laycock, M.V.; McCulloch, A.W.; McInnes, A.G.; Odense, P.; et al. Identification of domoic acid, a neuroexcitatory amino acid, in toxic mussels from eastern Prince Edward Island. Can. J. Chem. 1989, 67, 481-490. [CrossRef]

240. Pardo, O.; Yusà, V.; León, N.; Pastor, A. Development of a pressurised liquid extraction and liquid chromatography with electrospray ionization-tandem mass spectrometry method for the determination of domoic acid in shellfish. J. Chromatogr. A 2007, 1154, 287-294. [CrossRef]

241. Lawrence, J.F.; Charbonneau, C.F.; Ménard, C. Liquid chromatographic determination of domoic acid in mussels, using AOAC paralytic shellfish poison extraction procedure: Collaborative study. J. Assoc. Off. Anal. Chem. 1991, 74, 68-72. [PubMed]

242. Quilliam, M.A.; Sim, P.G.; McCulloch, A.W.; McInnes, A.G. High-performance liquid chromatography of domoic acid, a marine neurotoxin, with application to shellfish and plankton. Int. J. Environ. Anal. Chem. 1989, 36, 139-154. [CrossRef]

243. Quilliam, M.A.; Thomas, K.; Wright, J.L.C. Analysis of domoic acid in shellfish by thin-layer chromatography. Nat. Toxins 1998, 6, 147-152. [CrossRef]

244. Noguchi, T.; Ebesu, J.S.M. Puffer poisoning: Epidemiology and treatment. J. Toxicol. Toxin Rev. 2001, $20,1-10$. [CrossRef]

245. Yang, G.; Xu, J.; Liang, S.; Ren, D.; Yan, X.; Bao, B. A novel TTX-producing Aeromonas isolated from the ovary of Takifugu obscurus. Toxicon 2010, 56, 324-329. [CrossRef] 
246. Chulanetra, M.; Sookrung, N.; Srimanote, P.; Indrawattana, N.; Thanongsaksrikul, J.; Sakolvaree, Y.; Chongsa-Nguan, M.; Kurazono, H.; Chaicumpa, W. Toxic marine puffer fish in Thailand seas and tetrodotoxin they contained. Toxins 2011, 3, 1249-1262. [CrossRef]

247. Katikou, P.; Georgantelis, D.; Sinouris, N.; Petsi, A.; Fotaras, T. First report on toxicity assessment of the Lessepsian migrant pufferfish Lagocephalus sceleratus [Gmelin, 1789] from European waters [Aegean Sea, Greece]. Toxicon 2009, 54, 50-55. [CrossRef]

248. Hungerford, J.M. Committee on natural toxins and food allergens: Marine and freshwater toxins. J. AOAC Int. 2006, 89, 248-269.

249. Doucette, G.J.; Powell, C.L.; Do, E.U.; Byon, C.Y.; Cleves, F.; McClain, S.G. Evaluation of 11-[3H]-tetrodotoxin use in a heterologous receptor binding assay for PSP toxins. Toxicon 2000, 38, 1465-1474. [CrossRef]

250. Mahmud, Y.; Arakawa, O.; Ichinose, A.; Tanu, M.B.; Takatani, T.; Tsuruda, K.; Kawatsu, K.; Hamano, Y.; Noguchi, T. Intracellular visualization of tetrodotoxin [TTX] in the skin of a puffer Tetraodon nigroviridis by immunoenzymatic technique. Toxicon 2003, 41, 605-611. [CrossRef]

251. Mahmud, Y.; Okada, K.; Takatani, T.; Kawatsu, K.; Hamano, Y.; Arakawa, O.; Noguchi, T. Intra-tissue distribution of tetrodotoxin in two marine puffers Takifugu vermicularis and Chelonodon patoca. Toxicon 2003, 41, 13-18. [CrossRef]

252. Tsuruda, K.; Arakawa, O.; Kawatsu, K.; Hamano, Y.; Takatani, T.; Noguchi, T. Secretory glands of tetrodotoxin in the skin of the Japanese newt Cynops pyrrhogaster. Toxicon 2002, 40, 131-136. [CrossRef]

253. Brillantes, S.; Samosorn, W.; Faknoi, S.; Oshima, Y. Toxicity of puffers landed and marketed in Thailand. Fish. Sci. 2003, 69, 1224-1230. [CrossRef]

254. Bignami, G.S.; Raybould, T.J.G.; Sachinvala, N.D.; Grothaus, P.G.; Simpson, S.B.; Lazo, C.B.; Byrnes, J.B.; Moore, R.E.; Vann, D.C. Monoclonal antibody-based enzyme-linked immunoassays for the measurement of palytoxin in biological samples. Toxicon 1992, 30, 687-700. [CrossRef]

255. Kawatsu, K.; Shibata, T.; Hamano, Y. Application of immunoaffinity chromatography for detection of tetrodotoxin from urine samples of poisoned patients. Toxicon 1999, 37, 325-333. [CrossRef]

256. Tanu, M.B.; Mahmud, Y.; Takatani, T.; Kawatsu, K.; Hamano, Y.; Arakawa, O.; Noguchi, T. Localization of tetrodotoxin in the skin of a brackishwater puffer Tetraodon steindachneri on the basis of immunohistological study. Toxicon 2002, 40, 103-106. [CrossRef]

257. Nagashima, Y.; Nishio, S.; Noguchi, T.; Arakawa, O.; Kanoh, S.; Hashimoto, K. Detection of tetrodotoxin by thin-layer chromatography/fast atom bombardment mass spectrometry. Anal. Biochem. 1988, 175, 258-262. [CrossRef]

258. Man, C.N.; Noor, N.M.; Harn, G.L.; Lajis, R.; Mohamad, S. Screening of tetrodotoxin in puffers using gas chromatography-mass spectrometry. J. Chromatogr. A 2010, 1217, 7455-7459. [CrossRef]

259. Shiu, Y.-C.; Lu, Y.-H.; Tsai, Y.-H.; Chen, S.-K.; Hwang, D.-F. Occurrence of tetrodotoxin in the causative gastropod Polinices didyma and another gastropod Natica lineata collected from western Taiwan. J. Food Drug Anal. 2003, 11, 159-163.

260. Chen, X.-W.; Liu, H.-X.; Jin, Y.-B.; Li, S.-F.; Bi, X.; Chung, S.; Zhang, S.S.; Jiang, Y.Y. Separation, identification and quantification of tetrodotoxin and its analogs by LC-MS without calibration of individual analogs. Toxicon 2011, 57, 938-943. [CrossRef]

261. Diener, M.; Christian, B.; Ahmed, M.S.; Luckas, B. Determination of tetrodotoxin and its analogs in the puffer fish Takifugu oblongus from Bangladesh by hydrophilic interaction chromatography and mass-spectrometric detection. Anal. Bioanal. Chem. 2007, 389, 1997-2002. [CrossRef]

262. Nzoughet, J.K.; Campbell, K.; Barnes, P.; Cooper, K.M.; Chevallier, O.P.; Elliott, C.T. Comparison of sample preparation methods, validation of an UPLC-MS/MS procedure for the quantification of tetrodotoxin present in marine gastropods and analysis of pufferfish. Food Chem. 2013, 136, 1584-1589. [CrossRef] [PubMed]

263. Rodríguez, P.; Alfonso, A.; Otero, P.; Katikou, P.; Georgantelis, D.; Botana, L.M. Liquid chromatography-mass spectrometry method to detect Tetrodotoxin and Its analogues in the puffer fish Lagocephalus sceleratus [Gmelin, 1789] from European waters. Food Chem. 2012, 132, 1103-1111. [CrossRef]

264. Silva, M.; Azevedo, J.; Rodriguez, P.; Alfonso, A.; Botana, L.M.; Vasconcelos, V. New gastropod vectors and tetrodotoxin potential expansion in temperate waters of the Atlantic Ocean. Mar. Drugs 2012, 10, 712-726. [CrossRef] [PubMed] 
265. Yotsu-Yamashita, M.; Mebs, D.; Kwet, A.; Schneider, M. Tetrodotoxin and its analogue 6-epitetrodotoxin in newts [Triturus spp.; Urodela, Salamandridae] from southern Germany. Toxicon 2007, 50, 306-309. [CrossRef] [PubMed]

266. Hirata, Y.; Uemura, D.; Ohizumi, Y. Chemistry and pharmacology of palytoxin. In Handbook of Natural ToxinsVolume 3. Marine Toxins and Venoms; Tu, A.T., Ed.; Marcel Dekker, Inc.: New York, NY, USA; Basel, Switzerland, 1988.

267. Gleibs, S.; Mebs, D. Distribution and sequestration of palytoxin in coral reef animals. Toxicon 1999, 37, 1521-1527. [CrossRef]

268. Wiles, J.S.; Vick, J.A.; Christensen, M.K. Toxicological evaluation of palytoxin in several animal species. Toxicon 1974, 12, 427-433. [CrossRef]

269. CRLMB [Community Reference Laboratory for Marine Biotoxins]. Minutes of the 1st Meeting of Working Group on Toxicology of the National Reference Laboratories (NRLs) for Marine Biotoxins; CRLMB: Cesenatico, Italy, 2005.

270. Aligizaki, K.; Katikou, P.; Nikolaidis, G.; Panou, A. First episode of shellfish contamination by palytoxin-like compounds from Ostreopsis species [Aegean Sea, Greece]. Toxicon 2008, 51, 418-427. [CrossRef] [PubMed]

271. Bellocci, M.; Ronzitti, G.; Milandri, A.; Melchiorre, N.; Grillo, C.; Poletti, R.; Yasumoto, T.; Rossini, G.P. A cytolytic assay for the measurement of palytoxin based on a cultured monolayer cell line. Anal. Biochem. 2008, 374, 48-55. [CrossRef] [PubMed]

272. Riobó, P.; Paz, B.; Franco, J.M. Analysis of palytoxin-like in Ostreopsis cultures by liquid chromatography with precolumn derivatization and fluorescence detection. Anal. Chim. Acta 2006, 566, 217-223. [CrossRef]

273. Azevedo, S.M.F.O.; Carmichael, W.W.; Jochimsen, E.M.; Rinehart, K.L.; Lau, S.; Shaw, G.R.; Eaglesham, G.K. Human intoxication by microcystins during renal dialysis treatment in Caruaru—Brazil. Toxicology 2002, 181, 441-446. [CrossRef]

274. Kankaanpää, H.; Leiniö, S.; Olin, M.; Sjövall, O.; Meriluoto, J.; Lehtonen, K.K. Accumulation and depuration of cyanobacterial toxin nodularin and biomarker responses in the mussel Mytilus edulis. Chemosphere 2007, 68, 1210-1217. [CrossRef] [PubMed]

275. Sipiä, V.O.; Lahti, K.; Kankaanpää, H.T.; Vuorinen, P.J.; Meriluoto, J.A.O. Screening for cyanobacterial hepatotoxins in herring and salmon from the Baltic Sea. Aquat. Ecosyst. Health Manag. 2002, 5, 451-456. [CrossRef]

276. Zimba, P.V.; Camus, A.; Allen, E.H.; Burkholder, J.M. Co-occurrence of white shrimp, Litopenaeus vannamei, mortalities and microcystin toxin in a southeastern USA shrimp facility. Aquaculture 2006, 261, 1048-1055. [CrossRef]

277. Williams, D.E.; Craig, M.; Dawe, S.C.; Kent, M.L.; Holmes, C.F.B.; Andersen, R.J. Evidence for a covalently bound form of microcystin-LR in salmon liver and dungeness crab larvae. Chem. Res. Toxicol. 1997, 10, 463-469. [CrossRef]

278. Organization, W.H. Guidelines for Safe Recreational Water Environments: Coastal and Fresh Waters; World Health Organization, 2003; Volume 1. Available online: https:/ /www.who.int/water_sanitation_health/ publications/srwe1/en/ (accessed on 10 November 2018).

279. Cook, W.O.; Iwamoto, G.A.; Schaeffer, D.J.; Carmichael, W.W.; Beasley, V.R. Pathophysiologic Effects of Anatoxin-a [s] in Anaesthetized Rats: The Influence of Atropine and Artificial Respiration. Pharmacol. Toxicol. 1990, 67, 151-155. [CrossRef]

280. Patockaa, J.; Stredab, L. Brief review of natural nonprotein neurotoxins. ASA Newslett. 2002, 89, $16-24$.

281. Aráoz, R.; Nghiêm, H.-O.; Rippka, R.; Palibroda, N.; de Marsac, N.T.; Herdman, M. Neurotoxins in axenic oscillatorian cyanobacteria: Coexistence of anatoxin-a and homoanatoxin-a determined by ligand-binding assay and GC/MS. Microbiology 2005, 151, 1263-1273. [CrossRef]

282. Aráoz, R.; Vilariño, N.; Botana, L.M.; Molgó, J. Ligand-binding assays for cyanobacterial neurotoxins targeting cholinergic receptors. Anal. Bioanal. Chem. 2010, 397, 1695-1704. [CrossRef] [PubMed]

283. Serdula, M.; Bartolini, G.; Moore, R.E.; Gooch, J.; Wiebenga, N. Seaweed itch on windward Oahu. Hawaii Med. J. 1982, 41, 200-201. [PubMed]

284. Carmichael, W.W. Health effects of toxin-producing cyanobacteria: "The CyanoHABs”. Hum. Ecol. Risk Assess. 2001, 7, 1393-1407. [CrossRef]

285. Ito, E.; Nagai, H. Morphological observations of diarrhea in mice caused by aplysiatoxin, the causative agent of the red alga Gracilaria coronopifolia poisoning in Hawaii. Toxicon 1998, 36, 1913-1920. [CrossRef] 
286. Capper, A.; Tibbetts, I.R.; O'Neil, J.M.; Shaw, G.R. The fate of Lyngbya majuscula toxins in three potential consumers. J. Chem. Ecol. 2005, 31, 1595-1606. [CrossRef]

287. Nogle, L.M.; Okino, T.; Gerwick, W.H. Antillatoxin B, a Neurotoxic Lipopeptide from the Marine Cyanobacterium Lyngbya majuscula. J. Nat. Prod. 2001, 64, 983-985. [CrossRef] [PubMed]

288. Edwards, D.J.; Marquez, B.L.; Nogle, L.M.; McPhail, K.; Goeger, D.E.; Roberts, M.A.; Gerwick, W.H. Structure and biosynthesis of the jamaicamides, new mixed polyketide-peptide neurotoxins from the marine cyanobacterium Lyngbya majuscula. Chem. Biol. 2004, 11, 817-833. [CrossRef]

289. Griffiths, D.J.; Saker, M.L. The Palm Island mystery disease 20 years on: A review of research on the cyanotoxin cylindrospermopsin. Environ. Toxicol. 2003, 18, 78-93. [CrossRef]

290. Carmichael, W.W.; Azevedo, S.M.; An, J.S.; Molica, R.J.; Jochimsen, E.M.; Lau, S.; Rinehart, K.L.; Shaw, G.R.; Eaglesham, G.K. Human fatalities from cyanobacteria: Chemical and biological evidence for cyanotoxins. Environ. Health Perspect. 2001, 109, 663-668. [CrossRef]

291. Hawkins, P.R.; Chandrasena, N.R.; Jones, G.J.; Humpage, A.R.; Falconer, I.R. Isolation and toxicity of Cylindrospermopsis raciborskii from an ornamental lake. Toxicon 1997, 35, 341-346. [CrossRef]

292. Eaglesham, G.K.; Norris, R.L.; Shaw, G.R.; Smith, M.J.; Chiswell, R.K.; Davis, B.C.; Neville, G.R.; Seawright, A.A.; Moore, M.R. Use of HPLC-MS/MS to monitor cylindrospermopsin, a blue-green algal toxin, for public health purposes. Environ. Toxicol. 1999, 14, 151-154. [CrossRef]

293. Carson, B.; Masten, S. Cylindrospermopsin-Review of Toxicological Literature. Natl Inst Environ Heal Sci Res Triangle Park NC. 2000. Available online: https:/ /www.google.com.tw/url?sa=t\&rct=j\&q=\&esrc=s\&source= web\&cd=1\&cad=rja\&uact=8\&ved=2ahUKEwjkxOyK0_bfAhXTzmEKHRfwD7oQFjAAegQIBBAC\& url=https $\% 3 \mathrm{~A} \% 2 \mathrm{~F} \% 2$ Fntp.niehs.nih.gov $\% 2$ Fntp $\% 2$ Fhtdocs $\% 2$ Fchem_background $\% 2$ Fexsumpdf $\%$ 2Fcylindrospermopsin_508.pdf\&usg=AOvVaw3_GiX62TnUp4LKIDO6z2Me（accessedｏn 10 November 2018).

294. Blahova, L.; Oravec, M.; Maršálek, B.; Šejnohova, L.; Šimek, Z.; Bláha, L. The first occurrence of the cyanobacterial alkaloid toxin cylindrospermopsin in the Czech Republic as determined by immunochemical and LC/MS methods. Toxicon 2009, 53, 519-524. [CrossRef] [PubMed]

295. Dale, B. Marine dinoflagellate cysts as indicators of eutrophication and industrial pollution: A discussion. Sci. Total Environ. 2001, 264, 235-240. [CrossRef]

296. Hallegraeff, G.M. Harmful algal blooms: A global overview. Man Harmful Mar. Microalgae 2003, 33, 1-22.

297. Bragadeeswaran, S.; Therasa, D.; Prabhu, K.; Kathiresan, K. Biomedical and pharmacological potential of tetrodotoxin-producing bacteria isolated from marine pufferfish Arothron hispidus [Muller, 1841]. J. Venom. Anim. Toxins Incl. Trop. Dis. 2010, 16, 421-431. [CrossRef]

298. Bubb, H.D. Vibrio parahaemolyticus-a marine pathogen detected in South African coastal waters. S. Afr. Med. J. 1975, 49, 1514-1516. [PubMed]

299. Abd-Elghany, S.M.; Sallam, K.I. Occurrence and molecular identification of Vibrio parahaemolyticus in retail shellfish in Mansoura, Egypt. Food Control 2013, 33, 399-405. [CrossRef]

300. Jean Turquet, J.-P.Q.; Ten-Hage, L.; Dahalani, Y.; Wendling, B. Example of a Gambierdiscus toxicus flare-up following the 1998 coral bleaching event in Mayotte Island [Comoros, south-west Indian Ocean]. In Proceedings of the 9th International Conference on Harmful Algae, Hobart, Tasmania, 7-11 February 2000.

301. Kiteresi, L.; Mwangi, S.; Mary, M. Potentially Harmful Algae along the Kenyan Coast: A Norm or Threat. Harmful Algae 2013, 3.

302. Silva, S.M.F.; Pienaar, R.N. Marine Cyanophytes from the Western Cape, South Africa: Chroococcales. S. Afr. J. Bot. 1999, 65, 32-49. [CrossRef]

303. Shibl, A.A.; Thompson, L.R.; Ngugi, D.K.; Stingl, U. Distribution and diversity of Prochlorococcus ecotypes in the Red Sea. FEMS Microbiol. Lett. 2014, 356, 118-126. [CrossRef]

304. Zubia, M.; Turquet, J.; Golubic, S. Benthic cyanobacterial diversity of iles eparses [Scattered islands] in the Mozambique channel. Acta Oecol. 2016, 72, 21-32. [CrossRef]

305. Van der Molen, J.S.; Scharler, U.M.; Muir, D. Species composition, abundance and biomass of microphytoplankton in the KwaZulu-Natal Bight on the east coast of South Africa. Afr. J. Mar. Sci. 2016, 38, S139-S153. [CrossRef]

306. Grindley, J.R.; Taylor, F.J.R.; Day, J.H. Red water and marine fauna mortality near Cape Town. Trans. R. Soc South Africa. 1964, 37, 111-130. [CrossRef] 
307. Silva, S.M.F.; Pienaar, R.N. Epipelic marine Cyanophytes of Bazaruto Island, lnhambane, Mozambique. S. Afr. J. Bot. 1997, 6, 459-464. [CrossRef]

308. Sadally, S.B.; Taleb-Hossenkhan, N.; Bhagooli, R. Spatio-temporal variation in density of microphytoplankton genera in two tropical coral reefs of Mauritius. Afr. J. Mar. Sci. 2014, 36, 423-438. [CrossRef]

309. Pitcher, G.C.; Cembella, A.D.; Joyce, L.B.; Larsen, J.; Probyn, T.A.; Sebastián, C.R. The dinoflagellate Alexandrium minutum in Cape Town harbour [South Africa]: Bloom characteristics, phylogenetic analysis and toxin composition. Harmful Algae 2007, 6, 823-836. [CrossRef]

310. Ochieng, O.B.; Khakasa, M.K.; Sturcky, O.P. Harmful marine phytoplankton community in Shirazi Creek, Kenya. J. Fish. Aquat. Sci. 2015, 10, 266-275. [CrossRef]

311. Nassar, M.Z.; El-Din, N.G.S.; Gharib, S.M. Phytoplankton variability in relation to some environmental factors in the eastern coast of Suez Gulf, Egypt. Environ. Monit. Assess. 2015, 187, 648. [CrossRef]

312. Olofsson, M.; Karlberg, M.; Lage, S.; Ploug, H. Phytoplankton community composition and primary production in the tropical tidal ecosystem, Maputo Bay [the Indian Ocean]. J. Sea Res. 2017, 125, 18-25. [CrossRef]

313. Sá, C.; Leal, M.C.; Silva, A.; Nordez, S.; André, E.; Paula, J.; Brotas, V. Variation of phytoplankton assemblages along the Mozambique coast as revealed by HPLC and microscopy. J. Sea Res. 2013, 79, 1-11. [CrossRef]

314. Riaux-Gobin, C.; Compère, P. Olifantiella mascarenica gen. \& sp. nov., a new genus of pennate diatom from Réunion Island, exhibiting a remarkable internal process. Phycol. Res. 2009, 57, 178-185.

315. Quod, J.P.; Turquet, J.; Diogene, G.; Fessard, V. Screening of extracts of dinoflagellates from coral reefs [Reunion Island, SW Indian Ocean], and their biological activities. Harmful Mar. Algal Bloom. 1995, 815-820.

316. El Semary, N. Benthic dinoflagellates from Red Sea, Egypt: Early records. Egypt. J. Aquat. Res. 2016, 42, 177-184. [CrossRef]

317. Berland, B.; Grzebyk, D.; Thomassin, B.-A. Benthic dinoflagellates from the coral reef lagoon of Mayotte Island [SW Indian Ocean]; identification, toxicity and preliminary ecophysiological study. Bull. Pathol. Exot. 1992, 85, 453-456.

318. Burckle, L.H. Distribution of diatoms in sediments of the northern Indian Ocean: Relationship to physical oceanography. Mar. Micropaleontol. 1989, 15, 53-65. [CrossRef]

319. Carnicer, O.; Tunin-Ley, A.; Andree, K.B.; Turquet, J.; Diogène, J.; Fernández-Tejedor, M. Contribution to the genus Ostreopsis in Reunion Island [Indian Ocean]: Molecular, morphologic and toxicity characterization. Cryptogam. Algol. 2015, 36, 101-119. [CrossRef]

320. Janse van Vuuren, S.; Taylor, J.C. Changes in the algal composition and water quality of the Sundays River, Karoo, South Africa, from source to estuary. Afr. J. Aquat. Sci. 2015, 40, 339-357. [CrossRef]

321. Alkawri, A.; Abker, M.; Qutaei, E.; Alhag, M.; Qutaei, N.; Mahdy, S. The first recorded bloom of Pyrodinium bahamense var bahamense plate in Yemeni coastal waters off Red Sea, near Al Hodeida City. Turkish. J. Fish. Aquat. Sci. 2016, 16, 275-282.

322. Alkawri, A. Seasonal variation in composition and abundance of harmful dinoflagellates in Yemeni waters, southern Red Sea. Mar. Pollut. Bull. 2016, 112, 225-234. [CrossRef]

323. Ten-Hage, L.; Quod, J.-P.; Turquet, J.; Couté, A. Bysmatrum granulosum sp. nov., a new benthic dinoflagellate from the southwestern Indian Ocean. Eur.J. Phycol. 2001, 36, 129-135. [CrossRef]

324. Africa D of AF and F of R of S. South African Molluscan Shellfish Monitoring \& Control Programme; Cape Town, 2016. Available online: https:/ $/$ www.google.com.tw / url?sa=t\&rct=j\&q=\&esrc=s\&source=web\&cd=2\& ved=2ahUKEwjZrIjL4fbfAhVCA4gKHdB_C8QQFjABegQIBRAE\&url=https\%3A\%2F\%2Fwww.nda.agric. za\%2Fdoadev\%2Fsidemenu\%2Ffisheries\%2F03_areasofwork\%2FAquaculture\%2FSAMSMCP\%2F2011\% 2520SMP\%2520Report.pdf\&usg=AOvVaw0Czyg63VGGS5rcLw9oMzot (accessed on 10 November 2018).

325. Tanzania Food and Drugs Authority. Guidelines for Investigation and Control of Foodborne Diseases; Dar Es Salaam, 2011. Available online: http:/ /apps.who.int/iris/handle/10665/43771 (accessed on 10 November 2018).

326. Munga, D.; Bosire, J.O.; Ruwa, R.K.; Jembe, T.; Abila, R.O.; Gichuki, J.W. Kenya Marine and Fisheries Research Institute Research Policy. 2010. Available online: https://www.unenvironment.org/nairobiconvention/ kenya-marine-and-fisheries-research-institute-kmfri (accessed on 20 June 2018).

327. Cato, J.C. Seafood Safety: Economics of Hazard Analysis and critical Control Point (HACCP) Programmes; Food \& Agriculture Org.: Rome, Italy, 1998. 
328. Bouarcha, N.; Chézeau, A.; Turquet, J.; Quod, J.-P.; Puiseux-Dao, S. Morphological and toxicological variability of Prorocentrum lima clones isolated from four locations in the south-west Indian Ocean. Toxicon 2001, 39, 1195-1202. [CrossRef]

329. El Masry, M.K.; Tawfik, H.M. 2011 Annual Report of the Poison Control Centre of Ain Shams University Hospital, Cairo, Egypt. Ain-Shams J. Forensic. Med. Clin. Toxicol. 2013, 20, 10-17. [CrossRef]

330. Sector, N.C. Biodiversity conservation capacity building in Egypt. 2006. Available online: https: / / www.google.com.tw / url?sa=t\&rct=j\&q=\&esrc=s\&source=web\&cd=1\&ved=2ahUKEwiGwcLZ1_ bfAhXWfd4KHZC-AbkQFjAAegQIABAC\&url=https $\% 3 \mathrm{~A} \% 2 \mathrm{~F} \% 2 \mathrm{Fwww.cbd} . i n t \% 2 \mathrm{Fdoc} \% 2 \mathrm{Fpa} \%$ 2Ftools\%2FBiodiversity\%2520conservation\%2520capacity\%2520planning\%2520in\%2520Egypt.pdf\& usg=AOvVaw0jMs0RyUh5bG6FjHKTn1Mw (accessed on 10 November 2018).

331. Joyce, L.B.; Pitcher, G.C.; Du Randt, A.; Monteiro, P.M.S. Dinoflagellate cysts from surface sediments of Saldanha Bay, South Africa: An indication of the potential risk of harmful algal blooms. Harmful Algae 2005, 4, 309-318. [CrossRef]

332. Matthews, M.W.; Bernard, S. Eutrophication and cyanobacteria in South Africa's standing water bodies: A view from space. S. Afr. J. Sci. 2015, 111, 1-8. [CrossRef]

333. Kopczyńska, E.E.; Fiala, M. Surface phytoplankton composition and carbon biomass distribution in the Crozet Basin during austral summer of 1999: Variability across frontal zones. Polar Biol. 2003, 27, 17-28. [CrossRef]

334. Sebastián, C.R.; Etheridge, S.M.; Cook, P.A.; O'ryan, C.; Pitcher, G.C. Phylogenetic analysis of toxic Alexandrium [Dinophyceae] isolates from South Africa: Implications for the global phylogeography of the Alexandrium tamarense species complex. Phycologia 2005, 44, 49-60. [CrossRef]

335. Bauer, K.; Díez, B.; Lugomela, C.; Seppälä, S.; Borg, A.J.; Bergman, B. Variability in benthic diazotrophy and cyanobacterial diversity in a tropical intertidal lagoon. FEMS Microbiol. Ecol. 2008, 63, 205-221. [CrossRef] [PubMed]

336. Díez, B.; Nylander, J.A.A.; Ininbergs, K.; Dupont, C.L.; Allen, A.E.; Yooseph, S.; Rusch, D.B.; Bergman, B. Metagenomic analysis of the Indian ocean picocyanobacterial community: Structure, potential function and evolution. PLoS ONE 2016, 11, e0155757. [CrossRef] [PubMed]

337. Hamisi, M.I.; Mamboya, F.A. Nutrient and phytoplankton dynamics along the ocean road sewage discharge channel, Dar es Salaam, Tanzania. J. Ecosyst. 2014, 2014, 271456. [CrossRef]

338. Kyewalyanga, M.; Lugomela, C. Existence of potentially harmful microalgae in coastal waters around Zanzibar: A need for a monitoring programme? 1999. Available online: https:/ / www.researchgate.net/publication/266872736_Existence_of_potentially_harmful_microalgae_in_ coastal_waters_around_Zanzibar_A_need_for_a_monitoring_programme (accessed on 10 June 2018).

339. Lugomela, C.; Pratap, H.B.; Mgaya, Y.D. Cyanobacteria blooms-A possible cause of mass mortality of Lesser Flamingos in Lake Manyara and Lake Big Momela, Tanzania. Harmful Algae 2006, 5, 534-541. [CrossRef]

340. Lugomela, C. Population dynamics of Pseudo-nitzschia species [bacillariophyceae] in the near shore waters of Dar es Salaam, Tanzania. Tanzan. J. Sci. 2013, 39, 38-48.

341. Lundgren, P.; Bauer, K.; Lugomela, C.; Söderbäck, E.; Bergman, B. Reevaluation of the nitrogen fixation behavior in the marine non-heterocystous cyanobacterium Lyngbya majuscula. J. Phycol. 2003, 39, 310-314. [CrossRef]

342. Kotut, K.; Ballot, A.; Krienitz, L. Toxic cyanobacteria and their toxins in standing waters of Kenya: Implications for water resource use. J. Water Health 2006, 4, 233-245. [CrossRef]

343. Robinson, R.; Champetier de Ribes, G.; Ranaivoson, G.; Rejely, M.; Rabeson, D. KAP study [knowledge-attitude-practice] on seafood poisoning on the southwest coast of Madagascar. Bull. Soc. Pathol. Exot. 1999, 92, 46-50. [PubMed]

344. Diogène, J.; Campàs, M. Recent Advances in the Analysis of Marine Toxins; Elsevier: Centro Rio de Janeiro, Brazil, 2017; Volume 78.

345. Grzebyk, D.; Berland, B.; Thomassin, B.A.; Bosi, C.; Arnoux, A. Ecology of ciguateric dinoflagellates in the coral reef complex of Mayotte Island [SW Indian Ocean]. J. Exp. Mar. Biol. Ecol. 1994, 178, 51-66. [CrossRef]

346. Glaizal, M.; Tichadou, L.; Drouet, G.; Hayek-Lanthois, M.; De Haro, L. Ciguatera contracted by French tourists in Mauritius recurs in Senegal. Clin. Toxicol. 2011, 49, 767. [CrossRef] [PubMed]

347. ISO. IEC 17025: 2005 General Requirements for the Competence of Testing and Calibration Laboratories; ICS: Geneva, Switzerland, 2005; p. 20. 
348. Ministery of Ocean, Economy, Marine Resources, Shipping F and Annual Report on Performance Fiscal Year 2016/17. 2017. Available online: http://amb.intnet.mu/English/Documents/AnnualReports/ AMBANNUALREPORT2012-2013.pdf (accessed on 10 November 2018).

349. Banguera-Hinestroza, E.; Eikrem, W.; Mansour, H.; Solberg, I.; Cúrdia, J.; Holtermann, K.; Edvardsen, B.; Kaartvedt, S. Seasonality and toxin production of Pyrodinium bahamense in a Red Sea lagoon. Harmful Algae 2016, 55, 163-171. [CrossRef]

350. Catania, D.; Richlen, M.L.; Mak, Y.L.; Morton, S.L.; Laban, E.H.; Xu, Y.; Anderson, D.M.; Chan, L.L.; Berumen, M.L. The prevalence of benthic dinoflagellates associated with ciguatera fish poisoning in the central Red Sea. Harmful Algae 2017, 68, 206-216. [CrossRef]

351. Sabrah, M.M.; El-Ganainy, A.A.; Zak Cembella, A.D.; Lewis, N.I.; Quilliam, M.A. The marine dinoflagellate Alexandrium ostenfeldii (Dinophyceae) as the causative organism of spirolide shellfish toxins. Phycologia 2000, 39, 67-74.

352. Lopez, J.A.V.; Al-Lihaibi, S.S.; Alarif, W.M.; Abdel-Lateff, A.; Nogata, Y.; Washio, K.; Morikawa, M.; Okino, T. Wewakazole B, a Cytotoxic Cyanobactin from the Cyanobacterium moorea producens Collected in the Red Sea. J. Nat. Prod. 2016, 79, 1213-1218. [CrossRef]

353. Mohamed, Z.A.; Al-Shehri, A.M. Occurrence and germination of dinoflagellate cysts in surface sediments from the Red Sea off the coasts of Saudi Arabia. Oceanologia 2011, 53, 121-136. [CrossRef]

354. Abd-Elhaleem, Z.A.; Abd-Elkarim, M.A. Pattern of food poisoning in Egypt, a retrospective study. J. Pharmacol. Toxicol. 2011, 6, 505-515. [CrossRef]

(C) 2019 by the authors. Licensee MDPI, Basel, Switzerland. This article is an open access article distributed under the terms and conditions of the Creative Commons Attribution (CC BY) license (http://creativecommons.org/licenses/by/4.0/). 